UNIVERSIDADE DE SÃO PAULO

FACULDADE DE FILOSOFIA, LETRAS E CIÊNCIAS HUMANAS DEPARTAMENTO DE LETRAS ORIENTAIS

PROGRAMA DE PÓS-GRADUAÇÃO EM LITERATURA E CULTURA RUSSA

PAULA COSTA VAZ DE ALMEIDA

O Meu Púchkin

de Marina Tsvetáieva: tradução e apresentação

SÃO PAULO

2008 
UNIVERSIDADE DE SÃO PAULO

FACULDADE DE FILOSOFIA, LETRAS E CIÊNCIAS HUMANAS

DEPARTAMENTO DE LETRAS ORIENTAIS

PROGRAMA DE PÓS-GRADUAÇÃO EM LITERATURA E CULTURA

RUSSA

O Meu Púchkin de Marina Tsvetáieva: tradução e apresentação

Paula Costa Vaz de Almeida

Dissertação apresentada junto à área de Literatura e Cultura Russa da Faculdade de Filosofia, Letras e Ciências Humanas da Universidade de São Paulo, com vista à obtenção do título de Mestre em Letras.

Orientador: Prof. Dr. Homero Freitas de Andrade

São Paulo 
Para

Levy, Regina,

Elizabeth, Edson

Maryana e Matheus

Euclides Costa (in memoriam) 
Agradecimentos especiais a

Prof. Dr. Homero Freitas de Andrade Prof ${ }^{a}$. Dra. Salete Cara Prof. Dr. Ariovaldo José Vidal

Dra. Ana Paula Freitas de Andrade Ekaterina Volkova Américo

Capes

(Coordenação de Aperfeiçoamento de Pessoal de Nível Superior) 


\section{Resumo}

Este trabalho é composto pela tradução anotada do ensaio Мой Пушкин (Meu Púchkin, 1937), da poeta russa Marina Tsvetáieva, bem como por uma apresentação da obra em prosa da autora, de um modo geral, e do ensaio $\mathrm{Meu}$ Púchkin, em particular. Para tanto apontaremos seus principais procedimentos compositivos à luz de Mikhail Bakhtin, Tzvetan Todorov, Elisabeth Burgos, entre outros.

\section{Palavras-chave}

- Marina Tsvetáieva;

- Meu Púchkin;

- Aleksandr Serguéievitch Púchkin;

- Poesia russa;

- Literatura autobiográfica;

- Poesia russa do século XX. 


\section{Abstract}

This research is composed by twou parts: a commented translation of the russian poet Marina Tsvetayeva's essay Мой Пушкин (My Pushkin, 1937) and a presentation of her prose literary production, in a general way, as well as a particular focus on My Pushkin essay. To accomplish this task, the main compositive procedures have been pointed out in the light of Mikhail Bakhtin, Tzvetan Todorov, Elisabeth Burgos and other author's view.

\section{Key words}

- Marina Tsvetayeva;

- My Pushkin;

- Aleksandr Sergueievitch Pushkin;

- Russian poetry;

- Authobiographic literature;

- 20th century russian poetry. 


\section{Índice}

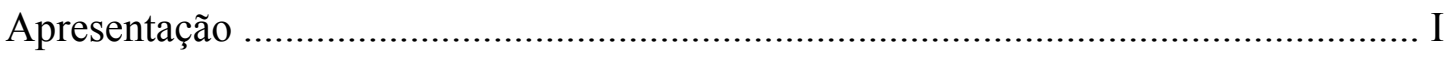

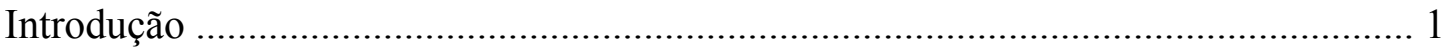

Nota geral à tradução ………………………………………………………….... 32

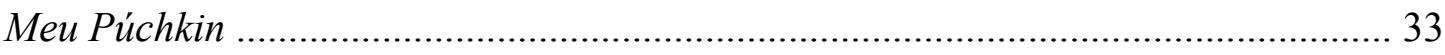

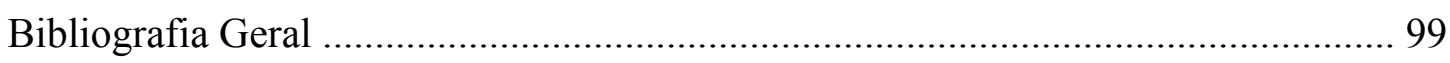

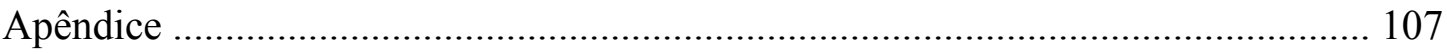




\section{Apresentação}

O centro deste estudo será a tradução direta do ensaio em prosa de Marina Tsvetáieva Meu Púchkin (Мой Пушкин, 1937), que contará com notas explicativas sobre a história e a cultura russa, fatos das biografias de Púchkin e de Tsvetáieva, e informações acerca das poesias de Púchkin citadas pela autora. Além disso, faz parte desta pesquisa, uma introdução, que busca contemplar aspectos da vida e da obra de Marina Tsvetáieva, com ênfase para sua produção em prosa, em que o ensaio Meu Púchkin é o principal foco e ponto de partida. ${ }^{1}$

Para tanto, foi fundamental a leitura das obras de Marina Tsvetáieva² . Com relação aos ensaios, destacam-se aqueles escritos no período em que a poeta viveu na França, especialmente, os ensaios autobiográficos $O$ diabo, (Чepm, 1935) е Mamãe e a música (Мать и Музыка, 1935), bem como o ensaio de crítica literária O poeta e o teтро (Поэт и время, 1932), pois tais obras, do ponto de vista da temática, podem ser consideradas complementares ao ensaio Meu Púchkin. Já no que se refere à poética, concentrou-se, sobretudo, nos poemas que Tsvetáieva dedicou a Aleksandr Sergueiévitch Púchkin (1799-1837), com especial atenção aos pertencentes ao ciclo Poemas a Púchkin (Смихи к Пушкину, 1931), uma vez que este foi escrito na década de 1930 e faz parte dos trabalhos produzidos por ocasião do centenário da morte do poeta. Destaca-se, ainda, a leitura das cartas escritas nos anos de 1930 e endereçadas à escritora tcheca

\footnotetext{
${ }^{1} \mathrm{O}$ presente ensaio, bem como toda a produção em prosa de Marina Tsvetáieva, é inédita no Brasil. Já no âmbito da poesia, encontram-se publicados Indícios flutuantes, com tradução e seleção de poemas de Aurora Bernardini, e algumas poemas traduzidos por Aroldo de Campos, Augusto de Campos e Boris Schnaiderman e publicados na coletânea Poesia russa moderna.

${ }^{2}$ Cf. ver item 3.1 da Bibliografia Geral.
} 
Anna Teskova (1872-1954), bem como os trechos de seu diário reunidos e comentados por Tzvetan Todorov em livro intitulado Vivendo sob o fogo.

Do ponto de vista teórico, sobre a poética de Marina Tsvetáieva, destacamse as questões levantadas por Aurora Fornoni Bernardini em sua tese de livredocência Indícios flutuantes em Marina Tsvetáieva; ao passo que naquilo que tange a prosa, recorreu-se em grande parte à análise feita por Elizabeth Burgos no prefácio à sua tradução para o espanhol do ensaio "Carta a la Amazona" (Mon frère féminin: Lettre à l'Amazone, 1932), escrita originalmente em francês. No que diz respeito à vida da poeta, as principais fontes para esta pesquisa foram Vivendo sob o fogo, traduzido do russo e do francês para o português por Aurora Bernardini, e a tradução francesa da biografia elaborada por Maria Belkina, Le destin tragique de Marina Tsvetáieva. Finalmente, com relação à vida e obra de Púchkin, além das leituras dos poemas citados por Tsvetáieva no ensaio Meu Púchkin, apresenta-se como fonte indispensável o Dossiê Púchkin, organizado por Homero Freitas de Andrade e publicado no Caderno de Literatura e Cultura Russa, do Curso de Russo da USP.

Por fim, cabe dizer que no apêndice deste trabalho, a título de informações complementares, foram inseridos um índice de nomes e referências que aparecem no ensaio Meu Púchkin, uma cronologia da vida de Marina Tsvetáieva e uma seleção dos poemas de Púchkin que aparecem no ensaio, em traduções para o inglês e o espanhol. 


\section{Introdução}

Do "Meu Púchkin"

"Tudo o que eu amei, amei antes dos sete, depois, nada mais. Aos 47 anos posso dizer que tudo o que eu viria a conhecer, conheci antes dos sete, depois, só tomei consciência.”

(Marina Tsvetáieva, Autobiografia, 1939) ${ }^{3}$

Para escrever o ensaio Meu Púchkin (Мой Пушкин, 19374), a poeta russa Marina Tsvetáieva (1892-1941) apoiou-se em sua experiência de vida, relatando suas primeiras impressões, até os sete anos de idade, sobre aquele que é considerado o maior poeta e fundador da literatura russa moderna. Trata-se de um ensaio de reminiscências líricas e subjetivas, com elementos de crítica literária. Nele, Tsvetáieva recria o seu mundo infantil e vale-se de A. S. Púchkin não apenas como pretexto para reconstituir o seu passado, mas, ainda, como artifício para preencher lacunas de sua memória. Em Meu Púchkin, o poeta cumpre a função de elo com o passado, pois é justamente através dele que a autora resgata a sua infância e a sua formação como poeta.

\footnotetext{
${ }^{3}$ Vivendo sob o fogo, p. 81.

${ }^{4} \mathrm{O}$ texto foi redigido ao longo de 1936, mas só foi concluído nos primeiros dias de 1937. Em carta a Anna Teskova de 2 janeiro de 1937, Marina Tzvetáieva conta: "assim que levantei da gripe, sentei e passei a limpo de uma só vez a minha prosa Meu Púchkin". (In.: ЦBETAEBA, М. И., Собрание сочинений: В 7 m. Том 6, 447c./TSVETÁIEVA, M. I., Obras completas em $7 t$. Tomo 6, p. 447.). Os trechos das obras completas citados neste trabalho foram retirados do sítio da internet www.tsvetayeva.com, cuja fidelidade em relação ao original pôde ser comprovada em comparação com as Obras Completas da poeta pertencentes ao acervo do Museu Marina Tsvetáieva, de Moscou. A partir de agora, usaremos para citá-las apenas "CC". Todas as citações de "CC" utilizadas neste trabalho foram traduzidas diretamente do russo.
} 
No ensaio emprega-se a técnica narrativa da memorialística, e, desse modo, Tsvetáieva figura como autora e personagem da obra. O tempo da narração é o presente, mas o tempo narrado é o passado. $\mathrm{Na}$ posição de personagem, encontra-se a criança, que pertence ao tempo narrado e é representada nas formas do pretérito. Na posição de autora, a adulta, que escreve no tempo presente e tem uma relação complexa com a obra, uma vez que as fronteiras entre autor-criador (elemento da obra) e autor-pessoa (elemento da realidade como tal) são enfraquecidas ${ }^{5}$. Disso resulta um entrecruzamento de planos temporais que reflete diretamente no plano da narrativa: Púchkin é ao mesmo tempo tema e protagonista.

O poeta morto diante de seus olhos, no quadro de Naúmov que ficava no quarto da mãe, é "o arrastado". O poeta de todas as Rússias é o primeiro de Tsvetáieva. O mito que, para ela, determina uma escolha: “defender o poeta do resto, pouco importando como se vistam ou se chamem”. Púchkin é ainda o "Monumento-de-Púchkin", o mestre de suas primeiras lições: números, proporções, matérias, hierarquia, idéia e o principal: "de mil bonequinhas ainda que empilhadas uma sobre a outra, não se faz um Púchkin”.

O monumento a Púchkin em Moscou, o poeta negro do bulevar Tvier, fundido em ferro, é "o fato que derruba a teoria". Antes que alguém o dissesse, o monumento já havia dito a Tsvetáieva que Púchkin era negro, que todo poeta era negro e que o poeta-negro era russo. E "como se é obrigado a escolher",

\footnotetext{
${ }^{5}$ Cf. Estética da criação verbal, cit.

${ }^{6}$ Todas as citações que aparecem nesta Introdução sem referência bibliográfica em nota de rodapé foram extraídas da tradução do russo para o português do ensaio Meu Púchkin que faz parte deste trabalho.
} 
escolheu-se para sempre: “o negro e não o branco, o preto e não o branco: pensamentos negros, destino negro, vida negra”.

A compreensão do destino da poesia russa, bem como do lugar que ambos nela ocupam, faz Tsvetáieva dedicar-se ao tema da vida e da obra de Púchkin. Às vésperas do centenário de sua morte (em 1837 por ocasião de um duelo com o barão George-Charles D'Anthès ${ }^{7}$ ), a crítica soviética oficial insistia em referir a atualidade do escritor e de sua obra; ao passo que os russos emigrados da URSS tomavam-nos como símbolos dos velhos tempos. Marina Tsvetáieva cria um Púchkin que resiste a ambos os campos, pois ela destaca a liberdade ideológica de sua personalidade, e vê na sua poesia o princípio e a força da libertação. De acordo com tal convicção, o poeta é filho da natureza, e esta, por sua vez, sempre se revolta contra tudo que está prensado, petrificado, ou que tenha passado de seu tempo. Em carta a Anna Teskova, Tsvetáieva afirma que o seu Púchkin é “a vingança do poeta através da poeta”, pois representa um "desafio individual, da poeta para os hipócritas de ontem e hoje" ${ }^{\text {. }}$.

No ensaio, Tsvetáieva cria um jogo de espelhamentos entre a vida e a obra do poeta e a sua própria história. Para ela, a infância é o período de gestação do resto da sua vida, que, aos poucos, vai se revelando. Assim, ao

\footnotetext{
7 “O encontro de Púchkin e D'Anthès, acompanhados dos respectivos padrinhos, dá-se por volta das cinco horas da tarde, num campo nevado nos arredores de Petersburgo. D'Anthès atira primeiro e acerta o poeta no ventre. Púchkin tomba sobre a neve. Ergue-se a custo e dispara por sua vez, acertando D'Anthès no braço. Ferido mortalmente, o Poeta é levado para casa. Chegam os amigos que se revezam à sua cabeceira. Púchkin não acredita que o ferimento seja mortal, apesar das dores atrozes que o fazem perder a consciência a todo instante. Nicolau I envia-lhe uma carta. O Poeta lê, mas seu conteúdo permanece desconhecido até hoje. Petersburgo em peso coloca-se diante da casa do Poeta, rezando por seu restabelecimento. Não são aristocratas, não são cortesãos. É o povo simples. Aleksandr Serguéievitch morre às $2 \mathrm{~h} 45$ de 29 de janeiro." (Cronologia da vida e da obra de A. S. Púchkin. In.: Caderno de literatura e cultura russa, p. 137).

8 "CC", p. 448.
} 
voltar ao Púchkin da sua infância, a autora reconhece não apenas o mestre das primeiras lições, mas também um oráculo. Para ela, Púchkin foi imagem, antes de ser palavra. Antes de seus versos, o monumento e o quadro haviam lhe ensinado que todo poeta era negro e estava morto.

A repetição insistente do nome de Púchkin no ensaio deixa entrever a dualidade que se desenha desde o primeiro parágrafo:

Este começo é como um capítulo do romance de cabeceira de todas as nossas mamães e vovós - "Jane Eyre" - O segredo do quarto vermelho. No quarto vermelho havia um armário secreto.

Neste armário vivia Púchkin ${ }^{9}$. O poeta envolvido na história do segredo do quarto vermelho é um artifício usado pela autora para esconder o seu próprio rosto e anunciar a revelação que se daria através de Púchkin, poema a poema. Tsvetáieva evoca Púchkin, e, com isso, desloca a imagem do poeta para o centro da história, desviando de si o foco narrativo. Há nisso algo da estética clássica, que incita o leitor, deixando-o intrigado, uma vez que a autora retarda a revelação da história secreta do quarto vermelho.

Depois de chamar a atenção para o Púchkin mítico de sua infância, a poeta revela:

\footnotetext{
${ }^{9}$ No parágrafo de abertura de Os diabos, ensaio autobiográfico de 1935, Marina Tsvetáieva escreve: "O Diabo vivia nos aposentos de minha irmã Valiéria". E algumas páginas depois: "Quando o Diabo chegou aos aposentos de Valiéria, chegou a um lugar já pronto: o do meu crime e o da proibição materna (...) Nos aposentos de Valiéria, antes de fazer sete anos, de tempos em tempos, com os olhos e os ouvidos atentos à mamã, li Eugénio Oneguine, Mazeppa, Ondina, A camponesa, Os ciganos." (O Diabo, pp. 23 e 30. In: TSVIETAIEVA, Marina. $O$ diabo. Tradução de Manuel Dias. Relógio d’Água: Lisboa, 1994)
} 
Ah, a casa toda era misteriosa, a casa todinha era um mistério! $\mathrm{O}$ armário proibido. O fruto proibido. Este fruto - um volume, um enorme volume azul-violeta com letras douradas na diagonal - Obras Completas de A. S. Púchkin.

No quarto da irmã Valiéria, às escondidas, "mergulhada no armário, quase metida no livro e na prateleira", Marina Tsvetáieva leu Os $\operatorname{ciganos}^{10}$, seu primeiro Púchkin e seu primeiro amor; e também o romance em versos Evguéni Oniéguin ${ }^{11}$, que, para ela, representou tanto uma condenação: “eu não quis mais ser feliz e me condenei ao - não-amor", quanto uma condição: "se não existisse a Tatiana ${ }^{12}$ de Púchkin - não existiria eu".

Em oposição a este Púchkin-secreto, surgiu o Púchkin-revelado, "das edições para as escolas municipais". Nele, até Os ciganos e Evguéni Oniéguin eram diferentes. Trata-se de um Púchkin de cartilha, domesticado, de cativeiro. Em suas leituras secretas ela havia aprendido, com o fim trágico da cigana Zemfira e a história do "não-amor" da pobre Tatiana, que o amor não é feliz; mas, nos versos do livrinho escolar, deparou-se justamente com o oposto. Por fim, essa cartilha foi abandonada, pois além de não despertar o amor, era leve demais, se comparada ao denso volume azul-violeta do armário secreto. Já a antologia de poemas pertencente ao irmão Andrei, a despeito de ser permitida, pois "nada tinha de prematura", era amada por ela. Ali, a criança podia não apenas ler, "mas também estudar, e copiar, e

\footnotetext{
${ }^{10}$ Цыганы (1825).

${ }^{11}$ Евгений Онегин (1823-1830).

${ }^{12}$ Heroína do romance citado.
} 
compor com as próprias palavras". Este é o Púchkin que as perguntas e as explicações óbvias da mãe impediam de imaginar. "Mas, por sorte, mamãe nem sempre fazia perguntas e alguns versos permaneciam compreensíveis".

A antologia trazia, entre outras coisas, o Púchkin dos poemas históricos - Poltava, O banquete de Pedro I e Delibach. Com os poemas líricos (e de terror) Os afogados, Vurdalak e Os diabos aprendeu sobre paixão e piedade; com $\grave{A} a m a$, sobre solidão e amizade. Todos esses e $A o m_{a r}^{13}$ revelaram-lhe que ela também era poeta.

“Ao Mar.

Passei o verão de 1902 inteiro a copiá-lo da antologia num livrinho que eu mesma fiz. Por que num livrinho se tem na antologia? Para levar sempre comigo no bolso, para passear com o Mar no Patchov e nos cepinhos, para que fosse mais-meu, para que eu mesma escrevesse."

A criança, que antes furtara poemas de Púchkin dos livros de Valiéria e Andrei, furtava então a obra ao poeta. Ela faz de conta que é a autora de $A o$ mar, e, em seguida, escreve o poema "Com uma lasca de rocha no rochedo", no qual a narradora, em um processo de auto-revelação, funde-se de vez com Púchkin, para representar o próprio nascimento como poeta.

A pequena Marina apropria-se de Ao mar. Com isso, busca atingir o absoluto da criação, e desnuda-se diante do leitor. Do ponto de vista estético, a

\footnotetext{
${ }^{13}$ Respectivamente: Полтава (1828-1829), Пир Петра Первого (1835), Делибаш (1829), Утопленник (1828), Вурдалак (1835), Бесы (1830), К няне (1826) е К морю (1824).
} 
autora define-se como personagem de si mesma, construída a partir da sua transmutação em Púchkin, no âmbito do fato narrado. Os duplos criança e poeta, autora e personagem, Tsvetáieva e Púchkin, que se desenhavam até então, encerram-se no momento em que a criança, "apenas dando as costas ao mar verdadeiro", reconstrói com "branco sobre cinza, ardósia sobre ardósia" o poema de Púchkin. E, antes que a onda venha, ela ainda tem tempo de assinar: Aleksandr Serguéievitch Púchkin. "E daí tudo é lavado, como que lambido por uma língua."

As particularidades de significados que a pequena Marina extrai dos poemas e atribui ao poeta de modo tão pessoal conferem ao texto um sentido mais amplo: o de uma experiência com Púchkin que é, ao mesmo tempo, coletiva e individual. No ensaio, Púchkin adquire os mais diversos significados: poeta, mestre, professor, negro, monumento, perseguido, assassinado, amaldiçoado, além de ser um deus, pois pode se tornar mortal ou divindade, fato ou símbolo, que permanecerá sempre o mesmo, até quando é outro. A atribuição de tantos significados, que sublinham a grandiosidade de Púchkin, é um exercício da autora para aproximar-se do poeta. Do "caldeirão de maravilhas da obra de Púchkin, ela pesca aquilo que outros não notam nem vêem motivos pra notar". 14

Em Meu Púchkin, revelam-se a universalidade e a natureza divina do poeta.

E digo mais: a ignorância dos meus tempos de criança que confundia elemento livre com versos era uma intuição: os "elementos

\footnotetext{
${ }^{14}$ МАСЛОВА, М. И. Мотив родства в творчестве Марины Цветаевой,152c. (MASLOVA, М. I. Motivos da infância na obra de Marina Tsvetáieva, p. 152).
} 
livres" eram os versos, mas não o mar, os versos, ou seja, o único elemento ao qual jamais se diz adeus.

Ao rememorar o Púchkin de sua infância, Marina Tsvetáieva pretende demonstrar que seu destino já havia sido escrito, antes mesmo de ela nascer. Cada poema de Púchkin representa aprendizado e revelação.

(...) aquilo que a gente sabe desde a infância, a gente sabe durante a vida inteira, mas aquilo que a gente não sabe na infância, não sabe a vida inteira.

Assim, nas confusões e mal-entendidos, a criança intuía espontaneamente a liberdade de ser poeta. 
Todo poeta se sente um exilado, na Rússia não é diferente. Um exilado do paraíso celeste e do paraíso terreno da natureza. No poeta - em todos os artistas - mas, sobretudo, no poeta, há a marca do descontentamento, que os faz serem reconhecidos - até em sua própria casa. Exílio vindo da Morte do tempo, do seu céu sem volta.

(Marina Tsvetáieva, O poeta e o tempo, 1932) ${ }^{15}$

Os primeiros versos de Marina Tsvetáieva foram escritos em francês, tal qual o mestre Púchkin. Era o ano de 1903 e a escritora vivia com sua irmã mais nova, num pensionato em Lausanne. No ano seguinte, as meninas mudaram-se para um outro pensionato, na Alemanha, e Tsvetáieva também escreveu versos em alemão. Depois dos acontecimentos de janeiro de 1905 na Rússia ${ }^{16}$ e da morte de sua mãe em Tarussa, a família retornou para Moscou. A poeta reencontrou a querida casa da rua Triokhprud, onde passara a infância ao lado da mãe, Mária Tsvetáieva (a principal influência, de quem herdou o amor à poesia), do pai, Ivan Tsvetáiev (presença não menos forte, que lhe ensinou o amor ao trabalho), dos meio-irmãos Valiéria e Andrei, e da irmã mais nova, Anastassia.

Em 1910, Marina Tsvetáieva publicou sua primeira coletânea, Álbum da tarde (Вечерний альбом). Seus poemas foram bem recebidos pela crítica, e a poeta começou a freqüentar os meios literários moscovitas de maior destaque.

\footnotetext{
${ }^{15}$ Поэт и время. "СС”, р. 329.

${ }^{16}$ Curiosamente, Púchkin retorna do exílio logo após a Revolta Dezembrista de 1825, que a exemplo do Domingo Sangrento de 1905 também durara só um dia.
} 
Por meio do amigo, poeta e crítico de arte Maksimilian Volóchin, conheceu Serguei Efron, com quem se casaria em janeiro de 1912, mesmo ano em que nasceria a primeira filha do casal, Ariadna.

Após ter passado por uma fase juvenil de puro "romantismo", na qual declara estar apaixonada pelo defunto Napoleão II, duque de Reichstadt, a ponto de querer morrer por ele, Marina Tzvetáieva adota uma atitude que conservará até o fim de sua vida: procurar a mesma plenitude em sua obra literária e em suas relações pessoais. Essa escolha irá separá-la dos outros membros do meio (...). ${ }^{17}$

Neste período, além de Álbum da tarde, a poeta publicou outro livro: Lanterna mágica (Волщебныцй фонарь, 1912). Nos dois primeiros livros, Tsvetáieva recria a atmosfera do cotidiano doméstico da infância em Moscou, os passeios ao bulevar Tvier, as aulas de música, a relação com a mãe e as irmãs - ou seja, o mesmo material autobiográfico que abordaria em Meu Púchkin e nos escritos em prosa dos anos de 1930.

A partir de 1913 a sua produção poética aumentou consideravelmente. A vida artística de Moscou estava no auge, os futuristas publicavam manifestos e antologias poéticas, e Marina Tzvetáieva pôde dedicar-se inteiramente à família e à obra. Em dezembro de 1913, ela escreveu em seu diário: "Nunca estive tão bonita, feliz e segura de mim como nesse inverno" ${ }^{\prime 18}$. Os poemas dessa fase,

\footnotetext{
${ }^{17}$ TODOROV, Tzvetan. "Prefácio". In: Vivendo sob o fogo, p. 19.

${ }^{18}$ Op. cit., p. 109.
} 
publicados após a morte da autora sob o título de Poesias Juvenis, marcam a fase de amadurecimento de sua poesia ${ }^{19}$.

Os acontecimentos em torno da Primeira Guerra Mundial não a abalaram particularmente. Tsvetáieva freqüentava os meios artísticos e envolvia-se em aventuras amorosas ("idílios cerebrais", nas suas palavras), que raramente resultavam em relações físicas. Essas paixões fugazes, das quais homens e mulheres eram alvos, inspiraram-lhe ciclos e ciclos de poemas ${ }^{20}$.

Quando das revoluções de fevereiro e outubro, Tsvetáieva vivia de modo tranqüilo, dentro do esquema ideal que havia criado para sua vida: dedicação ao trabalho poético e à família, que aumentara em abril de 1917 com o nascimento de Irina. Não tinha preocupações financeiras, pois vinha de família abastada, e a morte do pai, em 1913, rendera-lhe uma boa herança. Segundo Todorov, a exemplo do que ocorre a muitos poetas contemporâneos, Tsvetáieva não se opunha à idéia de Revolução, pois, para ela, essa traria em seu bojo também a possibilidade de uma revolução poética. Contudo, a revolução bolchevique não só não trouxe a esperada renovação artística como também destruiu a tranqüilidade de sua vida:

O que ela traz para a vida de Tsvetáieva, como para a de milhões de habitantes da Rússia, não é a realização de chavões bombásticos (o triunfo do povo, o poder dos sovietes), mas, antes de tudo, o desfazimento, a destruição. Questiona-se a propriedade privada, tomam-se os bens, rompem-se os elos entre uma geração e outra. Do dia

\footnotetext{
${ }^{19}$ Cf. Aurora Bernardini em Indícios flutuantes em Marina Tsvetáieva, op. cit. p, 27.

${ }^{20}$ Reunidos em coletânea publicada em 1922 sob o título de Verstas I (Bepcmbl I).
} 
para a noite, Tsvetáieva como tantos e tantos, encontra-se sem recursos. $^{21}$

Além disso, no início da Guerra Civil, seu marido alistou-se no Exército Branco, e o casal perdeu totalmente o contato. A escritora já não dispunha de recursos para sustentar-se, quanto mais para alimentar as filhas. Diante de tal situação, Tsvetáieva decidiu, em 1919, entregar as meninas aos cuidados de um orfanato, situado nos arredores de Moscou. Passados alguns meses, Ariadna, a mais velha, contraiu malária. A mãe foi buscá-la e dedicou-se integralmente à sua cura, por isso, quase não escreveu poemas nesse período. Em 7 de fevereiro de 1920, ao encontrar por acaso um funcionário do abrigo para órfãos, a escritora recebeu a notícia de que sua filha mais nova tinha morrido há quatro dias. A dor e a culpa pela morte de Irina acompanhariam a poeta até o fim de seus dias. Passados mais de dez anos, no dia 31 de março de 1931, Marina escreveu em seu diário:

Irina! Como será que morreu? O que será que sentiu? Será que ela se balançava? O que via em sua memória? Talvez, um fragmento da casa de Boris e Gleb ${ }^{22}$ - Ália - a mim? Será que ela cantava: “Ai - dudu - dudu - dudu...”? Será que ela compreendia alguma coisa? Qual foi a última coisa que ela disse? E do que ela morreu ${ }^{23}$

\footnotetext{
${ }^{21}$ Vivendo sob o fogo, p. 20.

${ }^{22}$ Ruas de Moscou nas quais Marina Tsvetáieva morou com Serguei Efron e as filhas.

${ }^{23}$ Vivendo sob o fogo, p. 183.
} 
Sobre os difíceis anos da Revolução, Tsvetáieva tinha escrito uma série de diários que pretendia publicar com o título de Índices terrestres (Зимние приметы $)^{24}$, mas devido ao seu teor político (a poeta não segue a linha de nenhum partido) o livro foi sistematicamente recusado. A respeito dessa obra, Tsvetáieva escreveu em carta de maio de 1923 ao escritor Roman Gul, um de seus melhores amigos durante a emigração:

É um livro de vida e de verdade, por isso ele é politicamente (ou seja, sob o prisma da mentira), claramente destinado ao fracasso. Nele há comunistas encantadores e membros do Exército Branco impecáveis; os primeiros verão apenas os últimos, e os últimos apenas os primeiros. ${ }^{25}$

Apesar das dificuldades materiais enfrentadas durante a Guerra Civil (1918-1922), sua produção poética foi intensa. Na Rússia, saíram os dois volumes de Verstas (1921 e 1922, respectivamente). Em 1922, Tsvetáieva, acompanhada da filha, deixou Moscou com destino a Berlim ${ }^{26}$, onde publicou duas coletâneas, Poemas a Blok e Separação. Alguns meses depois, partiu para a Tchecoslováquia, onde o marido já desfrutava de uma bolsa de estudos que o governo local destinava a emigrados russos. Em 1923, saíram mais dois livros em Berlim: Psiquê e Ofício. Uma vez estabelecida com a família na periferia de Praga, bolsista como o marido, compôs os poemas reunidos sob o título Depois

\footnotetext{
${ }^{24}$ Trechos deste diário foram publicados postumamente em "CC", p. 555.

${ }^{25}$ Vivendo sob o fogo, p. 245.

${ }^{26}$ Chegou à cidade alemã em 15 de maio de 1922.
} 
da Rússia (1922-1925) ${ }^{27}$, que seria publicado em 1928 na França, quando a poeta já morava no país.

De acordo com a observação de Aurora Bernardini em sua tese de livredocência Indícios flutuantes em Marina Tsvetáieva, a poeta consegue em seus poemas de Verstas I e II tudo aquilo que, para citar Boris Pasternak, "desejavam ser e não foram os outros simbolistas reunidos"; assim como em Depois da Rússia, no que diz respeito à síntese de sentido, palavra e música verbal, a poeta conseguiu resultados raramente alcançados pelos futuristas ${ }^{28}$. Já Elisabeth Burgos, em sua introdução à Carta a la amazona y otros escritos franceses, assim situa a poesia de Tsvetáieva:

Su lenguaje osado, el jugar a la vez con el ruso moderno, el ruso clásico y el lengaje popular, como lo hizo su admirado Pushkin en su época, la sitúan, aún hoy, más allá de la vanguardía. ${ }^{29}$

Marina Tsvetáieva não participou de nenhuma escola literária, nem tampouco filiou-se a um grupo político. Para ela, o único compromisso do poeta deveria ser com a própria obra, nunca com grupos literários; com a sua época, jamais com partidos políticos.

\footnotetext{
${ }^{27}$ Respectivamente: Версты I, Версты II, Психея, Ремесло е После России (1922-1925).

${ }^{28}$ BERNARDINI, Autora. Indicios flutuantes em Marina Tsvetáieva, p. 31-2.

${ }^{29}$ BURGOS, Elisabeth. "Introducción”. In: Carta a las Amazonas y otros escritos franceses, p. 19.
} 
O poeta não pode servir [a]o poder - porque ele mesmo é poder.

O poeta não pode servir [a]a força - porque ele mesmo é força.

O poeta não pode servir [a]o povo - porque ele mesmo é povo.

- e, por isso mesmo, poder - de uma ordem superior, força - de uma ordem superior etc.

O poeta não pode servir, porque ele já serve, ele serve integralmente. $^{30}$

Marina Tsvetáieva dizia-se “estenógrafa do ser” e, por isso, a única lei a que submetia a sua obra era a de sua verdade pessoal. Segundo ela, o poema representa tanto o grito através do qual se expressa toda uma época, quanto uma exigência da própria vida, pois "não se trata de modo algum de viver e escrever, mas de viver-escrever, e escrever - é viver." 31

Em 1925, ano em que nasceu seu terceiro filho, Gueórgui, Marina Tsvetáieva e a família mudaram-se para a França, onde viveram cerca de quatorze anos. Neste país, a vida também não seria nada fácil. Enquanto a escritora buscava de todas as maneiras sustentar a família - organizando saraus literários e publicando poemas e ensaios na imprensa russa da emigração ${ }^{32}-$, seu marido, que já não dispunha de rendimentos, revelava-se um eterno diletante, muito mais preocupado com a leitura de jornais do que com o sustento

\footnotetext{
${ }^{30}$ Op. cit., p. 422-423. Os colchetes corrigem problemas de revisão da edição.

${ }^{31}$ TODOROV, Tzvetan. "Prefácio". In: Vivendo sob o fogo, p. 421.

${ }^{32}$ A princípio, Tsvetáieva foi bem acolhida pelos russos emigrados, sua chegada é anunciada pela imprensa e ela não apenas publica seus textos, como também é assunto dos principais meios dos intelectuais russos exilados na França, contudo, suas posições políticas dificultam essa relação e a poeta vai aos poucos isolando-se da vida social.
} 
da família. Essa terrível situação material acompanharia a família até 1934, quando o ex-Branco Efron, tendo ingressado no serviço secreto da polícia soviética no início da década, começou a receber honorários pelos serviços prestados. À época, Marina Tsvetáieva mergulhara em seus trabalhos sobre Púchkin.

Em carta de 26 de junho de 1936, a poeta escreveu à Teskova:

Agora comecei a dedicar-me firmemente ao Púchkin, já fiz algo considerável, mas o meu sonho é traduzir todos os meus poemas favoritos (um por um). Isso é mais certo do que a salvação de uma alma que não quer ser salva. ${ }^{33}$

A presença de Púchkin, o grande mestre, é constante na obra da escritora, e, ao lado de Byron, aparece tanto como sugestão, quanto, referência ${ }^{34}$. Além de Meu Púchkin, Tsvetáieva dedicou ao poeta outro texto em prosa, também de 1937: Púchkin e Pugatchov (Пушкин и Пугачев). No primeiro, ela aborda a poesia de Púchkin, e no segundo, a prosa (sobretudo A filha do capitão e História de Pugatchov) ${ }^{35}$.

De fato, em toda a sua obra poética há versos dedicados a Púchkin. No período em que Tsvetáieva viveu na Rússia, escreveu três poemas: Encontro com Púchkin (Встреча с Пушкина), em 1913, Felicidade ou tristeza... (Счастие или грусть...), em 1916, е Рsiquê (Психея), em 1920. Já no período

\footnotetext{
33 "CC", p. 427.

${ }^{34}$ BERNARDINI, Aurora. Indícios flutuantes em Marina Tsvetáieva. p. 28.

${ }^{35}$ История Пугачева
} 
francês, compôs Poemas a Púchkin (Стихи к Пушкину), um ciclo de seis poemas, dentre os quais, dois receberam o subtítulo de $O$ poeta e o Tsar (Поэта и Царь). Sobre eles, Tsvetáieva escreveu em carta a Teskova:

Terrivelmente-bruscos, terrivelmente-livres, nada a ver com o Púchkin canonizado, mas tudo a ver com o oposto do cânone. Poemas perigosos. (...). Eles são tão revolucionários como nunca se sonhou na Rússia. (...) E não só esses poemas, mas também os de revolta e os que estão além da vida de Púchkin, os de revolta interior, com um desafio em cada linha.

O ciclo e as duas obras em prosa, escritos em 1931 e revisados em 1937, faziam parte de um projeto de Tsvetáieva, relativo às comemorações em memória dos 100 anos da morte de Púchkin. Para a data, a poeta pretendia colocar em prática um sonho: traduzir para o francês os poemas de Púchkin de que mais gostava. E dá conta disso aos amigos ${ }^{36}$.

Não por acaso, a autora cita em Meu Púchkin muitos dos poemas que escolheu para traduzir, como "À ama", "Os diabos", "Ao mar" (o seu preferido). Pode-se dizer que essas obras fazem parte de um único material de pesquisas no campo da criação literária. Assim, em Meu Púchkin, Tsvetáieva conta as primeiras impressões que a obra de Púchkin lhe causou na mais tenra idade, e, ao mesmo tempo, cita os poemas que tinha lido antes dos sete anos, a

\footnotetext{
${ }^{36}$ Em carta de 28 de junho de 1936, escreve à amiga Ariadna Berg: Envio a você mais uma tradução: 'Para as margens de tua pátria distante', eu tenho o grande sonho de traduzir todas as minhas poesias preferidas escritas por Púchkin - todas as minhas mais preferidas. (“CC”, p. $503)$.
} 
partir de de dois pontos de vista: o da criança, que se descobre poeta e se reconhece na poesia de Púchkin, e o da poeta adulta, que, ao traduzir o seu primeiro poeta russo para a língua francesa, afirma, mais uma vez, a sua descendência direta de Púchkin. 
Prosa e exílio

"Os anos levam-nos à prosa."

(Evguiéni Oniéguin, 1830)

Assim como Aleksandr Púchkin, Marina Tsvetáieva escreveu parte significativa de sua obra em prosa no último período de sua vida. Assim como Púchkin, Tsvetáieva era antes de tudo poeta. Ainda que os motivos que levaram um e outro a escrever em prosa sejam diversos, há nessa eleição um ponto em comum: a mudança foi determinada pela realidade prática que os poetas viveram, cada um a seu tempo.

(...) tudo leva a crer que não apenas os anos levaram Púchkin à prosa, não apenas a sua maior experiência na vida e na arte, mas ainda a sua insatisfação frente à prosa russa de seu tempo, o desejo de reformá-la e (o que não é de somenos importância) a consciência de que a prosa, em comparação com a poesia, poderia ser amplamente divulgada entre as mais diversas camadas da população. ${ }^{37}$

Para Marina Tsvetáieva, contudo, mais do que uma eleição no campo das buscas criativas, o empenho em praticar prosa como forma de escrita reflete uma imposição da própria vida. A vida no exílio trouxe mudanças significativas para a obra da escritora, decorrentes em grande parte das dificuldades materiais de sua família e da difícil relação com os editores. Nota-se que em sua obra os

\footnotetext{
${ }^{37}$ PAVLOVSKI, Piotr. O limite entre a prosa e a poesia em Púchkin, p. 132.
} 
poemas curtos vão aos poucos cedendo lugar para os poemas longos, os quais, por sua vez, diminuem em quantidade, à medida em que a década de 1930 se aproxima. De modo que, nesse período, sua produção é composta principalmente de textos em prosa. Se em sua terra ela não se entendera com os bolcheviques, na França, sua relação com os russos emigrados também não foi das melhores. A sua obra "recusada na Rússia devido a seus conteúdos políticos, poderia escandalizar os leitores da emigração por suas audácias formais" ${ }^{38}$. A partir de então Tsvetáieva mostrou-se menos audaz, contudo, o tratamento que deu aos temas abordados continuou tão complexo e rico de significados como em sua obra poética.

Em meados da década de 1930 ela escreveu a um correspondente não identificado:

(...) a prosa de um poeta é uma prosa excepcional, os versos de um prosador - versos execráveis, pois se os pudesse escrever, ele os teria escrito desse único jeito. (Exceção: sempre Goethe, que, de maneira geral - é sempre uma exceção.) A prosa de Púchkin é uma prosa de poeta. Os versos de Gógol são versos de um prosador. O poeta que aborda a prosa tem a escola do absoluto que é o verso, que o prosador que aborda a poesia não tem.

A opção pelo negro Púchkin em detrimento de Vermelhos e Brancos, a liberdade de escolher não escolhendo, a tentativa de preservar sua própria individualidade em um mundo dominado pela guerra entre grupos

\footnotetext{
${ }^{38}$ TODOROV, Tzvetan. "Prefácio”. In: Vivendo sob o fogo, p. 41.
} 
ferrenhamente rivais, dificultaram em grande parte a aceitação das obras de Tsvetáieva. Para os exilados, era fundamental que se escolhesse o lado dos brancos. Para Marina Tsvetáieva, que não se escolhesse lado algum. Contudo, as tentativas de publicar no meio francês quase sempre fracassavam, pois, como assinala Tzvetan Todorov, a poeta tinha que enfrentar o sentimento de autosuficiência da sociedade literária de Paris, e a condescendência típica para com as escritoras e o caráter sovietófilo da intelligentsia francesa. Some-se ainda a isso o fato de sua estética literária ser bastante diversa do que se produzia na França neste período. Sua única saída era tentar publicar em russo na imprensa da emigração, a qual, no entanto, não a via com bons olhos. Sintomaticamente, o grosso de suas publicações nessa imprensa (especialmente na década de 1930) é constituído por trabalhos sobre Púchkin, o mesmo Púchkin que iria abrir-lhe as portas da imprensa francesa, com a publicação, na revista La vie intellectuelle $e^{39}$, de cinco poemas, que Tsvetáieva traduziu para o francês.

Em carta de 1936 à Anna Teskova ${ }^{40}$, uma de suas principais confidentes durante essa década, a poeta assim resumiu:

Quase não escrevo poesias, e eis o porquê: eu não posso limitarme a um único poema, eles são para mim como uma família, são ciclos, semelhantes a funis e até a redemoinhos, nos quais eu entro e, portanto, é também uma questão de tempo. (...) E meus poemas, esquecendo-se de que sou poeta, não são aceitos em lugar algum, ninguém pega sequer um

\footnotetext{
${ }^{39}$ Fundada em 1828 pelos padres dominicanos, foi uma das revistas mais importantes da França dos anos 1930.

${ }^{40}$ Anna Antonovna Teskova (1872-1954), escritora e tradutora tcheca.
} 
verso. "Lugar algum" e "ninguém" chamam-se "Posliédni Nóvosti" e

"Sovremiénie Zapíski" "41, outros lugares não há. (...)

A emigração fez de mim uma prosadora. Claro, é prosa minha, e é a melhor do mundo depois dos poemas, é uma prosa lírica, mas não passa de prosa. ${ }^{42}$

Tsvetáieva considerava a prosa como um gênero menor. Talvez por isso mesmo, do ponto de vista formal, ela reproduza em seus ensaios, artigos e até mesmo nas cartas, os princípios que regiam as leis de sua poesia. Parafraseando o que diz Piotr Paliévski sobre a inexistência de fronteiras entre prosa e poesia na obra de Púchkin, pode-se dizer de Marina Tsvetáieva que

O verdadeiro limite está entre o poético e o prosaico, compreendidos como princípios os mais amplos, em oposição um ao outro. Por poético subentende-se a vida, cônscia do seu ideal e capaz de alcançá-lo. Por prosaico entende-se a lucidez do mundo da necessidade e a "força das coisas". Ambos os princípios, como é natural, interpenetram-se e penetram todos os gêneros, tanto da prosa como da poesia. $^{43}$

Assim como o mestre, também a poeta coloca-se, no âmbito da tarefa vital e íntima do ser, incondicionalmente ao lado da poesia.

\footnotetext{
${ }^{41}$ Revistas editadas pela emigração branca em Paris.

${ }^{42}$ ЦВЕТАЕВА, М. И. Собрание сочинений: $В 7 \mathrm{~m}$. Том 6, 448c.

${ }^{43}$ PAVLOVSKI, Piotr. O limite entre a prosa e a poesia em Púchkin, p. 136-7.
} 
A exemplo do que se observa na prosa de Aleksandr Púchkin, também no caso de Marina Tsvetáieva é inútil tentar enquadrar suas obras em prosa num único gênero literário, uma vez que cada texto possui uma forma própria. Em alguns ensaios, como Mamãe e a música, O Diabo, Os flagelados, Meu Púchkin, Púchkin e Pugatchov em que a escritora volta os olhos para o seu mundo infantil, e Conto de Sônietchka e Natália Gontcharova, ambos sobre personalidades de destaque no meio artístico russo, o elemento mais forte é o autobiográfico. Já em ensaios como $A$ arte à luz da consciência e $O$ poeta e o tempo $^{44}$ sobressaem-se elementos de crítica literária. Contudo, em todos os seus textos, nota-se a existência desses dois elementos, arranjados de modo indissociável.

A prosa de Marina Tsvetáieva é a representação literária de sua própria vida. Em sua vasta produção - entre memórias sobre os contemporâneos, ensaios autobiográficos, artigos sobre literatura, diários e cartas, e mesmo em seus escritos franceses ${ }^{45}$ - percebe-se a pesquisa incessante sobre sons e significados de palavras da língua eleita, o que se revela nos inúmeros trocadilhos e jogos de palavras encontrados em qualquer texto seu. Tzvetan Todorov, em Vivendo sob o fogo, comenta que até mesmo em carta a Béria, na qual pedia a libertação de seu marido e sua filha, a poeta foi incapaz de abrir mão dos recursos que tornaram inconfundível a sua escrita. Nos ensaios de

\footnotetext{
${ }^{44}$ Respectivamente: Мать и Музыка (1935), Черт (1935), Хлыстовки (1934), Повесть о Сонечке (1937), Наталивя Гончарова (1929), Искусство при свете совести (1932) е Поэт и время (1932).

${ }^{45}$ São eles: Mon frère féminin: Lettre à l'Amazon (1932) - uma possível resposta ao livro da escritora Nathalie Barney, The Amazon - e Neuf lettres avec une dixieme retenue et une onzieme recue (1922), novela formada por uma sequiência de doze cartas e um posfácio. Sobre a relação de Tsvetáieva com a língua francesa, diz Hélène Cixous: "La cuestión del idioma es absolutamente esencial. Tsvietáieva tenia un dominio perfecto de las lenguas extranjeras. Habría entonces que emprender todo un trabajo de análisis sobre lo que significa una lengua extranjera: el francés es una lengua extranjera e no extranjera para Tsvetáieva; se sentía en ella como pez en el agua; como lo hacía en ruso o en alemán: lengua entonces otra e no otra, extranjera e no extranjera."
} 
Marina Tsvetáieva, as fronteiras entre os gêneros da poesia e da prosa são constantemente rompidas, de modo que a prosa torna-se poesia e vice-versa. Lêem-se versos disfarçados de frases e estrofes travestidas de parágrafos, enfim, poesia com aparência de prosa, tal como fazia Andrei Biéli ${ }^{46}$.

Marina Tsvetáieva identificou-se com Púchkin, e jamais deixou de fazer referência a ele. Assim, ao dedicar-lhe uma série de obras em verso e prosa, nos anos de 1930 (ou seja, o último período de sua vida), Tsvetáieva pretendia não somente atestar sua filiação, mas também reforçar o caráter de exceção que o poeta tem - o que fica claro pela maneira como ela o trata em Meu Púchkin. No ensaio, Marina Tsvetáieva atribui a cada ato vivido uma dimensão poética que passa não apenas pelo advento da palavra, mas também pelas imagens que a antecedem, e remetem a um tempo em que as pinturas em sua casa prenunciavam seu destino. Na casa da Triokhprud havia três quadros que preparavam “a criança para o século do terror que a esperava”. Entre eles, estava a obra de Naúmov, $O$ duelo de Púchkin com D'Anthès, que representava a morte de Púchkin, e ensinou à criança que todo poeta, vivo ou morto, é negro, uma exceção; e que todo poeta, morto foi assassinado, e todo poeta vivo será morto.

Além disso, ao assinar Aleksandr Serguéievitch Púchkin no momento em que termina de escrever o poema Ao mar no rochedo, Marina Tsvetáieva fundese com Púchkin no campo da poesia, e, nesse sentido, o conteúdo também extrapola os limites da obra.

\footnotetext{
${ }^{46}$ Cf. O romance São Petersburgo. Marina Tsvetáieva dedica um texto em prosa a Andrei Bieli intitulado Um espírito prisioneiro.
} 
Quando escreveu o poema Ao mar, em 1824, Púchkin deixava Odessa, cidade ucraniana,onde estivera exilado, para retornar à Rússia. Mas não como homem livre. O poeta havia sido condenado à reclusão na propriedade da família em Mikháilovskoe. Nesse ano, Púchkin tramou fugir para o estrangeiro através do mar Negro. O mesmo mar Negro de que Púchkin despedia-se, e que era imaginado pela menina Tsvetáieva aos pés do monumento a Púchkin, no bulevar Tvier. Em Ao mar, Púchkin dava adeus à possibilidade de libertar-se da perseguição tsarista e dirigia-se para uma prisão, ainda que domiciliar. Dois anos depois, com a morte de Alexandre I e a ascensão de Nicolau I ${ }^{47}$, Púchkin finalmente conseguiu permissão para voltar a viver em Petersburgo, cujo preço foi ter suas obras censuradas pelo próprio tsar. Em vez de ter o mar de elementos livres abaixo de si, o monumento a Púchkin $^{48}$ era circundado de pedras e correntes. Desse modo, a "idéia maravilhosa" de "dar a Moscou, aos pés do poeta, um mar" é substituída pela "idéia sombria" de "colocar um gigante cercado de correntes", circundado pelos braços do tsar Nicolau I, "que nunca abraçaram o poeta e que sempre o cercearam".

Em carta de 1937 a Teskova, Tsvetáieva refletia sobre o destino de seu primeiro poeta:

(...) se Nicolau I não mantivesse Púchkin no cabresto - bem perto de si - se ele o soltasse para o exterior, se o libertasse para

\footnotetext{
${ }^{47}$ No que diz respeito às sucessões do trono russo, é interessante notar que Marina Tsvetáieva nasce em 1892, sob o domínio de Alexandre III, que morre em 1894, ano em que ascende ao trono Nicolau II, o último tsar da Rússia.

${ }^{48} \mathrm{O}$ monumento a Púchkin está para Moscou assim como a estátua eqüestre de Pedro, o Grande, personagem do Cavaleiro de Bronze, de Púchkin, está para São Petersburgo.
} 
percorrer os quatro cantos, D'Anthès não o teria assassinado. O tsar foi o primeiro a matá-1o em seu interior. ${ }^{49}$

Assim também Tsvetáieva, sem leitores que lhe fizessem eco, privada do convívio familiar (a filha e o marido retornariam à URSS justamente no ano de 1937), e com uma produção literária cada vez mais escassa, parecia dar sinais de que havia morrido (ou estava morrendo) por dentro. Como aponta Elizabeth Burgo, se em sua obra Tsvetáieva muitas vezes se antecipa aos fatos de sua vida, ela também se antecipa à sua morte.

Su estructura es tan fuerte, que inconscientemente se adelanta a su destino. Su obra abarca la totalidad de su vida, precediendo al acontecimiento. (...) A tal punto, que su obra parece póstuma. Ella que se declaró hermana de Pushkin, en la premonición de la muerte: ambos fueron afines. Pushkin, en Eugenio Oniéguin, relata la trama que conduce a un duelo y a la muerte. Escenario casi idéntico al del duelo en el que más tarde Pushkin perdiera la vida. ${ }^{50}$

Quando Marina Tsvetáieva escreveu Meu Púchkin, em 1937, parecia já saber que a volta à URSS, bem como o seu fim trágico, seriam inevitáveis. Ao reconstruir com palavras a despedida do mar (de Púchkin e da pequena Marina), Tsvetáieva parece dar adeus não à França ou ao exílio, mas sim, à própria vida.

\footnotetext{
49 "CC", p. 488.

${ }^{50}$ Carta a la Amazona y otros escritos, p. 19.
} 


\begin{abstract}
"Quando Mur estiver crescido (como Ália) ${ }^{51}$ - não poderei nem sequer pensar naquela função [de ser mãe]. Em dez anos estarei absolutamente só, na soleira da velhice. E terei tido - do começo ao fim - uma vida de cão.”
\end{abstract}

(Marina Tsvetáieva, em carta de 1931)

Como muitos de seus contemporâneos, Marina Tsvetáieva teve a vida determinada pelos terríveis acontecimentos que marcaram a sua época. O período em que viveu compreende a Revolução Russa, as duas guerras mundiais, a ascensão dos regimes totalitários na Europa e de Stálin na Rússia. Considerada uma das maiores escritoras do início do século passado, Tsvetáieva teve também um destino trágico.

Durante o perído em que se dedicou aos trabalhos sobre Púchkin, a escritora já se encontrava exilada na França há mais de uma década, Entretanto, o retorno de sua família para a União Soviética já se prenunciava, apesar de, em 1935, num encontro em Paris, seu grande amigo, correspondente e eventual amante Boris Pasternak ter lhe desaconselhado a fazê-lo. Em março de 1937, a filha de Tsvetáieva, Ariadna, embarcou num trem de volta para Moscou; em outubro do mesmo ano, seu marido, Serguei Efron, envolvido no assassínio de Ignace Reiss ${ }^{52}$, deixou a França com destino a Leningrado, atual São

\footnotetext{
${ }^{51}$ Gueórgui e Ariadna Efron, respectivamente.

52 Agente do Komintern (Internacional Comunista, 1919-1943) a serviço da URSS na França, que havia rompido com o regime stalinista em 1937. Serguei Efron, combatente do exército branco na Revolução, quando chega à França, levado por circunstância até hoje não muito
} 
Petersburgo. Dois anos mais tarde, seria a vez de Tsvetáieva e seu filho mais novo Gueórgui retornarem.

Pouco antes de voltar à URSS, em 1938, quando da anexação da Áustria à Alemanha, Tsvetáieva escreveu um ciclo de poemas intitulado Poemas à Tchecoslováquia, o qual parece ter sido muito bem recebido pela cúpula do governo soviético. São 16 poemas caracterizados por uma violenta invectiva contra o Nazismo. No ensaio Meu Púchkin, escrito cerca de dois anos antes, há uma bela passagem em que a autora, ao abordar o tema das teorias racistas, faz uma clara referência às teorias de Hitler sobre a hegemonia da raça ariana:

O monumento a Púchkin adiantando os acontecimentos é um monumento contra o racismo, em prol da igualdade racial, em prol da primazia de cada raça, desde que produza um gênio. (...) O monumento a Púchkin é uma prova viva de que a teoria racista não passa de infâmia e morte, é uma prova viva de que só o seu contrário é verdadeiro. Púchkin é o fato que derruba a teoria.

Seria um tanto exagerado afirmar, como faz Elizabeth Burgos em seu prefácio à Carta a la Amazona y otros escritos franceses, que Serguei Efron determinou o caminho da morte para Marina Tsvetáieva. Ao examinar a biografia da autora, é possível notar que em momentos cruciais suas atitudes foram orientadas, em certa medida, para "seguir" o marido. Quando o combatente do exército branco se viu obrigado a deixar a Rússia depois da 
Revolução de Outubro, a esposa o encontraria em Praga. Da mesma maneira, vinte anos mais tarde, quando tiveram início os Processos de Moscou, e o agente da $\mathrm{NKVD}^{53}$, caído em desgraça, teve que retornar à URSS, Tsvetáieva decidiu deixar Paris, ainda que em nome dos filhos.

Contudo, como observa Tzvetan Todorov em Vivendo sob o fogo, Marina Tsvetáieva apoiara sua vida na tríade "família-obra-amor", de modo que as decisões tomadas por ela foram sempre no sentido de contemplar sua verdade individual.

Tsvetáieva não tem escolha. Mesmo assim, ela hesita: politicamente é bem mais lúcida que seu marido, um apaixonado, e sabe que não haverá vida para ela na União Soviétiva. Mas o que a França lhe reservaria, por acaso era vida? O fiel da balança, no fim, será a hierarquia dos valores aos quais ela decicidiu aderir, sendo o mais importante o devotamento à família. ${ }^{54}$

Chegando a Moscou, em 19 de junho de 1939, Marina Tsvetáieva assistiu às prisões da filha, em 27 de agosto, e do marido, em 10 de outubro, ambos acusados de pertencerem ao serviço secreto francês. ${ }^{55}$ Os processos de Serguei e Ariadna seguiram a rotina das condenações políticas da época. Após um mês sob tortura no presídio de Lubianka, a moça "confessou" e foi condenada a oito

\footnotetext{
${ }^{53}$ Policia secreta do Partido Comunista da União Soviética.

${ }^{54}$ TODOROV, Tzvetan. "Prefácio". In: Vivendo sob o fogo, p. 51.

${ }^{55}$ Tzvetan Todorov aponta duas razões possíveis para esta acusação: primeiro, a troca do chefe da NKVD resultou na eliminação daqueles que pertenceram ao grupo anterior; segundo, a confissão de Efron desempenharia papel central no processo de algum quadro ilustre do partido que viria a ser acusado de atos anti-stalinistas. (cf. Vivendo sob o fogo, p. 706-707).
} 
anos de trabalhos forçados no campo do Grande Norte, acusada de espionagem e atividade anti-soviética. Serguei Efron, por sua vez, jamais admitiu ter sido espião contra a União Soviética, e muito menos chefe de um grupo de espiões a serviço da França, mas foi devidamente condenado por crime de espionagem, dois anos após a sua prisão.

Entretanto, Marina Tsvetáieva tentava inutilmente provar a inocência dos familiares, escrevendo cartas a burocratas do regime. Ariadna e Serguei continuavam presos e a poeta buscava em vão obter permissão para visitá-los. Sua vida cotidiana resumia-se ao trabalho doméstico, e ela quase não escrevia mais poemas. A última tentativa (infrutífera) de publicação data de 1940, e diz respeito a uma coletânea de poemas dedicados a Efron, escritos em 1920 e revisados para uma possível edição soviética. As suas condições materiais eram péssimas, o pouco rendimento que conseguia com traduções de poemas ${ }^{56}$ mal dava para o sustento seu e do filho. Tsvetáieva estava deprimida, pois tinha sido privada justamente daquilo "que lhe dava a sensação de viver: amor, criação artística, família."57

\footnotetext{
Para Marina Tsvetáieva, cuya vida fue signada por el exilio, sólo la palabra escrita tenía el poder de anular la separación, de animar la ausencia, de saturar el deseo. (...) Existen muchos tipos de exilio: el más dolorosa tal vez sea el del retorno al país natal, el del destierro dentro de su propia tierra. Marina Tsvetáieva, con su clarividencia excepcional, y por haberlos vividos todos, no ignoraba la variedad de
}

\footnotetext{
${ }^{56} \mathrm{Na}$ verdade, Tsvetáieva reescreve em versos traduções literais feitas a partir das mais diversas línguas, particularmente, dos poemas do georgiano Vaia Pchavela (1861-1915).

${ }^{57}$ TODOROV, Tzvetan. "Prefácio". In: Vivendo sob o fogo, p. 59.
} 
los exilios. El poeta, por ser poeta es siempre un exilado: y por haber sido como poeta, revolucionaria, Marina fue víctima de la historia. ${ }^{58}$

Em 1941, na noite de 21 para o dia 22 de julho, a Alemanha invadiu a URSS, e deu início aos bombardeios contra Moscou. A cidade foi evacuada. Marina Tsvetáieva deixou a capital em 8 de agosto. Depois de 20 dias de viagem, chegou com o filho a Elábuga, cidade pertencente à República do Tartaristão. Nesse momento, a última decisão parecia já ter sido tomada. Se deveriam morrer, seria ela a primeira. Antes de suicidar-se, escreveu três cartas: na primeira, destinada a quem encontrasse o seu corpo, ela pedia que acompanhassem o seu filho Gueórgui até a casa de certo escritor, para quem, aliás, endereçara a segunda carta, e na terceira, que era para o filho, reafirmava o amor pela família, e se dizia "num beco sem saída". Em 31 de agosto, Marina Tsvetáieva enforcou-se. Fez-se o silêncio. ${ }^{59}$

\footnotetext{
${ }^{58}$ Carta a la Amazona y otros escritos, p. 14.

${ }^{59}$ Com a entrada da Rússia na Segunda Guerra Mundial e a invasão de Moscou, os presídios precisavam ser esvaziados e, por isso, seus internos foram executados. Serguei Efron estava entre eles; foi fuzilado em outubro de 1941, um mês e meio após a morte de Tsvetáieva. Gueorgui Efron alista-se no Exército Vermelho e morre no front em 1944. Assim que termina sua pena, em 1947, Ariadna Efron é libertada. Em 1949 é detida novamente e, pelos mesmos motivos, é condenada à prisão perpétua, cumprida na Sibéria. Com a morte de Stálin, é finalmente libertada e dedica o resto de sua vida a reunir e publicar as obras de sua mãe. Ariadna Efron morre em julho de 1975
} 


\section{Nota geral à tradução}

O ensaio Meu Púchkin foi publicado pela primeira vez no número 64 da revista Notas contemporâneas (Современые Записки), em 1937. Esta tradução baseou-se na versão publicada em Марина Цветаева - в завтра речь держу... - Автобиографическая проза (Marina Tzvetáieva - deixo as palavras para amanhã... - Prosa autobiográfica), uma coletânea de textos em prosa de Marina Tsvetáieva organizada por Anna Saakiants e Lev Mukhin, em 2005.

Com o intuito de proporcionar ao leitor um melhor entendimento da obra, serão comentadas nas notas de rodapé questões relativas à tradução, fatos da biografia de Tsvetáieva e de Púchkin, e os poemas deste que aparecem citados pela autora. Nesse sentido, cabe dizer que na tradução ora apresentada, procurou-se preservar, na medida do possível, as rimas e a métrica dos originais. Desse modo, os versos iâmbicos e trocaicos dos tetrâmicos puchkinianos na versão para o português foram recriados em versos octassílabos, decassílabos ou dodecassílabos.

A poesia e a prosa de Marina Tsvetáieva distingue-se por um uso particular do tirete. Além dos usos habituais da língua russa, na qual o sinal gráfico aparece como marca do verbo "ser/estar" (no presente do indicativo e nos casos de aposto e de orações explicativas) e no lugar dos parêntesis ou das vírgulas (a exemplo do que se passa em português), a escritora se vale desse meio tipográfico para dar maior destaque a palavras e frases do 
seu discurso. Nos escritos de Tsvetáieva, o tirete faz as vezes de um sinal de igualdade, de equivalência. Sendo assim, em nossa tradução reproduzimos todos os tiretes que aparecem no original, com exceção daqueles que substituem o verbo "ser/estar", pois tal recurso nem sempre é praticável na língua portuguesa. 


\title{
Meu Púchkin
}

\author{
Marina Tsvetáieva
}


Começa como um capítulo do romance de cabeceira de todas as nossas mamães e vovós - "Jane Eyre" - 0 segredo do quarto vermelho. ${ }^{60}$

No quarto vermelho havia um armário secreto ${ }^{61}$.

Mas, antes do armário secreto, havia outra coisa, havia um quadro no quarto de mamãe - "0 duelo"62.

Neve, galhos negros de arbustos, dois homens negros arrastam um terceiro pelas axilas para o trenó - e um ainda, outro, que se afasta de costas. 0 arrastado é Púchkin, o que se afasta - d'Anthès. D'Anthès desafiou Púchkin para um duelo, ou seja, atraiu-o para a neve e, lá, entre os arbustos negros e desfolhados, matou-o.

A primeira coisa que eu fiquei sabendo de Púchkin foi - que o tinham matado. Depois, fiquei sabendo que Púchkin era um poeta e d'Anthès - um francês. D’Anthès cismara de odiar Púchkin, porque ele próprio não era capaz de escrever versos, e desafiou-o para um duelo, ou seja, atraiu-o para a neve e, lá, com um tiro de pistola na barriga, matou-o. Eu tinha três anos quando fiquei sabendo que poeta tem barriga e - penso em todos os poetas com os quais algum dia me encontrei - com essa barriga de poeta, quase sempre vazia e pela qual Púchkin foi morto, preocupava-me não menos do que com sua alma. 0 duelo de Púchkin fez nascer em mim a irmã. Eu diria

\footnotetext{
60 Jane Eyre: romance da escritora inglesa Charlotte Brontë (1816-1855). 0 segredo do quarto vermelho é um episódio da infância da narradora-protagonista e aparece no início do romance. Neste episódio, a pequena Jane Eyre é trancada no quarto vermelho, local onde falecera seu tio e protetor. 0 tema central da narração é a história de amor da pobre governanta Jane Eyre e do rico e solitário Lorde Rochester.

${ }^{61}$ Não há no quarto vermelho do romance Jane Eyre alusão a um armário secreto. Tsvetáieva refere-se aqui ao armário que ficava no quarto de sua meia-irmã mais velha.

${ }^{62}$ Referência à tela $O$ duelo de Púchkin com D'Anthès, de A. A. Naúmov, pintada em 1884.
} 
mais - há para mim na palavra barriga algo de sagrado - até mesmo ante o simples "dor de barriga", invade-me uma onda trepidante de compaixão, excluindo qualquer senso de ridículo. Nós todos fomos feridos com este tiro na barriga.

Nenhuma menção a Gontcharóva, e eu apenas fiquei sabendo dela quando já era adulta. Uma vida inteira mais tarde, agradeço calorosamente esse silêncio de minha mãe. Uma tragédia pequeno-burguesa adquiriu a grandeza de um mito. É isso, no fundo, neste duelo um terceiro não havia. Havia dois: qualquer um e o único. Ou seja, os eternos personagens da lírica puchkiniana: o poeta - e a plebe ${ }^{63}$. A plebe, desta vez em uniforme de cavalheiro da guarda, matou - o poeta. E Gontcharova, assim como Nicolau I - sempre existirá.

- Não, não, não, isso tudo não passa de imaginação sua - dizia mamãe sem ter a menor idéia de quem era este sua - Ferido mortalmente, na neve, mas não se furtou ao tiro! Ele apontou, acertou e ainda por cima disse a si mesmo: bravo! - num tom de tamanho entusiasmo que para ela, uma cristã, o mais natural seria: "Mortalmente ferido, banhado em sangue, ele perdoou o inimigo!” Largou o revólver, estendeu a mão, - com isso, com todos nós, evidentemente devolve Púchkin para a África natal ${ }^{64}$, terra de vingança e paixão, e sem suspeitar que lição - senão de vingança - ao menos de paixão, dava a mim, de quatro anos, que mal sabia ler.

\footnotetext{
63 Alusão ao poema de Púchkin "O poeta e a turba" ("Поэта и толпа"), de 1928, em que o poeta é contraposto à plebe.

${ }^{64} \mathrm{O}$ bisavô de Púchkin, Ibrahim Hannibal, era de origem africana. Até a pouco tempo acreditava-se que Púchkin era de origem abissínia, mas pesquisas recentes revelam que o negro de Pedro, o Grande era natural do antigo Sudão Central, região sul do lago Tchad e ao norte de Camarões. (SCHNAIDERMAN, Boris. "Prefácio", p. 9. In: A dama de espadas).
} 
Preto e branco, sem traço de cor, o quarto de mamãe, janela preta e branca: a neve e os galhos daqueles arbustos, o quadro preto e branco - "0 duelo" - onde na brancura da neve aconteceu uma situação preta: a eterna situação preta da morte do poeta pela - plebe ${ }^{65}$.

Púchkin foi meu primeiro poeta e o meu primeiro poeta foi morto.

Desde esse momento, sim, desde o momento em que Púchkin diante dos meus olhos no quadro de Naúmov foi morto - mataram, a cada dia, a cada instante, continuaram a matar toda a minha infância, meninice, juventude - dividi o mundo entre o poeta - e o resto, e escolhi - o poeta, para proteger escolhi o poeta: defender - o poeta - do resto, pouco importando como se vistam ou se chamem.

Havia três quadros desses na nossa casa da Triokhprud ${ }^{66}$ : na sala de jantar - "Aparição de Cristo ao povo"67, com o mistério nunca resolvido de um Cristo bem pequeno e inexplicavelmente-próximo, bem próximo e inexplicavelmente-pequeno; o segundo, sobre a estante de partituras na sala - "Os tártaros" - tártaros em túnicas brancas, numa casa de pedra sem janelas, entre colunas brancas, matando o chefe tártaro ("Morte de César"68) e - no quarto de minha mãe - "O Duelo". Duas mortes e uma aparição. E todos os três eram terríveis, incompreensíveis, ameaçadores, e

\footnotetext{
${ }^{65}$ Estabelece-se aqui um jogo entre o adjetivo tchiórny e o substantivo tchiérn', as quais foram traduzidas por "preto" e "plebe", respectivamente. Além de as duas palavras possuírem o mesmo radical, tchiórny pode ser usado como sinônimo de tchiérn', não no sentido estrito de "plebe", mas para referir-se a pessoas da classe baixa de qualquer sociedade, a "ralé".

${ }^{66}$ Rua de Moscou onde se localizava a casa da família Tzvetáiev.

${ }^{67}$ Tela de Alexandr Andreiévitch Ivanov (1806-1858).

${ }^{68}$ Tela do pintor italiano Vincenzo Camuccini (1773-1844) sobre os assim chamados Idos de Março. Camuccini, de orientação neoclássica, ficou conhecido por privilegiar temas históricos e religiosos. Nota-se, ainda, que "Os tártaros" era o nome que a pequena Tsvetáieva atribuía ao quadro.
} 
o batismo com aquelas pessoas e crianças negras de cabelos crespos, nariz aquilino, todos nus e nunca dantes vistos, enchia de tal maneira o rio que não sobrava uma gota de água livre, era não menos terrível que os outros dois, e todos eles preparavam muito bem a criança para o século do terror que a esperava.

Púchkin era negro. Púchkin tinha suíças (NB! Somente negros e velhos generais as tinham), Púchkin tinha o cabelo para o alto e os lábios protuberantes, e olhos negros, com o branco dos olhos azul como os de um cachorrinho, - negros, a despeito dos evidentes olhos claros em numerosos retratos seus. (Se é negro - são negros ${ }^{69}$ ).

Púchkin era um negro igualzinho àquele negro da galeria Aleksándrovski, que a mamãe e eu íamos juntas olhar, lá, ao lado de um urso branco, em cima de uma fonte eternamente-seca: será que ela ia jorrar? Fontes nunca jorram (e como fariam isso?), o poeta-negro russo, o poeta-negro e o poeta estão mortos.

(Deus, dito e feito! Que poeta, vivo ou morto, não é negro, e que poeta - não foi morto?)

Mas mesmo antes de "O duelo" de Naúmov - pois cada lembrança tem sua pré-lembrança, como se fosse uma escada de bombeiros pela qual se desce de costas, sem saber se há mais um degrau - o que sempre há - ou um repentino céu noturno onde se descortinam todas as estrelas, das mais altas

\footnotetext{
${ }^{69}$ Púchkin tinha cabelos e olhos claros (N. do A.).
} 
às mais longínquas - mas, antes de "O duelo" de Naúmov havia outro Púchkin, Púchkin - de quando eu ainda não sabia que Púchkin era Púchkin. Púchkin, não lembrança, mas estado, Púchkin - de sempre para todo o sempre -, antes de "O duelo" de Naúmov havia o amanhecer e de onde surgia, de onde saía, cortando-o com os ombros como o nadador - o rio havia um homem negro mais alto do que todos e mais negro do que todos de cabeça inclinada e chapéu na mão.

0 monumento de Púchkin ${ }^{70}$ não era a estátua de Púchkin ${ }^{71}$, mas simplesmente o Monumento-de-Púchkin, numa única palavra, eram dois estranhos, monumento e Púchkin, que não existiam separadamente. Aquilo que é eterno, debaixo de chuva ou debaixo de neve, - oh, como eu vejo esses ombros cobertos de neve, toda a neve russa cobre e pesa nos ombros africanos! - com os ombros ao amanhecer ou sob a nevasca, quer eu venha ou vá, saia ou chegue, ele está ali com o eterno chapéu na mão e seu nome é "Monumento-de-Púchkin".

0 monumento de Púchkin era a meta e o limite do passeio: do monumento de Púchkin - ao monumento de Púchkin. 0 monumento de Púchkin era também a meta da corrida: quem chegasse antes ao Monumento-de-Púchkin. Somente a bá de Ácia ${ }^{72}$, às vezes, por simplicidade, abreviava: "Vamos sentar no Púchkin", - ao que eu sempre retrucava com

\footnotetext{
${ }^{70}$ Referência ao monumento a Púchkin, em Moscou.

${ }^{71}$ No original russo, aparece a seguinte locução entre parêntesis: "rodítielni padiej", que quer dizer "caso genitivo". Optou-se por omitir o termo, pois em português não temos o mesmo fenômeno gramatical.

${ }^{72}$ Hipocorístico de Anastassia.
} 
minha pedante correção: "Não é no Púchkin, mas no Monumento-dePúchkin".

O monumento de Púchkin foi também a minha primeira unidade de medida espacial: dos Portões de Nikitsk ao monumento de Púchkin dá uma versta, a mesma eterna versta de Púchkin, a versta de "Os diabos", a versta de "Estrada invernal", a versta de toda a vida de Púchkin e de nossas antologias infantis, listrada e saliente, enigmática e habitual ${ }^{73}$.

O monumento de Púchkin era parte - da rotina, uma personagem da vida infantil tanto quanto o piano de cauda e o guarda ${ }^{74}$ Ignátiev janela à fora - que, aliás, ali plantado era tal-qualmente inabalável, porém não tão alto - o monumento de Púchkin era um dos dois (o terceiro não havia) passeios cotidianos e inevitáveis - aos Lagos do Patriarca ${ }^{75}$ - ou ao Monumento-de-Púchkin. E eu preferia ir - ao Monumento-de-Púchkin porque eu adorava, tanto que na corrida podia abrir e até mesmo $\operatorname{rasgar}^{76}$ a minha "blusinha" branca, que me enforcava, presente do vovô de Carlsbad, correr até ele e, ao chegar lá, dar a volta nele e, daí, erguendo a cabeça, olhar para o gigante de rosto negro e mãos negras, que não olhava pra mim, e não se parecia com nada nem com ninguém na minha vida. E às vezes simplesmente ficar pulando em volta dele sobre uma perna só. E, apesar de

\footnotetext{
${ }^{73}$ Lá, tal versta inesperada

Ele irrompe a minha frente... ("Os diabos")

Púchkin aqui fala sobre um marco que indica verstas.

Nem fogo, nem casa preta

Ermos e neves... Ao meu encontro

Apenas verstas listradas... ("Caminho de inverno")

(N. do A.)

${ }_{74}$ Gorodovói, no original: policial urbano da Rússia tzarista.

${ }^{75}$ Optou-se por fugir da norma de não traduzir nomes próprios ou topográficos, porque neste caso o significado do nome é utilizado como elemento de composição.

76 Em russo, paranomásia entre os verbos "abrir" (raskrivat') e "rasgar" (rasrivat').
} 
o Andriucha ${ }^{77}$ ser um varapau, de Ássia ser uma insignificante e de eu ser uma gorducha - eu corria mais do que eles, mais do que todos: por puro sentimento de honra: chegar correndo e desabar. Eu gostava porque justamente o monumento de Púchkin foi a primeira vitória da minha corrida.

Com o monumento de Púchkin havia ainda uma brincadeira especial, uma brincadeira minha: depositar em seu pedestal a bonequinha branca de louça, miudinha, do tamanho do meu dedo mindinho - que era vendida nas lojas de louça, quem cresceu em Moscou no final do século passado se lembra, havia gnomos embaixo de cogumelos, havia crianças embaixo de guarda-chuvas, - depositar no pedestal do gigante uma bonequinha tão pequena assim e, aos poucos, percorrer com os olhos de baixo para cima toda a escarpa de granito, até ficar com torcicolo - e comparar o tamanho.

O monumento de Púchkin foi também meu primeiro encontro com o preto e o branco: tão preto! tão branca! - e visto que o preto era parecido com o gigante, e o branco era uma figurinha engraçada - e como se é obrigado a escolher, então eu escolhi, e escolhi para sempre, o negro e não o branco, o preto e não o branco: pensamentos negros, destino negro, vida negra.

0 monumento de Púchkin foi também meu primeiro encontro com os números: quantas dessas bonequinhas era preciso empilhar para fazer um monumento de Púchkin. E a resposta já era então a mesma de agora: "Por

\footnotetext{
${ }^{77}$ Hipocorístico de Andrei.
} 
mais que se empilhem..." - acrescentando com um orgulho-tímido: "Se tivesse cem de mim, então, talvez, até - dava, que eu ainda vou crescer..." E no ato: "E cem figurinhas uma em cima da outra, daria - eu?" Resposta: "Não, não porque eu sou grande, mas porque sou viva, e elas são de louça".

Desse modo, o Monumento-de-Púchkin foi também meu primeiro encontro com o material: o ferro fundido, a louça, o granito - e eu mesma.

O monumento-de-Púchkin, eu embaixo dele e a bonequinha embaixo de mim foi também minha primeira aula prática de hierarquia: eu diante da bonequinha sou gigante, mas eu diante de Púchkin sou eu. Isto é, uma menininha. Mas que vai crescer. Eu para a bonequinha sou o que o Monumento-de-Púchkin é para mim. Mas o que é então para a bonequinha o Monumento-de-Púchkin? E depois de me torturar com tanta pensação de repente fez-se a luz: é que ele para ela é tão grande, que ela simplesmente não o vê. Ela pensa - uma casa. Ou - um trovão. Mas ela para ele é tão pequena, que ele também simplesmente - não a vê. Ele pensa - não passa de uma pulga. Mas a mim - ele vê. Porque sou grande e gorda. E logo vou crescer mais ainda.

Primeira lição de números, primeira lição de proporções, primeira lição de matérias, primeira lição de hierarquia, primeira lição de idéia e, o principal, a confirmação prática de toda a minha experiência posterior: de mil bonequinhas ainda que empilhadas uma sobre a outra, não se faz um Púchkin. 
...Porque eu adorava descer de onde ele estava pela aléia de areia ou coberta de neve, pela aléia de areia ou coberta de neve voltar para ele para as suas costas e seu braço, para a sua mão nas costas, porque ele está sempre de costas, a partir dele - de costas ir para ele - que está de costas, de costas para tudo e para todos. E nós sempre passeávamos até as suas costas, assim como o próprio bulevar, com todas as três aléias, ia dar nas costas dele, e o passeio era tão longo que eu e o bulevar toda vez esquecíamos que cara ele tinha e cada vez ele tinha uma cara nova, ainda que igualmente negra. (Me dá uma tristeza pensar que as últimas árvores antes dele nunca souberam que cara ele tinha).

Do monumento de Púchkin eu gostava por seu negrume - o contrário da brancura dos deuses de nossos lares. Os olhos deles eram completamente brancos e os do Monumento-de-Púchkin - completamente negros, bem densos. 0 monumento-de-Púchkin era completamente negro, como um cachorro, mais negro ainda do que um cachorro, porque o mais negro deles tem sempre um pouco de amarelo acima dos olhos e um pouco de branco embaixo do pescoço. 0 monumento-de-Púchkin era preto como o piano de cauda. E se depois não tivessem dito que Púchkin era negro, eu saberia que Púchkin é negro.

É do monumento de Púchkin que vem todo o meu amor irracional pelos negros, um amor para a vida inteira, sinto até hoje todo o meu ser lisonjeado, quando, por acaso, num vagão de bonde ou em outro lugar, vejo um negro - ao meu lado. Minha indivindade branca lado a lado com a 
divindade negra. ${ }^{78}$ Em cada negro eu amo Púchkin e reconheço Púchkin - o negro monumento de Púchkin da minha infância ainda analfabeta e da Rússia inteirinha.

...Porque eu adorava que ele, enquanto nós estávamos sempre chegando ou saindo, estava sempre ali, saindo ou chegando, ele - sempre está. Sob a neve, sob as folhas esvoaçantes, no amanhecer, no céu, no leite turvo do inverno, está sempre - ali.

Às vezes, ainda que raramente, mudavam nossos deuses de lugar. Espanavam nossos deuses no Natal ou na Páscoa. Ele era lavado pela chuva e seco pelo vento. Ele estava sempre - ali.

O Monumento de Púchkin foi minha primeira imagem de integridade e imutabilidade.

- Para os Lagos do Patriarca ou...?

- Para o Monumento-de-Púchkin!

Nos Lagos do Patriarca, não havia nenhum patriarca.

\footnotetext{
${ }^{78}$ Assonância, no original, entre ubójiestvo (indivindade), bok o bok (lado a lado) e bójiestvo (divindade).
} 
Idéia maravilhosa - colocar um gigante no meio das crianças. Um gigante negro - no meio de crianças brancas. Idéia maravilhosa - consagrar crianças brancas ao parentesco negro.

Os que cresceram à sombra do Monumento de Púchkin não podem preferir a raça branca e eu - evidentemente - prefiro a negra. 0 monumento de Púchkin adiantando os acontecimentos é um monumento contra o racismo - em prol da igualdade racial, em prol da primazia de cada raça - desde que produza um gênio. O monumento de Púchkin é um monumento ao sangue negro que conflui no branco, um monumento à confluência dos sangues, como acontece - na confluência dos rios, o monumento vivo da confluência dos sangues, da mistura das almas dos povos - dos mais remotos e aparentemente - menos confluentes. 0 monumento de Púchkin é uma prova viva de que a teoria racista não passa de infâmia e morte, é uma prova viva de que só o seu contrário é verdadeiro. Púchkin é o fato que derruba a teoria. 0 racismo antes de se manifestar é derrubado por Púchkin no momento exato do seu próprio nascimento. Mas não, foi antes: no dia do enlace do filho do negro de Pedro, O Grande, Óssip Abrámovitch Hannibal, com Mária Aleksiéievna Púchkina. Mas não - antes ainda: num dia e hora desconhecidos para nós, quando Pedro deteve pela primeira vez sobre o garoto abissínio Ibrahim $^{79}$ um olhar negro, luminoso, alegre e terrível. Este olhar foi o decreto para Púchkin existir. Então as crianças que cresceram à sombra do petersburguês

\footnotetext{
79 Ver nota 5. Púchkin imortalizou seu bisavô materno, Abraham (Ibrahim) Petróvitch Hannibal, no romance inacabado que leva título de $O$ negro de Pedro, o Grande.
} 
Cavaleiro de Bronze, de Falconet ${ }^{80}$, também cresceram à sombra do monumento contra o racismo, em prol - do gênio.

Que idéia maravilhosa fazer negro o neto de Ibrahim. Fundi-lo em ferro como a natureza fundiu o bisavô na carne negra. 0 Púchkin negro um símbolo. Idéia maravilhosa - com o negrume da escultura, dar a Moscou uma nesga do céu abissínio. Pois o monumento de Púchkin está claramente "sob o céu da minha África"81. Idéia maravilhosa - a cabeça inclinada, uma perna mais à frente, o chapéu tirado da cabeça e levado às costas em sinal de reverência - dar a Moscou, aos pés do poeta, um mar. Pois Púchkin não se ergue por sobre o bulevar arenoso, e sim por sobre o mar Negro. Por sobre o mar de elementos livres - ergue-se o Púchkin de elementos livres.

Idéia sombria - colocar um gigante cercado de correntes ${ }^{82}$. Pois Púchkin ergue-se em meio a correntes, seu pedestal circundado ("cercado") de pedras e correntes: pedra - e corrente, pedra - e corrente, pedra - e corrente, um todo que o cerco - cerca. 0 cerco dos braços de Nicolau que nunca abraçaram o poeta e que sempre o cercearam. Um cerco começado pelas palavras: "Tu já não és o mesmo Púchkin, és o meu Púchkin"83, e que se rompeu apenas com o tiro de D'Anthès.

\footnotetext{
${ }^{80}$ Referência ao monumento eqüestre de Pedro, o Grande, esculpido por Étienne-Maurice Falconet (1716-1791), obra que inspira a Púchkin o poema longo intitulado "O Cavaleiro de Bronze" ("Медный Всадник").

${ }^{81}$ Verso do romance Evguiéni Oniéguin (Cap. 1, L, v. 11).

${ }^{82}$ Até ser transferido do bulevar Tvier para a praça Púchkin, o monumento era circundado por correntes de ferro.

${ }^{83}$ Referência ao episódio que se deu em 8 de setembro de 1826. Com a morte de Alexandre I e a subseqüente ascensão de Nicolau I, Púchkin, que se encontrava exilado em Mikháilovskoie desde 1920, decide escrever ao tzar uma carta solicitando seu retorno a S. Petersburgo. O tzar Nicolau I, então, convoca-o para uma audiência, na qual declara-se o único censor das obras do poeta.
} 
Nessas correntes, eu, e toda a Moscou da infância passada, presente, futuro, balançava-me sem suspeitar de nada. Era um balanço bem baixo, bem sólido, bem de ferro. - estilo Império? - estilo Império. - Empire ${ }^{84}$ - o Império de Nicolau I.

De pedras e correntes - mas é um monumento maravilhoso. 0 monumento à liberdade - ao cativeiro - aos elementos - ao destino - e à vitória final do gênio: de Púchkin ressurgido das correntes. Isso nós podemos dizer agora, pois a alteração feita por Jukóvski é uma vergonha para o homem e uma imperícia para o poeta:

Para sempre pelo povo serei lembrado,

Que da lira bons sentimentos despertava,

E fui útil por graça de versos alados...

com um prólogo a tal ponto não-puchkiniano, anti-puchkiniano, da utilidade da poesia - uma alteração que tem desonrado Jukóvski e Nicolau I por quase um século, uma desonra para todos os séculos dos séculos, que manchava o pedestal de Púchkin desde 1884 - ano de inauguração do

\footnotetext{
${ }^{84}$ Em francês, no original.
} 
monumento 85 , - que foi, finalmente, substituída pelas palavras do "Monumento"86 de Púchkin:

Para sempre pelo povo lembrado serei,

Que da lira bons sentimentos eu tirava,

E em tempos duros a liberdade eu cantei

E por clemência aos decaídos rogava. ${ }^{87}$

E se até agora eu não mencionei o escultor Opekúchin foi apenas porque existe uma glória maior - a anônima. Quem em Moscou sabe que o Púchkin é de Opekúchin? Mas o Púchkin de Opekúchin ninguém jamais esqueceu. Nossa aparente ingratidão é para o escultor - a mais alta gratidão.

E sou feliz por ter conseguido mais de uma vez recriar o rebento negro de Opekúchin - em palavras:

\footnotetext{
${ }^{85} \mathrm{Na}$ realidade, o monumento foi inaugurado em 1880.

${ }^{86}$ Referência ao poema "Exegi monumentum", de Púchkin, escrito em 1836 e publicado postumamente em 1841, com algumas alterações de Jukóvski em decorrência da censura. O texto original foi restabelecido em 1937.

${ }^{87}$ Estrofe IV de "Exegi monumentum".
} 
E lá nos campos sem fim

Servindo ao tsar do céu

O férreo bisneto de Ibrahim

Acendeu a manhã. ${ }^{88}$

E certa vez o monumento de Púchkin apareceu lá em casa para uma visita. Eu estava brincando na nossa fria sala branca. Estava brincando, ou seja - ora estava sentada embaixo do piano de cauda, a nuca na altura da jardineira de filodendro, ora, sem fazer barulho, corria do baú até o espelho, a testa na altura do aparador.

Tocaram, e um senhor atravessou a sala. Da sala de visitas para onde ele tinha ido, de repente, saiu mamãe, que me disse baixinho: "Mússia!89 Você viu esse senhor?" - "Vi". - "Pois então, é o filho de Púchkin. Você sabe o monumento de Púchkin, não sabe? Pois então: esse é o filho dele. É um tutor honorário. Fique aí bem quietinha, e quando ele passar de volta - você

\footnotetext{
${ }^{88}$ Estrofe do poema Чародею (“Ao feiticeiro”), de Marina Tsvetáieva, dedicado à sua irmã Anastássia Tsvetáieva. Trata-se de um ciclo de quinze poemas escritos de 15 de fevereiro a 4 de maio de 1914. A estrofe citada encerra o oitavo poema. Nesta obra, é evocada a amizade das irmãs por Lev Levóvitch Kabylínski (1874-1947), poeta e crítico literário mais conhecido pelo pseudônimo de Hellis. No original, a rima se dá entre o segundo e o quarto verso.

${ }^{89}$ Hipocorístico de Marina.
} 
olha. Ele é muito parecido com o pai. Você sabe quem é o pai dele, não sabe?"

O tempo passava. O senhor não saía. Eu ficava ali, olhando, e bem quietinha. Sentada sozinha na cadeira vienense, na sala fria, eu não ousava levantar, porque e se de repente - ele passa.

Ele passou - e bem de repente - não sozinho, mas com papai e mamãe, e eu não sabia pra onde olhar e olhava pra mamãe, mas ela capturou o meu olhar e brava lançou-o para o senhor, e eu consegui ver que ele tinha uma estrela - no peito.

- Então, Mússia, viu o filho do Púchkin?

$-\mathrm{Vi}$.

- Então, como ele é?

- Ele tem uma estrela no peito.

- Uma estrela! Tão pouca gente tem estrela no peito! Você tem um dom especial de olhar justamente o que deve ser olhado...

- Então, olhe, Mússia, lembre - retomou logo meu pai - que hoje, aos quatro anos de idade, você viu o filho de Púchkin. Mais tarde, há de contar isso aos seus netos.

Aos netos eu não demorei a contar. Não aos meus, mas ao único neto que eu conhecia - o da babá: o Vânia, operário da fábrica de estanho, que me presenteou com uma pomba de prata feita por suas próprias mãos. Esse Vânia, que vinha aos domingos por ser asseado e quietinho, e por respeito à 
babá, que ocupava entre nós uma posição privilegiada, tinha o direito de entrar no quarto de brinquedos, onde passava o tempo todo tomando chá com rosquinhas, enquanto eu, por amor a ele e ao passarinho dele, não desgrudava dali, sem dizer nada, engolindo quando ele engolia.

“Vânia, o filho do Monumento-de-Púchkin esteve aqui!”. - “O quê, senhorita?" - "O filho do Monumento-de-Púchkin esteve aqui e o papai falou pra eu contar isso a você." - "Bom, vai ver ele queria alguma coisa do paizinho e por isso veio..." - respondeu com incerteza Vânia. "Não queria coisa nenhuma, veio fazer uma simples visita ao nosso patrão", interrompeu a babá. - "Deve de ser um baita general" ${ }^{90}$ Sabe aquele Púchkin lá da Tvier?" - "Sei." - "Pois então, é o filho dele. Já é idoso, a barba toda branca, penteada em duas pontas. Vossa altíssima excelência."

Assim, por causa da distração da mamãe e da tagarelice da babá, e por papai ter mandado olhar e lembrar - palavras que em casa estavam ligadas aos objetos - o urso branco na galeria, o negro em cima da fonte, Mínin e Pojarsk ${ }^{91}$ etc. - e jamais a seres humanos, pois o tsar e João de Kronstadt que me levantando acima da multidão me mostravam, diziam respeito não a seres humanos, mas aos objetos sagrados - e o que ficou em mim foi isso: tínhamos recebido a visita do filho do Monumento-dePúchkin. Mas logo até mesmo o atributo incerto de filho desapareceu: o filho do Monumento-de-Púchkin virou o próprio Monumento-de-Púchkin. Tínhamos recebido a visita do próprio Monumento-de-Púchkin.

\footnotetext{
${ }^{90}$ Eneral, no original: corruptela de gueneral.

91 Alusão a estátua situada na Praça Vermelha, em Moscou, em homenagem ao príncipe Dimítri Pojárski e Kozmá Mínin, seu aliado contra Boris Godunóv (então tzar da Rússia).
} 
E quanto mais eu crescia, mais isto se firmava em minha consciência: o filho de Púchkin - por ser filho de Púchkin, já era ele mesmo um monumento. Um monumento duplo a sua glória e a seu sangue. Monumento vivo. É por isso que agora, toda uma vida vivida, posso dizer tranqüilamente que em nossa casa da Triokhprud, no final do século, em uma manhã branca e fria, veio o Monumento-de-Púchkin.

Assim, antes de Púchkin, antes de Don Juan, eu tinha o meu Comandante ${ }^{92}$.

Assim, também eu tinha o meu Comandante.

Ora, para ir, ou melhor, para ser conduzido à nossa casa da Triokhprud, o filho de Púchkin passava em frente à casa dos Gontcharóv, onde nasceu e cresceu a futura pintora Natália Sergueiévna Gontcharova ${ }^{93}$, sobrinha-neta de Natália Nicoláievna.

O filho legítimo de Púchkin passava em frente à sobrinha-neta Natália Gontcharóva que, talvez, naquele exato instante - sem saber nem reconhecer nem desconfiar - olhava pra ele da janela.

\footnotetext{
${ }^{92}$ Referência às obras dramáticas de Púchkin $O$ hóspede de pedra (Каменый гость) e Don Јиап (Дон Жуан), ambas de 1830.

${ }^{93}$ Em 1929, Tsvetáieva publica o longo ensaio "Natália Gontcharova" na revista Vólia Rossii (Praga).
} 
Nossa casa e a dos Gontcharóv - só fiquei sabendo disso em Paris, em 1928 - eram vizinhas, a nossa casa era a oito, e ela não lembrava o número da sua.

Mas qual era mesmo o segredo do quarto vermelho? Ah, a casa toda era misteriosa, a casa todinha era - um mistério!

O armário proibido. 0 fruto proibido. Este fruto - um volume, um enorme volume azul-violeta com letras douradas na diagonal - Obras Completas de A. S. Púchkin.

No armário da Valéria, minha irmã mais velha, mora Púchkin, aquele mesmo negro de cabelos encaracolados e com um brilho no branco dos olhos. Mas antes desse branco dos olhos - um outro brilho: dos meus próprios olhos verdes no vidro, porque esse armário era enganador - com duas portas de vidro - e se eu conseguisse em cada uma encaixar o nariz na divisória entre os vidros, então, refletem-se não os dois narizes nem sequer um - que se possa reconhecer.

O Púchkin grosso eu leio mergulhada no armário, quase metida no livro e na prateleira, quase no escuro e até um pouco sufocada pelo seu peso, que recai bem na minha garganta, e quase cega pela proximidade das letras minúsculas. Eu leio Púchkin com o coração e com o cérebro. 
Meu primeiro Púchkin - "Os ciganos"94. Eu nunca tinha ouvido nomes como Alieko, Zemfira - nem Velho. Velhos, eu conhecia apenas um - o Óssip do braço-fino do asilo de Tarussa - que tinha ficado com o braço-fino, porque matou o irmão com um pepino. Porque meu avô A. D. Mein não é um velho, porque os velhos são estranhos e vivem na rua.

Ciganos de carne e osso eu nunca tinha visto, mas desde que nasci ouvi falar de uma cigana, minha ama-de-leite que gostava tanto de ouro que quando lhe deram uns brincos de presente e ela percebeu que não eram de ouro, mas só dourados, ela os arrancou da orelha com carne e tudo, sapateando no chão.

Mas eis uma palavra completamente nova - amor. Quando se sente um calor dentro do peito, bem no fundo do peito (todo mundo sabe disso!) e quando não se diz nada a ninguém - é o amor. Eu sempre senti esse calor no peito, mas não sabia que isso - era amor. Eu pensava que com todo mundo era assim - sempre é assim. Acontece - só aos ciganos. Alieko é apaixonado por Zemfira.

E eu sou apaixonada - pelos ciganos: por Alieko, e também pela Zemfira, e pela tal Mariula, e pelo outro cigano, e pelo urso, e pelo túmulo, e pelas palavras estranhas nas quais tudo isso é contado. E sobre isso não posso dizer palavra: nem aos adultos - porque é roubado, nem às crianças porque as desprezo, mas principalmente - porque é segredo: meu - e do quarto vermelho, meu - e do volume azul, meu - e do fundo do peito.

\footnotetext{
94 “Os ciganos” (“Цыганы”): poema longo de Púchkin escrito de 1824 a 1825.
} 
Mas, no fim, amar e não dizer nada significa - explodir, e eu encontrara minha ouvinte, e duas até - nas pessoas da bá de Ássia, Aleksandra Múkhina, e da amiga dela, uma costureira, que vinha quando se sabia que minha mãe iria ao concerto e a ingênua Ássia estava - dormindo.

- E a nossa Mússienka95 é inteligente, sabe ler - falava a bá, que não gostava de mim, mas não perdia uma ocasião de me elogiar, quando todas as conversas sobre os patrões tinham acabado e tinham tomado todo o chá necessário. - Pois então, Múcienka, conte a do lobo e do cordeiro. Ou daquele (o tambor) ${ }^{96}$.

(Meu Deus, como cada um tem seu destino reservado! Eu, aos cinco anos, já era recurso espiritual de alguém. Falo isso não com orgulho, mas com amargura).

Então, uma vez, depois de criar coragem, o coração apertado, e engolir fundo97: - Eu posso contar de "Os ciganos".

- Ciganos? - a bá desconfiada - mas de que ciganos? E quem é que vai escrever um livro sobre eles que vivem de esmolas e têm mãos leves.

- Não é desses. É de outros. É um acampamento.

- Então, pois é um acampamento. Eles sempre acampam ao lado de uma casa senhorial, e, depois, vêm pra ler a sorte - a bruxa nova: "Vem cá, senhorita, deixa eu ver sua boa estrela..." - enquanto a bruxa velha - zás! e

\footnotetext{
${ }^{95}$ Hipocorístico de Marina.

${ }^{96}$ Trata-se do conto maravilhosos "O pequeno tambor".

${ }^{97}$ No original, aliteração entre glubok, ("fundo") e glotnut' (“engolir").
} 
lá se vão as roupas brancas do varal - ou o broche de diamantes da toalete da senhora.

- Não é desses ciganos. É de outros ciganos.

- Então, deixa, deixa ela contar! - a amiga, ao sentir as lágrimas na minha voz - vai ver que é mesmo de outros... Deixa ela contar, e nós vamos ouvir.

- Então, era uma vez um jovem. Não, era uma vez um velho, e ele tinha uma filha. Não, é melhor eu contar em versos. Ciganos em ruidoso tropel - Através da Bessarábia viajam - Eles hoje à beira do rio - Em tendas rotas pernoitam - Que liberdade alegre sua pousada - e assim por diante sem parar e sem vírgulas de permeio. - até: o retinir da bigorna ambulante $^{98}$, que, eu acho, deve ser um instrumento musical, e deve ser isso mesmo - acho eu.

- Como ela fala bem! Como se fosse num livro! - exclama a costureira, que gosta de mim em segredo, mas não demonstra, porque a babá é da Ássia.

- Um urso?! - fala a babá em tom de censura, repetindo a única palavra que ela tinha conseguido entender. - É verdade, um urso. Quando eu era pequena, os velhos contavam que os ciganos sempre punham os ursos pra dançar. "Vamos, Micha99, dance!” E ele dança-ava.

- Então, e depois, o que aconteceu? (A costureira).

\footnotetext{
98 Citação de versos da primeira estrofe de "Os ciganos", mais precisamente, os cinco primeiros e o décimo sétimo verso (em itálico).

${ }^{99} \mathrm{Na}$ Rússia, os ursos são em geral chamados de Micha.
} 
- E aí a filha vai até o velho e diz que esse jovem se chama Aleko.

A babá:

- Como?!

- Aleko!

- E isso lá é nome?! Um nome assim nem existe. Você está dizendo que ele se chama como?

- Aleko.

- Então, o Aleka é meleca.

- E você é burra. Não é Aleka, é Aleko!

- É o que estou dizendo: Aleka.

- Você que fala assim: Aleka, eu falo: Aleko, com o-o-o!!

- Então, está bem, está bem, Aleka.

- Aliócha - dizemos nós (a amiga, para fazer as pazes). - Tá, deixa ela contar, sua burra - é ela quem está contando, não você. Não fica brava com a babá, Múcienka, ela é burra, não tem estudo, mas você é estudada, é você que sabe.

- Então, essa filha se chamava Zemfira (em voz alta e ameaçadora:) Zemfira - a filha diz ao velho que Alieko vai morar com eles, porque ela o encontrou no deserto: 


\section{Encontrei-o no deserto vagando}

E convidei-o ao pouso cigano. ${ }^{100}$

E o velho ficou contente e disse para irmos numa mesma telega:

"Numa telega seguimos o curso - ta-ta-ta-ta, ta-ta-ta-ta - E nas aldeias mostramos o urso."101

- O urso - ecoou a bá.

- E assim viajaram, e depois, todos viveram muito bem, e os burros levaram as crianças nos cestos...

- Quem está nos cestos?...

- É assim: "Os burros com um cesto em cada flanco - Levavam crianças brincando - maridos e irmãos, mulheres, moças - E velhos e novos seguindo erravam - Gritos, barulho, ciganas canções - 0 rugido do urso e de seus grilhões"102.

A babá:

- E dá-lhe com esse urso! E com o tal velho o que aconteceu?

- Com o velho - nada, ele tinha uma jovem mulher, a Mariula, que o deixou por um cigano, e a outra, a Zemfira, também fugiu. No começo,

\footnotetext{
100 "Os ciganos" (II, vv. 7 e 8 ).

101 "Os ciganos" (III, vv. $9-12$ ).

102 "Os ciganos" (VI, vv. 11 - 16). Na citação feita por Tsvetáieva ocorre uma troca nos modos verbais; em vez de o verbo conjugado na terceira pessoa do presente tal qual aparece em Púchkin, a autor cita o verso com o verbo no indicativo. Seguimos o original de Púchkin a fim de atingir a métrica ideal para este poema, sempre tendo em vista que a alteração feita por Tsvetáieva não representa mudança no sentido nem na métrica do original puchkiniano.
} 
cantava sempre: "Marido velho, marido cruel! Eu não temo você!" - isso, ela cantava sobre ele, sobre o seu próprio pai, e depois fugiu também, e sentouse com o cigano no túmulo, enquanto Alieko dormia e roncava terrivelmente, e daí ele se levantou e também foi até o túmulo, e daí matou o cigano com a sua faca, e Zemfira caiu e também morreu. ${ }^{103}$

Ambas em uníssono:

- Ora, vejam só! Que malvado! Então foi uma facada mesmo?! E o velho fez o quê?

- 0 velho - nada, o velho disse: "Deixe-nos, homem orgulhoso!"104 - e partiu, e todos partiram, e todo o acampamento partiu, e Alieko ficou sozinho.

Ambas em uníssono:

- Bem feito pra ele. Matar só porque perdeu! Na nossa aldeia, também tem um que esfaqueou a mulher, - isso, Múcienka, não é pra você ouvir (cochichando alto) - pegou-a com o amante. E zás, uma facada pra ele e outra pra ela. Depois foi para as galés. Vassíli era o nome dele... É-é-é... Quanta desgraça há nesse mundo. E isso tudo por amor.

\footnotetext{
${ }^{103}$ Aqui, a pequena Tsvetáieva faz confusão entre a história contada a Alieko por Velho e o destino de Ziemfira e Cigano. Mariula era mãe de Ziemfira, a qual abandonou o marido e a filha ainda bebê. O episódio é narrado na décima oitava estrofe. Os versos citados entre aspas pertencem à vigésima estrofe e marcam o início do desinteresse de Ziemfira por Alieko. Já o destino trágico dos jovens amantes ocorre no fim do poema, mais precisamente entre a sexagésima e a octogésima estrofes.

104 "Os ciganos" (LXXXIII, v.2).
} 
Púchkin me contaminou com o amor. Com a palavra - amor. Pois é diferente: algo que não tem nome, - e algo que tem este nome. Quando a criada, ao passar, apanhou o gato fulvo que bocejava sentado na janelinha do vizinho, e ele depois passou três dias na sala de casa sob as palmeiras, mas depois foi embora e nunca mais voltou - isto é amor. Quando Augusta Ivánovna diz que vai-se embora para Riga para nunca mais voltar - é o amor. Quando o pequeno tambor partiu para a guerra e depois nunca mais voltou - é o amor. Quando na primavera espanam as bonecas parisienses de gaze rosada, cheias de naftalina, e depois tornam a guardá-las e eu fico olhando e sei que nunca mais as verei - é o amor. Ou seja, tudo isto - o gato fulvo, Augusta Ivánovna, o pequeno tambor e as bonecas, tudo isso provoca aquele calor lá no fundo, tal qual Zemfira e Alieko, e Mariula e o túmulo.

Mas o lobo e o cordeiro - não é amor, apesar de mamãe querer me convencer de que isso é muito triste.

- Você já pensou, um cordeirinho inocente e todo branco que nunca turvou água alguma...

- Mas o lobo - também é bonzinho!

Acontece que eu gostava do lobo por instinto, e nesse caso não dava pra gostar do lobo, porque ele comeu o cordeirinho, mas do cordeirinho apesar de tão branquinho e de ter sido devorado - eu não conseguia gostar, porque o amor não vinha, como nunca me veio para com os cordeiros. 
"Disse e arrastou o cordeiro para a mata cerrada"105.

Ao dizer lobo, eu dou nome ao Guia106. Ao dar nome ao Guia - eu nomeio Pugatchov: o lobo que daquela vez poupou o cordeiro, lobo que arrastou o cordeiro para a mata cerrada - para amar.

Mas de mim e do Guia, de Púchkin e Pugatchov ${ }^{107}$, falarei à parte, porque o Guia nos conduzirá para longe, talvez, para mais longe do que o alferes Griniov ${ }^{108}$, para onde o bem e o mal se embrenham, ali, no coração da mata em que eles emaranhados inextricavelmente e, emaranhando-se, formam uma vida viva.

Eu diria mesmo que eu gostava do Guia mais do que dos meus e dos desconhecidos, mais do que todos os meus cachorros preferidos, mais do que todas as bolas que rolaram para o porão e do que os canivetes perdidos, mais do que todo o meu secreto armário vermelho, onde ele era o principal mistério. Mais do que de "Os ciganos", porque ele era - mais negro do que os ciganos e mais sombrio do que os ciganos.

\footnotetext{
${ }^{105}$ Citação da fábula em versos O lobo e o cordeiro, de Ivan Andreiévitch Krylov (1769-1844), escrita em 1808.

${ }^{106}$ Título do cap. II de “A filha do capitão”. Nele, Pugatchov, sem revelar sua verdadeira identidade, serve de guia ao protagonista do romance, que havia se perdido na nevasca.

107 Púchkin e Pugatchov é o título de um outro trabalho em prosa de Marina Tsvetáieva dedicado a Púchkin, também de 1937. O ensaio foi escrito meses depois da conclusão de $M e u$ Púchkin e remete a duas obras de Púchkin inspiradas pela figura de Pugatchov: a biografia História de Pugatchov (История Пугачева, 1833) е о romance A filha do capitão (1836).

${ }^{108}$ Herói de $A$ filha do capitão, de Púchkin.
} 
E se a plenos pulmões eu conseguia dizer que no armário secreto vivia - Púchkin, hoje, é sussurrando a custo que eu digo: no armário secreto vivia... o Guia.

Sob influência contínua da leitura roubada, naturalmente, o vocabulário enriquecia-se.
\end{abstract}

- De qual boneca você gosta mais: a da tia de Nuremberg ou a da madrinha de Paris?

- A de Paris.

- Por quê?

- Porque ela tem olhos apaixonados.

Mamãe ameaçando:

- Como?!

- Eu, - me dando conta - Eu quis dizer: embasbacados.

A mãe ameaçando mais ainda:

- E mais essa!

Minha mãe não entendeu nada. Minha mãe entendeu o sentido e, quem sabe, indignou-se com razão. Mas entendeu - errado. Os olhos não 
eram - apaixonados, mas fui eu que atribuí aos olhos o sentimento de paixão despertado em mim por esse - olhar (e pelo véu rosado, e pela naftalina, e pela palavra Paris, e pelo caso do baú, e pela inacessibilidade da boneca). Não sou a única. Todos os poetas. (E depois duelam entre si porque a boneca não é apaixonada!) Todos os poetas, e Púchkin o primeiro.

Um pouco mais tarde - eu tinha seis anos, e este era meu primeiro ano de música - no conservatório Zógraf-Pláksina ${ }^{109}$, na travessa Merzliakóv, havia, como se chamava, então, festa pública - de Natal. Uma de "A Ondina"110, depois "Rognieda"111 - e:

Agora passemos ao jardim,

Onde com ele Tatiana se encontrou. ${ }^{112}$

\footnotetext{
${ }^{109}$ Alusão à antiga escola de música Zógraf-Pláksina, atualmente, Conservatório de Moscou.

${ }^{110}$ Ondina (Русалка): drama em versos de Púchkin bastante conhecido. Começou a ser escrito em 1828, mas ficou inacabado. Elisabeth Burgos em seu prefácio à Carta a la Amazona y otros escritos, relata que o conto homônimo de Friedrich de la Motte-Fouqué (1777-1843), escrito em 1811, era um dos preferidos de Marina Tsvetáieva em sua infância.

${ }^{111}$ Referência ao poema "Rognieda", de Kondrati R. Pyleiev, em 1827, baseado na história de Vladimir e Rognieda.

112 Evguiéni Oniéguin (cap. IV, XI, vv. 13 e 14.)
} 
Um banco. No banco - Tatiana. Daí, chega Oniéguin, mas não se senta, e ela se levanta. Ambos estão de pé. E só ele fala, o tempo todo, demoradamente, e ela não diz palavra. E nisso eu entendo que o gato fulvo, a Augusta Ivánovna, as bonecas, não são amor - que amor é quando: há um banco - ela se senta no banco, daí ele chega e fala o tempo todo, e ela não diz palavra.

- E então Mússia, do que foi mesmo que você mais gostou? - minha mãe, ao final.

- Tatiana e Oniéguin.

- O quê? Não foi de "A Ondina", onde tem o moinho e o príncipe e o silvano? Não da "Rognieda"?

- Tatiana e Oniéguin.

- Mas como é possível uma coisa dessas? E você lá entendeu alguma coisa? Afinal, o que é que você entendeu de tudo aquilo?

Silêncio.

A mãe, triunfante:

- Ahá, não entendeu patavina, tal como eu pensei. Ainda mais aos seis anos! Mas do que você podia gostar ali?

- Tatiana e Oniéguin.

- Você é uma perfeita idiota e mais teimosa do que uma mula! (Voltando-se para o diretor do conservatório que se aproximava, Aleksandr 
Leóntievitch Zógraf). Eu a conheço, agora, durante todo o trajeto no coche de praça, a todas as minhas perguntas, vai repetir: "Tatiana e Oniéguin!” Quase me arrependo de tê-la trazido. Nenhuma criança do mundo teria preferido "Tatiana e Oniéguin", todas prefeririam "A Ondina”, porque é um conto de fadas, algo compreensível. Eu realmente não sei o que vou fazer com essa menina!!!

- Mas, por quê, Múcienka, “Tatiana e Oniéguin”? - com muito carinho, o diretor.

(Eu, sem abrir a boca, curta e grossa:) "Por causa do amor".

- Ela com certeza já está no sétimo sono! - Nadiéjda Iákovlievna Briússova ${ }^{113}$, nossa melhor aluna e a mais velha, aproximando-se - e nisso, pela primeira vez, fiquei sabendo que existe um sétimo sono, como medida de profundidade do sono e da noite.

- E isso, Mússia, o que é? - pergunta o diretor, tirando do meu regalo uma tangerina que tinha sido posta ali, e de novo não dá pra ver (dá pra ver!) coloca, e de novo tira, e de novo, e de novo...

Mas eu já tinha calado a minha boca feito uma estátua, e nenhum sorriso de tangerina, dele ou de Briússova, e nem os terríveis olhares de mamãe podem arrancar de meus lábios - um sorriso de agradecimento. No longo caminho de volta - no silencioso trenó noturno - a bronca de minha mãe:

${ }^{113}$ Irmã de Valeri Briússov (N. do A.). 
- Que vergonha você me fez passar!!! Nem para dizer obrigada pela tangerina! Como você é tonta, aos seis anos, apaixonada por Oniéguin!

Engano de mamãe. Eu não estava apaixonada por Oniéguin, mas por Oniéguin e Tatiana (e, talvez, um pouquinho mais por Tatiana), por ambos, pelo amor. E mais tarde não escrevi nenhuma de minhas coisas sem estar apaixonada simultaneamente por ambos (por ela - um pouquinho mais), não por eles dois, mas pelo amor deles. Pelo amor.

Este banco, no qual eles não se sentaram, revelou-se determinante. Nem naquela época nem mais tarde, eu jamais gostei de quando se beijavam, sempre - de quando se separavam. Jamais - de quando se sentavam, sempre - de quando se apartavam. Minha primeira cena de amor foi de não-amor: ele não amava (isso eu entendia), por isso não tinha se sentado, ela amava, por isso tinha se levantado, eles não passaram juntos um instante sequer, não fizeram nada juntos, fizeram exatamente o contrário um do outro: ele falava, ela calava, ele não amava, ela amava, ele partiu, ela ficou, de modo que, se erguerem a cortina - ela continua lá, sozinha, e, talvez, sente-se de novo, porque ela estava em pé apenas porque ele também estava, mas daí ela desabou, e assim ficará sentada para todo o sempre. Tatiana está sentada naquele banco para todo o sempre.

Essa minha primeira cena de amor determinou todas as outras, toda essa paixão pelo amor infeliz, impossível, não correspondido. Desde aquele instante eu não quis mais ser feliz e me condenei ao - não-amor. 
O caso é que ele não a amava, e só por isso ela o amava - assim, e apenas ele escolheu para amar e não outro, porque intimamente ela sabia que ele não podia amá-la. (Isso eu digo agora, mas estava sabendo já naquela época, estava sabendo, e agora aprendi a dizer.) Aqueles que possuem este dom fatal do amor infeliz - unilateral, não correspondido - do amor tomado por si mesmo - parece que têm gênio para coisas inconvenientes.

Não só isso, mais que isso, determinou Evguiéni Oniéguin para mim. Se mais tarde, durante toda a minha vida, mesmo hoje, eu fui a primeira a escrever, a primeira a estender a mão - sem temer julgamento - é porque na aurora dos meus dias, Tatiana lá dentro do livro, à luz de uma vela, com a trança desfeita sobre o peito, tinha diante dos meus próprios olhos - feito. E se mais tarde quando partiam (e sempre partiam), eu jamais estendia a mão e nem virava a cabeça, é porque, então, no jardim, Tatiana tinha se transformado numa estátua.

Lição de coragem. Lição de orgulho. Lição de fidelidade. Lição de destino. Lição de solidão.

Que outro povo tem uma heroína do amor como esta: corajosa - e digna, apaixonada - e constante, clarividente - e afetuosa. 
Pois não há sombra de rancor - na recusa de Tatiana. Eis porque o castigo atinge Oniéguin em cheio, é por isso que ele fica "como que fulminado por um raio"114.

Ela tinha nas mãos todos os trunfos para vingar-se e levá-lo à loucura, todos os trunfos - para humilhar, pisotear a terra daquele banco, igualá-lo ao assoalho daquela sala, ela anulou tudo isso com apenas um deslize: "Eu o amo - por que hei de fingir?"115.

Para que fingir? Ora, para triunfar! E triunfar - para quê? E para isso, realmente, não há resposta clara para Tatiana - e de novo ela permanece no círculo mágico da sala, como então - no círculo mágico do jardim - no círculo mágico de sua solidão amorosa, então - desnecessária, agora almejada, e tanto então quanto agora - amante sem poder ser amada.

Tinha todos os trunfos na mão, mas ela - não jogava.

Sim, sim, moças, sejam as primeira a se declarar, e depois ouçam a recusa, e depois casem-se com os veteranos de guerra, e depois ouçam as declarações e recusem-nas - e vocês serão mil vezes mais felizes do que a nossa outra heroína, do que aquela, para a qual, de todos os desejos realizados, nada restou, a não ser deitar-se nos trilhos ${ }^{116}$.

\footnotetext{
${ }^{114}$ Verso de Evguiéni Oniéguin (cap. VIII, XLVIII, v. 2).

${ }^{115}$ Evguiéni Oniéguin (cap. VIII, XLVIII, v. 2). O verso faz parte da famosa carta de Tatiana a Oniéguin. No poema de Púchkin, o segundo hemistíquio (“por que hei de fingir?") aparece entre parêntesis.

116 Referência ao destino de Anna Karênina, personagem do romance homônimo de Lev Tolstói.
} 
Entre a plenitude do desejo e a realização dos desejos, entre a plenitude do sofrimento e o vazio da felicidade, minha escolha jamais foi feita - já estava feita antes de eu nascer.

Pois Tatiana, antes de mim, tinha influenciado também minha mãe. Quando meu avô, A. D. Mein, fez com que ela escolhesse entre ele e o bemamado, ela escolheu o pai e não o bem-amado, e casada acabou se saindo melhor do que Tatiana, pois "para a pobre Tânia todos os destinos eram iguais"117 - ao passo que minha mãe escolheu um destino mais difícil - com um viúvo duas vezes mais velho, com dois filhos, apaixonado pela falecida, casou-se pelos filhos e pela desgraça alheia, amando e continuado a amar aquele, com o qual depois nunca procurou encontrar-se e para o qual, ao encontrar pela primeira vez, e sem querer, numa palestra do marido, à pergunta sobre vida, felicidade etc., tinha respondido: "Minha filha tem um ano, ela é muito crescida e inteligente, eu sou plenamente feliz...” (Meu Deus, como nesse momento ela devia ter odiado a mim, inteligente e crescida, por não ser eu - filha dele!)

Desse modo, Tatiana não influi somente sobre toda a minha vida, como essa é a minha própria vida: se não existisse a Tatiana de Púchkin não existiria eu.

Pois é assim que as mulheres lêem os poetas, e não de outro modo.

É significativo, contudo, que mamãe não tenha me chamado de Tatiana, talvez, apesar de tudo - tinha tido pena da criança.

\footnotetext{
117 Verso de Evguiéni Oniéguin (cap. VIII, XLVII, v.v. 6 e 7). Tânia é hipocorístico de Tatiana.
} 


\begin{abstract}
Para mim, desde a infância até hoje, todo o Evguiéni Oniéguin reduzse a três cenas: a da vela - a do banco - a do assoalho. Alguns de meus contemporâneos conseguiam ver em Evguiéni Oniéguin uma farsa brilhante, quase uma sátira. Talvez, eles tenham razão, e talvez, se não o tivesse lido antes dos 7 anos... mas o li naquela idade, em que não existem nem farsas nem sátiras: existem jardins escuros (como em nossa casa de Tarussa), existe a cama desfeita e a vela (como em casa no quarto das crianças), existem assoalhos reluzentes (como na sala de casa) e existe o amor (como
\end{abstract} o eu tenho no fundo do peito).

A vida cotidiana? ("A vida cotidiana da nobreza russa da primeira metade do século XIX".) É preciso que as pessoas estejam vestidas, não é?

Depois do secreto Púchkin azul-violeta, apareceu-me um outro Púchkin - que já não era furtado, mas presenteado, não era secreto, mas revelado, não era azul-grosso, mas azul-fino - inofensivo, domesticado, o Púchkin das edições para as escolas municipais com um menino negro que apoiava a maçã do rosto no pulso. 
Nesse Púchkin, eu gostava apenas do menino negro. A propósito, esse negro retrato de criança é, para mim, até hoje, o melhor dos retratos de Púchkin -, o retrato de sua longínqua alma africana, e de sua ainda adormecida - alma de poeta. 0 retrato em duas direções - para trás e para frente, o retrato de seu sangue e de seu gênio futuro. Um menino desses seria o segundo escolhido de Pedro assim como outrora ele tinha escolhido um primeiro.

Eu não gostava desse livrinho, era um Púchkin diferente, nele até os “Os ciganos” eram diferentes, sem Alieko, sem Zemfira, só com o urso. Era o amor secreto sendo revelado. Mas, além do conteúdo, o próprio título já causava repugnância: para as escolas municipais, o que expunha algo mau, descarnado e abatido, ou seja, rostos de pobres - os rostos dos alunos das escolas municipais: famintos, sujos, azuis de frio, como o próprio Púchkin rostos que despertariam piedade não fosse o par de punhos ameaçadores do ódio de classes, rostos, que a despeito dos punhos, provavelmente, despertariam piedade em alguém, mas não podiam despertar amor. Descarnados, azuis e maus. Dois punhos. Enlaçando a barriga cavada - o cinto com a enorme fivela amarela das escolas municipais. 


\section{O passarinho de Deus não conhece}

Nem a previdência nem o lavoro,

E por isso inquieto não tece

O seu ninho para ser duradouro. ${ }^{118}$

O que ele está fazendo, então? E quem, então, está fazendo o ninho? E existem desses passarinhos além do cuco, que não é um passarinho, mas, sim, um verdadeiro passarão? Esses versos falam, evidentemente, de uma borboleta.

Mas a força da melodia poética é tanta que, por mais de cem anos, ninguém pensou em corrigir esse passarinho - e eu menos ainda - nos meus seis anos - à época. Já que está dito assim, assim é! Nos versos é assim. Esse passarinho é uma liberdade poética. Interessante, o que acham desse passarinho os ajuizados escolares da Rússia Soviética?119

"Inverno, o camponês em festa"120, página dois do Púchkin para os escolas municipais, eu gostava mais ou menos, gostava (um poema!), mas como lá em casa, como Augusta Ivánovna quando pára com suas ameaças de ir-se embora para Riga. Tudo era muito parecido. "De tulupe, de cinturão vermelho" - é o Andriúcha, e "o camponês em festa” - o guarda, e o trenó de

\footnotetext{
${ }^{118}$ Verso do poema "Os ciganos" (VIII, vv. 1-4).

119 Trecho suprimido das edições soviéticas até 1980.

${ }^{120}$ Evguiéni Oniéguin (cap. V, II, v. 1).
} 
carregar lenha - a lenha ${ }^{121}$, e a mamãe - a nossa mamãe, quando nós, à espera do passeio ao Monumento-de-Púchkin com a babá, comemos neve ou lambemos gelo. Os versos também despertavam a inveja, porque nós nunca brincávamos no pátio - apenas o atravessávamos - por que vai saber se os filhos do Andrei (da família que alugava uma ala da casa) não tinham escarlatina? 0 totó nós não colocávamos no trenó - mas tinha um trenó azul, aveludado, com tachas (olhos) de ouro-velho. E, além do que foi dito, "Inverno, o camponês em festa" era uma fábula com aparência de poesia, que sob aparência de poesia - era prosa e a qual eu, a cada nova antologia, sempre deixava para - ler por último. Hoje eu diria: "Inverno, o camponês em festa" é um idílio, ou seja, esse mesmo amor feliz, cujo sentido, finalidade e plenitude eu nunca cheguei a entender.

Para pôr um ponto-final nesse Púchkin azul das escolas municipais: era extremamente magro para o amor, - nenhum esforço para erguê-lo, para, depois de uma respiração profunda, apertá-lo contra o avental sempre-suíço e sempre-apertado, - nada nas mãos e nada para os olhos: apenas o já lido.

As coisas e os livros, e mais tarde os filhos, os meus e os dos outros, eu amava e amo - também por seu peso. Mesmo hoje, ao ouvir a respeito de uma nova obra bastante comentada: "Mas é longa?" - "Nada além de uma pequena novela." - "Então, nem vou ler."

\footnotetext{
121 Em russo, jogo de palavras entre dróvni (trenó campestre destinado ao transporte de madeira), dróva (lenha) e dvórniki (guarda).
} 
A antologia do Andriúcha era indubitavelmente-grossa, recheada por Bagrov-neto e Bagrov-avô ${ }^{122}$, e a mãe febril que resfolega bem no peito da criança, e todo o amor irracional dessa criança, e esses baldes de peixes pescados pelo jovem pai aparvalhado, e "Você ainda não está dormindo?"123 - e o Nikoliénka ${ }^{124}$, recheado de todos aqueles temas de galgos e afghans, e todos os poetas líricos da Rússia.

Da antologia do Andriúcha eu logo fui me apossando: ele não gostava de ler, aliás, não suportava, mas ali era preciso não só ler, mas também estudar, e copiar, e compor com as próprias palavras, eu ainda não ia à escola, era livre, e para mim a antologia era - só amor. Mamãe não se incomodava: era uma antologia - que nada tinha de prematura. Toda a literatura é precoce para as crianças, pois toda ela fala de coisas que as crianças não sabem e nem podem saber. Por exemplo:

Quem com estrelas e lua no céu

Assim tão tarde vai em seu corcel?

(Andriúcha, à pergunta de mamãe: "E eu é que vou saber?")

\footnotetext{
122 Personagens dos livros autobiográficos Семейная хроника (Сrônica familiar) е Детские годы Багрова-внука (A infância de Bagrov-neto), de S. T. Aksakov (1791-1859).

123 Referência a uma antiga canção popular russa.

${ }^{124}$ Referência à obra Infância, de Lev Tolstói. O protagonista da história (em parte, um alterego do jovem Tolstói) chama-se Nikoliénka Irteniev.
} 


\section{...Por que o gorro tanto valoriza?}

Porque nele há a denúncia cerzida.

\section{Denúncia contra Hetman-malfazejo}

Daquele Kotchubei ao Tsar-Pedro. ${ }^{125}$

Não sei das outras crianças, mas eu, que da quadra inteirinha entendi apenas o malfazejo e que aqui está circundado de três nomes, então, tomei por malfazejo - os três: Hetman, Tsar-Pedro e Kotchubéi, e não conseguia entender (e agora não entendo completamente) que malfazejo - só há um e quem é ele exatamente. Para mim, Hetman é até hoje - Kotchubéi e TsarPedro, e Kotchubéi é até hoje - Hetman, etc., e os três tornaram-se um, e esse um é o malfazejo. O que é denúncia, claro, eu também não teria entendido, e mesmo se tivessem me explicado, não teria entendido, no meu íntimo não teria entendido, como ainda hoje não entendo - o motivo de se escrever uma denúncia. Então, ficava assim: o cossaco está voando num céu claro, transparente (onírico!), onde ao mesmo tempo (nunca acontece!) há estrelas e lua, e o cossaco está voando salpicado de estrelas e banhado de luar - como para que o vissem melhor! - e na cabeça dele há um gorro, e

\footnotetext{
${ }^{125}$ Trecho do drama em versos Poltava (Полтава), poema longo que Púchkin escreveu de 3 a 13 de outubro de 1828. O tema da obra é a Batalha de Poltava, uma das mais famosas batalhas da Grande Guerra do Norte (1700-1721), e a narrativa gira em torno de Vassíli Leontievitch Kotchubéi (1640-1780) e de seu principal oponente, Ivan Stiepanovitch Mazepa (1639-1709), hetman da Ucrânia de 1687 a outubro de 1709. Os versos citados por Tsvetáieva encontram-se na primeira das três partes que compõem o poema, mais precisamente, nas quadras XXVI e XXXI. Os dois primeiros versos citados por Tsvetáieva são os últimos versos da estrofe XXVI. Para a epígrafe de Poltava, Púchkin escolheu uma quadra do poema homônimo de Byron, o épico Mazeppa (1819), em que o herói, uma representação do espírito romântico, é justamente o hetman Ivan Mazepa.
} 
nesse gorro tem uma coisa desconhecida, denúncia - a denúncia contra um Hetman-malfazejo da parte de Kotchubéi ao Tsar-Pedro.

Esse foi meu primeiro contato com a história, e essa primeira história histórica foi - de uma malfeitoria. E eu diria mais: quando na época da guerra civil eu ouvia Hetman (com o epíteto: Skoropádski), logo via aquele cossaco - que está caindo ${ }^{126}$.

Mas com o Tsar-malfazejo eu tive ainda um outro encontro antológico: "Quem é ele?" E de novo a mamãe ao Andriucha: “Então, Andriucha, quem é ele?" E de novo o Andriucha com dignidade, tristeza e até mesmo revolta: "E eu é que vou saber?" (Estranho mundo este - o da poesia, em que os adultos perguntam e as crianças respondem!) "E você, Mússia? Sabe quem é ele?" - “Um Gigante". - "Por que um Gigante?" "Porque ele consertou de vez". - "Mas o que significa 'E de Pedro para a felicidade'?" - "Não sei". - “Diga, o que significa de Pedro?” (Nada na cabeça, a não ser a grafia depedro") "Você não sabe o significado de: de Pedro?" "Não". - "E o que é do Andriúcha, você sabe?" - "Sei, o cavalinho de balanço ${ }^{127}$ do Andriúcha, a bicicleta do Andriúcha, o trenó do Andriúcha..." “Tá bom, tá bom. Então, de Pedro é a mesma coisa. De Pedro. Você entende, agora, o que significa de Pedro? E o que é felicidade - você sabe? (Silêncio.) Você não sabe o que é felicidade?" - "Eu sei. Felicidade é quando nós estamos voltando do passeio e de repente o vovô chega, e também quando eu achei na minha cama..." - "Chega. Para de Pedro a felicidade significa

\footnotetext{
${ }^{126}$ Referência a P. P. Skoropádski. Em russo, skoro significa "rápido" e pádski provém do verbo padat', que quer dizer "cair".

${ }^{127}$ No original, palavra alemã transliterada para o russo que significa "cavalo de balanço".
} 
para a felicidade de Pedro. E que Pedro é esse?" - "Eh..." “Quem é ele? Então?" - "Mas é o hóspede maravilhoso. Olha demoradamente para aquela direção. Onde o hóspede maravilhoso acabou de sumir..." - "E como se chama este hóspede maravilhoso?". Eu, timidamente: "Seria Pedro?" - "Mas, claro, graças a Deus!.. (Com uma desconfiança repentina.) Mas Pedros existem muitos. E esse que Pedro é? (E sem esperanças numa resposta:) É aquele mesmo Pedro que...

Denúncia contra Hetman-malfazejo

Daquele Kotchubéi ao Tsar-Pedro.

\section{Entendeu?"}

Claro que sim! Mas é uma pena! Tão logo Pedro começou a se revelar, novamente foi lançado àquela noite de brilho-profundo, de estrelas e de lua, de cossacos a galope, desse gorro, daquela denúncia e, o que é ainda pior, era como se este Pedro que consertou o barco do velho tivesse feito uma boa ação, e não passava daqueles mesmos malfazejos, Kotchubéi e Hetman. E de novo - na lua-nova! - ficou um gigantesco ponto de interrogação: “Quem?" Quando se trata de Pedro, é sempre: quem? Pedro é quando não se sabe a resposta.

Mas também o contrário: mal uma pergunta ressoava nos versos, logo a desconfiança caia sobre Pedro. 
Por que há salvas de tiros e gritos

Nesta cidadela de Petersburgo? ${ }^{128}$

A resposta: “Claro, é por causa do Pedro!". Mas o que ele fez exatamente, pois todas as respostas sopradas não são respostas. E principalmente uma assim, que até chega a ser ridícula:

Tinha parido Ekaterina?

Era o dia do seu santo

Do gigante-taumaturgo

A esposa de negras sobrancelhas ${ }^{129}$

Parido, eu não entendia, só entendia nascido ${ }^{130}$, e nem de nenhuma Ekaterina, esposa de Pedro, tinha ouvido falar, e o taumaturgo era São Nicolau, o Taumaturgo, ou seja, velho e santo, que não tinha mulher. Mas na poesia ele - tem. Portanto, é um taumaturgo casado.

\footnotetext{
${ }^{128}$ Citação de “O Banquete de Pedro I” (“Пир Петра Первого”), de Púchkin, escrito em 1935. Marina Tsvetáieva inverte a ordem entre o segundo e o terceiro versos da segunda estrofe do poema: "O que festejam pelo grande tsar/Na cidadela de Petersburgo?/Por que há salvas de tiros e gritos/E a esquadra a postos no rio?

${ }^{129}$ Versos de "O Banquete de Pedro I" (IV, vv. 5-8).

${ }^{130}$ Em russo, rodilá ("parido") e rodilás ("nascido").
} 
Mas, meu Deus, que alívio, quando depois de tantos porquês e tantas respostas evidentemente falsas, - finalmente, o bem-aventurado porque! "Eis porque tanto barulho e gritos - na cidadela de Petersburgo"131.

Só agora, repassando passo a passo o Púchkin da minha infância, vejo o quanto Púchkin gostava de recorrer a perguntas: "Por que salva de tiros e gritos? - Quem é ele? - Quem com estrelas e a lua no céu? - E os montenegrinos, o que são?" - etc. Se, naquela época, eu acreditasse mesmo que ele de fato não sabia, era possível pensar que o poeta de todas as pessoas é aquele que nada sabia, tanto que perguntava até para mim, uma criança. Mas a criança irritada desconfiava que era - de propósito, que ele não pergunta, ele sabe, e desconfiando que ele queria me pegar, e sem acreditar em nada do que me sugeriam, eu via cada poesia livremente linha por linha, como sabia, do meu jeito, eu via. Devo ao Púchkin histórico da minha infância minhas mais inesquecíveis visões.

Mas não posso, da minha pessoa de então e de agora, não dizer que a pergunta nos versos é um recurso irritante, pelo menos porque cada por que exige e promete um porque e isso enfraquece o próprio valor de todo o processo, toda a poesia se converte em um período, concentrando nossa atenção para o objetivo final exterior, que o poema não deve fazer. A pergunta insistente converte o poema em enigma com resposta, e se todo o poema é em si mesmo um enigma e uma resposta, a resposta a este enigma não é dada, para aquilo que este enigma propõe não há resposta alguma.

${ }^{131}$ Citação de "O Banquete de Pedro Primeiro" (VI, vv. 1 e 2). 
Mas, em "0 afogado"132 - não há sombra de perguntas. Em compensação, há surpresas. Em primeiro lugar, aquelas crianças, ou seja, nós que brincamos sozinhos no rio, em segundo, nós que vulgarmente chamamos o nosso pai: papá! e em terceiro, nós que não temos medo de morto. Porque elas não gritam amedrontadas, mas alegres e até cantarolando, assim: “Papá! Papá! Veja as nossas redes! Elas trouxeram até nós! Um morto!" - “É mentira de vocês, capetinhas, uma mentira - rabujou o pai. - Ah, e ainda dizer qu'eu os fiz! Ora essa, vejam qu'obra: um morto!" Este morto-qu'obra era, claro, um pouquinho cobra, a cobra que, por ser uma poesia, era chamada de qu'obra. Eu falo: um tanto cobra, a cobra sobre a qual nunca parei para pensar e, por causa dessa imprecisão absoluta, eu gritava bem alto, entoando assim: "Ora essa, vejam qu'obra-um-morto!"133 Se naquela época tivessem me perguntado, o quadro concebido seria aproximadamente este: na terra vivem cobras e mortos, e o nome deste morto é Qu'obra, porque ele tem alguma coisa de cobra, já que foi enterrado perto das cobras.

A cobra eu conheci em Tarussa, em Tarussa também conheci os afogados. No outono, nós por muito, muito tempo, até as precoces noites escuras e até as tardias manhãs sombrias ficávamos em Tarussa, na nossa datcha solitária - a duas verstas de qualquer habitação - tendo como único vizinho (para nós - bastava um minuto para descer, para eles - um minuto para subir) o rio - Ocá (“Está dando poucos peixes no rio!”), - mas, não só os peixes, porque no verão alguém sempre se afogava, quase sempre, os

\footnotetext{
132 "O afogado" (“Утопленник”, 1928), de Púchkin.

133 "O afogado" (I, vv. 7 e 8).
} 
meninos - de novo engolidos pela balsa - e, quase sempre, também os bêbados, e, quase sempre, também os sóbrios, - e uma vez até o balseiro afundou, e ali também o vovô Aleksandr Danílovitch ${ }^{134}$ morreu, e mamãe e papai foram para a missa de quarenta dias ${ }^{135}$ e lá ficaram por causa do testamento, e apesar de eu saber que isso é pecado - porque o vovô gostava mais de mim do que da Ássia, e tolice - porque o vovô nem sequer morreu afogado, mas morreu de câncer - de câncer? Só que:

E foi então que no corpo inchado

Os cânceres negros aferroaram!136

...resumindo, através da porta de vidro da sala de jantar - nas colunas fantasmagóricas do balcão e embaixo delas, trazendo todo o rio atrás de si:

Desde manhã o mau-tempo braveja

Vem a noite e a tempestade gela,

Chega então o afogado que golpeia

Lá no portão e também na janela. ${ }^{137}$

\footnotetext{
${ }^{134}$ Referência a A. D. Mein.

${ }^{135}$ Referência ao ritual da igreja ortodoxa russa de celebrar uma missa após quarenta dias da morte de alguém. Em russo, a celebração recebe o nome de sorokovói (сороковой).

${ }_{136}$ Citação dos dois últimos versos da oitava estrofe de "O afogado".

137 "O afogado" (VIII, vv. 7 e 8).
} 
O morto-qu'obra com o duplo rosto do vovô Aleksandr Danílovitch e do balseiro que afundou.

Em compensação, um outro poema de terror, "Vurdalak"138, não tinha nada de assustador, a não ser pelo fato de Vânia logo se revelar um tanto covarde e desde a primeira linha - com o seu suor e pálido de pavor desperta desprezo, que, como se sabe, cura todas as paixões, até a mais forte delas (para mim) - a paixão do pavor. “Quem certamente rói os ossos é o vurdalak ${ }^{139}$ de beiços vermelhos". Quem mais que rói ossos? 0 cachorro. 0 vurdalak é um cachorro de beiços vermelhos. Um cachorro negro (porque é noite) de lábios vermelhos. E o tolo (o coitado) assustou-se. Todo o efeito do medo perdia-se nesses ossos roídos, já que uma criança não pode deixar de associar com um cachorro. 0 aterrorizante vurdalak logo se transforma naquele cachorro que em Púchkin revela-se apenas na última linha, ou seja, nem por um instante ele é um vurdalak. Desse modo, todo o terror se concentra na palavra vurdalak, ou seja, o título do poema. Claro, a palavra vurdalak é desagradável (um tanto lambão), e o tal cachorro não é lá muito canino - caso contrário não se chamaria vurdalak, e seus lábios vermelhos, que dava pra ver até de noite, são duvidosos, e sua ocupação - levar ossos justamente para um túmulo é meio torpe, mas nada disso justificava aos meus olhos o medo de Vânia. Se Vânia estivesse atravessando o cemitério sem um cachorro - isto, sim, seria aterrorizante. Mas um cachorro, ao

\footnotetext{
138 "Vurdalak" (Вурдалак), poema de Púchkin que faz parte do ciclo "Canções dos eslavos do norte" (“Песни западных славян"), de 1834.

${ }^{139} \mathrm{O}$ vurdalak, personagem folclórico de alguns povos eslavos, é uma espécie de vampiro.
} 
contrário, é uma alegria. (Como em "Vii"140, onde o terror só existe na solidão de Khomá com a defunta e onde o terror - com a aparição de Vii ${ }^{141}$ e, depois, dos outros demônios ${ }^{142}$ - desfaz-se. Onde há muita gente tem sempre alegria.)

Ora, o cachorro é estranho, suspeito, e o Vânia, está claro, é um tolo rematado - e um coitado - e um covarde. E ainda - malvado: “Imaginem só a cólera de Vânia!" E imaginamos mesmo: ou seja, Vânia no mesmo instante dá um pontapé no cachorro. Porque é malvado... Pois para uma criança que se preze não há maldade maior do que bater em um cachorro: melhor matar a governanta. 0 menino malvado e o cachorro - com essa dupla, a ação está garantida.

E terminava, como sempre, como tudo que se ama termina - com lágrimas: um cachorro bom, castanho-acinzentado, um tantinho preto, com os lábios um tanto vermelhos, tinha roubado um osso na cozinha e fora com ele para o túmulo, para que a cozinheira não o tomasse, de repente, um covarde qualquer, o Vânia, estava passando por ali e deu-lhe um pontapé. No maravilhoso focinho úmido. U-u-u... ${ }^{143}$

\footnotetext{
${ }^{140}$ Referência ao conto de N. V. Gógol, "Vii" (1835), da antologia Mirgorod, escrito de 1833 a 1842 .

${ }^{141}$ Vii (em russo "Вий” е em ucraniano "Вiï ”): ser fantástico presente nas lendas da Ucrânia, um ancião de pálpebras e sobrancelhas que se estendem até o chão. Quando abre suas as pálpebras, o Vii é capaz de reduzir a cinzas as pessoas para as quais dirige seu olhar.

${ }^{142}$ No conto de Gógol, Vii é o rei dos demônios que o acompanham.

143 No original - “чудуную моркую морду" (tchudunuiu morkuiu mordu/ "no maravilhoso focinho úmido") - anadiplose iniciada no primeiro adjetivo e reforçada através do uso do caso acusativo dos nomes femininos com a intenção de reproduzir o uivo do cachorro.
} 
Mas o meu preferido entre os aterrorizantes, o mais aterrorizante por afinidade e o mais afim por aterramento era - "Os diabos"144. "Nuvens passam rodopiantes encobrindo toda a lua..."145

Tudo é aterrorizante - desde o começo: a lua não pode ser vista, mas ela - existe, a lua está encoberta, a lua de chapéu de mágico ${ }^{146}$ para tudo ver e para não ser vista. Poema estranho (situação), em que ao mesmo tempo é possível ser (é impossível não ser) tudo: lua, cavaleiro, cavalo que refuga e - oh, um doce estarrecimento - eles! Pois não há leitor que imediatamente não se sente no trenó e não voe por sobre o trenó, que lá, na amplitude infinita, não uive para vozes estranhas e que lá, no trenó, não estremeça de medo dos uivos. Dois vôos: o do trenó e o das nuvens e em cada um tu voas. Mas, além do que viajava e dos que voavam, eu era também uma terceira: aquela que mesmo encoberta vê: Púchkin, acima dele - os Diabos, e sobre Púchkin e os Diabos - a lua vaga.

Medo e piedade (também cólera, também nostalgia, também desejo de proteção) foram as principais paixões da minha infância e lá, onde não havia alimento para elas - eu não existia. Mas que piedade, diferente daquela que eu sentia em "Vurdalak", invadia-me em "Os diabos" e pelos diabos! Pelo cachorro eu sentia uma piedade - uterina: a baixa e quente piedade compassiva do ventre, a piedade - da proteção: matar Vânia, matar a cozinheira e dar o fogão inteirinho com suas frigideiras e panelas e, talvez, até o próprio Vânia em carne e osso para o cachorro comer. Pelos

\footnotetext{
144 “Os diabos” (“Бесы”), poema de Púchkin escrito em 1830.

${ }^{145}$ Versos de "Os diabos" que abrem o poema e, em seguida, repetem-se nas estrofes IV e VII.

${ }^{146}$ Nos contos maravilhosos, chapéu que faz ficar invisíveis as pessoas que o usam.
} 
diabos havia uma piedade elevada, uma piedade que é enlevo e reconhecimento, como a piedade que eu senti, depois, por Napoleão em Sta. Helena e Goethe em Weimar. Eu sabia que "...será pelo duende que enterram? Ou seria pela bruxa que casam?"147 - era apenas para dizer que não estavam enterrando nem casando ninguém, de qualquer modo vão se lamentar porque enterram um vovô ou casam uma moça - para se lamentarem melhor. Pois não é por isso que eles se lamentam, mas porque eles são eles e nunca serão outros, nem podem ser. (Cochichando: "porque Deus os amaldiçoou!") 0 amor por quem foi amaldiçoado.

E mais: eu sabia que eles são as nuvens! Que são cinzas, macios, que, de certa forma, nem existem, que não dá pra tocar, não dá pra abraçar, que entre eles, com eles, consigo, pode-se apenas rodopiar! Que é o vento que uiva! Que nem existem.

"Nos nevoeiros ondulados, eis que a lua se revela..."148 - de novo se revela como uma gata, como uma ladra, como uma loba imensa no rebanho de carneiros adormecidos (carneiros... nevoeiros...). "Sobre as clareiras, ela derrama sua triste luz..."149 Oh, Deus, como é triste, como é duas vezes triste, como é irremediavelmente, desesperançosamente triste, como é para sempre marcada - com a tristeza, como se com essa repetição Púchkin

\footnotetext{
147 Versos finais da sexta estrofe de "O diabo".

148 Citação dos dois versos iniciais de “Caminho invernal” (“Зимняя дорога”), роеma de Púchkin escrito em 1826 e composto por sete estrofes de quatro versos.
} 
tivesse imprimido a lua na clareira. Quando cheguei em: "Ouço algo familiar nas livres ${ }^{150}$ canções do cocheiro"151, - então, fui cair em:

Vocês, olhos, olhos azuis,

Arruinaram um jovem para quê?

Oh, esse povo, que povo ruim

Separaram corações para quê?

E esses olhos azuis eram de novo a lua, como se a lua dessa vez olhasse com dois olhos, e eu não demorei a saber que eles estão embaixo das negras sobrancelhas da bem-amada, que pode ser aquela mesma pela qual choram os diabos, porque a davam em casamento.

Leitor! Eu sei que "Vocês, olhos, olhos azuis" - não é de Púchkin, mas de uma canção, talvez até de uma romança, mas, naquela época, eu não sabia disso e, agora, dentro de mim, onde há tudo - ainda é tudo, também não sei, porque "rasgando o meu coração" e "a saudade do coração"152, pequena diabinha e bem-amada, estrada e estrada, separação e separação, amor e amor é uma coisa só. Tudo isso se chama Rússia e minha infância, e se vocês abrirem a minha barriga, além de diabos passando com nuvens e nuvens passando com

\footnotetext{
149 “Caminho invernal”(I, vv. 3 e 4).

${ }^{150}$ No original de Púchkin, verifica-se "longa" no lugar de "livre".

151 "Caminho invernal" (III, vv. 1 e 2).

${ }^{152}$ Último verso da terceira estrofe de "Caminho de inverno".
} 
diabos, vocês também descobrirão em mim aqueles dois olhos azuis. É a minha essência.

"Oh, boa amiga das horas amargas - Oh, minha pombinha encanecida!" ${ }^{\prime 153}$ - como isso não se parecia com a babá de Ácia, nem moça nem velha, com o sobrenome sórdido Múkhina ${ }^{154}$, como isso se parece com a minha babá, aquela que eu gostaria de ter tido e que não tive. E como isso se parecia com o nosso cinza-azulado quintal de pombas, que bicava e arrulhava, que bicava e barulhava. (Minha babá teria sido - pombinha e a de Ácia - Múkhina.)

A palavra pombinha eu conhecia, pois era assim que papai sempre chamava minha mãe - ("Você não acha, pombinha? - Você não acredita, pombinha? - Que Deus os proteja, pombinha!") - e fora pombinha não a chamava de outro nome ${ }^{155}$, mas, amiga era nova, eu e Ácia crescemos solitárias, e não tínhamos amigas. A primeira vez que ouvi a palavra amiga - a mais amorosa de todas - foi para referir-se a uma velha. "Oh, boa amiga das horas amargas - Oh, minha pombinha encanecida!" Pombinha encanecida - quer dizer com muitas penas, fofa, quase uma pombinha de pelúcia, quase um regalo - a pombinha, que parecia com o regalo de pele de lontra da mamãe, seria branca, e Púchkin assim chamava sua babá, porque a amava. Se digo: amiga, digo: pombinha - e começa a doer.

De quem eu tinha pena? Não da ama. De Púchkin. A saudade que ele sentia da ama, transformava-se em saudade dele, que se sentia saudoso. E,

\footnotetext{
153 Citação dos dois versos de abertura do poema "À ama" (Няне), de Púchkin, escrito em 1826. Púchkin reencontrara-se com sua velha ama Arina Rodiónova em 1824, ano em que é condenado pelo tsar a confinamento na propriedade da família em Mikháilovskoie. Na ocasião, a velha ama conta-lhe diversos contos maravilhosos, os quais o poeta aproveitará mais tarde como material para suas composições.

${ }^{154}$ Sobrenome formado a partir do substantivo mukha, que significa "mosca".

${ }^{155}$ Em russo, o adjetivo feminino "pombinha" pode ser usado como pronome de tratamento, cuja função é denotar carinho.
} 
depois, a ama, de todo modo, está sentada, tricotando, nós a vemos, mas e ele, o que é feito dele? Mas e ele, onde está? "Só, no coração das florestas de abetos Há muito, muito tempo tu esperas por mim" ${ }^{156}$. Ela está só, mas ele nem sequer está! Florestas de abetos eu também conhecia, lá da nossa casa de Tarussa, se você ia pelo vale de salgueiros Patchov ${ }^{157}$ - que mamãe chamava de Escócia em direção ao Ocá, de repente - uma perfeita ilha rubra: os abetos! Com o barulho, com os estalos, com o rubor, com o cheiro, depois da uniformidade e da ondulação dos salgueiros - um perfeito incêndio.

Minha mãe saber fazer barquinhos com a casca, e até à vela, e eu só sei comer a resina e abraçar o pinheiro. Nesses abetos não vive ninguém. Nos abetos, naqueles mesmos abetos, vive a ama de Púchkin. "Estás sob a janela de tua varanda..."158 - tem uma janela muito clara, que ela vive a polir (como nós, na sala, quando esperamos a carruagem do vovô) - para ver se Púchkin vem. E - nada de ele vir. Nunca virá.

Mas o trecho preferido de todo o poema era - "Velas em profunda aflição" 159 , sendo que "velas" não despertava em mim a imagem de vigília, é claro, que eu não entendia, mas justamente de velas, acesas por toda a parte... Imagens de velas - a perder de vista. A ama está sentada aflita e perto dela tem - uma vela. Ou o tempo todo tricotando à luz de velas talvez olhe o relógio. $\mathrm{Ou}$ está tão aflita porque até o relógio parou ou a vela apagou. Pois, para mim, velas eram mais de uma vela - crianças não distinguem palavras homógrafas. De qualquer modo, a incerteza deste velas abria todas as possibilidades relativas a velas, até chegar a imagens já completamente nebulosas: uma vela

\footnotetext{
156 “À ama” (vv. 3 e 4).

${ }^{157}$ Patchov (Почеви): aldeia próxima à datcha "Piessótchnoie", em Tarussa.

158 “À ama” (v. 5).

159 “À ama” (v. 6).
} 
iluminando o relógio da sala, velas e relógios numa gaveta, um candelabro em cima da arca perto do relógio de pêndulo, e tem no quarto de mamãe um cuco, em uma casinha, com o cuco saindo da casinha. O cuco sai à janela como se esperasse por alguém... E a ama, desde a primeira linha é uma pombinha...

Assim, tanto as velas como o relógio, velas iluminando o relógio e todos os relógios à luz de velas eram confirmados no último verso, justamente nas agulhas de tricô, que lembram longas velas e ponteiros de relógios. ${ }^{160}$ E é com essas agulhas nas mãos enrugadas da ama que termina o meu antológico “À ama”.

O autor da antologia deve ter pensado que as crianças de tenra idade não eram capazes de entender nem as saudades, nem os pressentimentos, nem as preocupações, nem o aperto, nem a constância. Eu, naturalmente, além da minha saudade, das duas últimas linhas não teria entendido nada. Não teria entendido - mas teria lembrado ${ }^{161}$. E - lembrei. Assim, até agora, entre mãos enrugadas e portões esquecidos tenho - uma pausa de segundos, como se este final do poema de Púchkin tivesse sido acrescentado - àquele da antologia ${ }^{162}$. Sim, aquilo que a gente sabe desde a infância - a gente sabe durante a vida inteira, mas aquilo que a gente não sabe na infância - não sabe a vida inteira.

O que sei desde criança é que: de todas as mulheres do mundo, a que Púchkin mais amava era a sua ama, que não era qualquer mulher. A partir de “À ama” de Púchkin, eu aprendi para a vida inteira que é possível amar uma mulher velha - porque familiar - mais do que a uma nova - porque é nova e até

\footnotetext{
${ }^{160}$ Neste trecho, Marina Tsvetáieva estabelece um jogo entre "на часах" ( "na tchassakh"), que significa "em sentinela" е “часы” (“tchassi”) que quer dizer "relógio".

${ }^{161} \mathrm{Na}$ edição popular, em vez do verbo "lembrado" (запомнить/zapomnit'), temos o verbo "preencher/completar" (заполнить/zapolnit').

${ }^{162}$ Marina Tsvetáieva refere-se aqui aos seis versos finais do poema "À ama", de Púchkin, os quais, ao que parece, foram excluídos da antologia pelo autor.
} 
porque ela é a mulher amada. Palavras tão ternas, Púchkin não dedicou a nenhuma outra.

Palavras tão ternas dedicadas a uma velha encontram-se apenas num gênio que há pouco nos deixou - Marcel Proust. Púchkin. Proust. Dois monumentos de sentimento filial. ${ }^{163}$

Hoje, ao olhar para trás, vejo que os poemas de Púchkin, e em geral, com raras exceções, os poemas de lírica pura, raros na minha antologia, até os sete anos e aos sete anos eram para mim - uma série de imagens obscuras, - obscuras só por causa das perguntas de mamãe, pois nos versos, como nos sentimentos, somente a pergunta gera a incompreensão, tirando o evento da sua realidade objetiva. Quando mamãe não fazia perguntas - eu entendia perfeitamente, ou seja, nem pensava em entender e simplesmente - via. Mas, por sorte, mamãe nem sempre fazia perguntas e alguns versos permaneciam compreensíveis.

Delibach ${ }^{164}$. "Um tiroteio atrás das colinas - Faz mira no campo deles e no nosso - Na colina diante dos cossacos - Tremula o vermelho delibach"165. O delibach é um diabo. Por isso, o vermelho. Por isso tremula. Bate-se - o cossaco com o diabo. Qual não foi minha surpresa - também

\footnotetext{
${ }^{163} \mathrm{O}$ escritor francês Marcel Proust (1871-1922) em seu romance autobiográfico "Em busca do tempo perdido" escreve palavras de amor à sua "doce e boa" avó.

164 "Delibach" (“Делибаш”), poema de Púchkin escrito em 1829 e composto de quatro estrofes com quatro versos cada.

${ }^{165}$ Primeiro verso de "Delibach".
} 
decepção, quando em Praga, no ano de 1924, primeiro de um estudante russo, depois de outro, depois do terceiro, ouvi que o delibach é a bandeira da Circássia e de forma alguma o próprio circassiano (diabo). “Perdão, mas em Púchkin é 'Tremula o delibach vermelho!' Como um circassiano pode tremular? A Bandeira é que tremula!" - "Pode tremular perfeitamente. Qualquer circassiano com suas roupas e tudo". - "Ora, mas isso já é modernismo. A diferença entre Púchkin e os modernistas é que ele escreve de modo simples, é nisso que está toda a sua genialidade. O que pode tremular? Uma bandeira." - "Eu sempre entendia 'Delibach na ponta da espada e o cossaco decapitado'166 - que ambos haviam liquidado uma ao outro ao mesmo tempo. Era disso que eu gostava". - "Pura fantasia poética! O coitado do Púchkin se reviraria no caixão! 'O delibach na ponta da espada' significa que a bandeira já está na espada e que foi o portabandeira quem decapitou o cossaco" - "Mas pra mim há algo de ofensivo nisso: por que o cossaco foi decapitado e o circassiano está vivo? E como a bandeira pode estar na ponta da espada?? Do meu jeito eu gostava mais". “O seu jeito é o seu jeito, mas foi assim que Púchkin escreveu. Você não vai querer corrigir Púchkin como os bolcheviques"167.

Assim, fiquei com a minha dor, convencida de que o delibach é uma bandeira, e toda aquela cena de mútua destruição fulminante - não passava de invenção da minha cabeça, de repente - em 1936 - no momento em que escrevo, com estes olhos os versos reli - oh, que alegria!

\footnotetext{
${ }^{166}$ Dois versos finais da última estrofe de "Delibach".

${ }^{167}$ Esta frase foi suprimida das edições soviéticas até 1989.
} 
Ei, cossaco, suspende o combate!

Já corre a toda brida o delibach

Ele cortará com o sabre curvo

Dos teus ombros esse crânio robusto! ${ }^{168}$

Então, quer dizer que uma bandeira com um sabre curvo cortará o crânio robusto dos ombros do cossaco?!

Assim, um pobre bárbaro de sete anos tinha compreendido melhor $o$ mais inteligente homem da Rússia ${ }^{169}$ do que os pupilos quatro vezes mais velhos da Universidade de Praga.

Mas um completo enigma era o poema "Montenegrinos? Mas que são? - perguntou Bonaparte"170 - com dois desconhecidos, um em cada linha: Montenegrinos e Bonaparte, os Montenegrinos ainda mais desconhecidos por não serem conhecidos do segundo desconhecido - Bonaparte.

“E Bonaparte - quem é" - não, isso eu não perguntei à mamãe, pois lembrava muito bem do nosso passeio, para mim infeliz, "pelos cepinhos": minha primeira e única tentativa de pergunta durante a infância inteirinha: “Mamãe, quem é Napoleão?" - “Como? Você não sabe quem é Napoleão?” “Não, ninguém me disse”. - “Ora, veja, isso está no ar!”

\footnotetext{
${ }^{168}$ Citação da terceira estrofe de "Delibach".

169 Último verso do poema de Tsvetáieva "Não batas o tambor diante de regimentos incertos" (“Нет, бил барабан перед смутным полком”), de 1931, dedicado a Púchkin.

170 Primeiro verso do poema de Púchkin "Bonaparte e os montenegrinos" ("Бонапарт и черногорцы”), de 1834, que faz parte do ciclo "Canções dos eslavos do norte".
} 
Nunca esquecerei o sentimento da mais profunda e desesperada vergonha: eu não sabia - e aquilo estava no ar! Sendo que, "está no ar", eu, claro, não entendi, mas vi: algo se chama Napoleão e está no ar, o que pouco tempo depois era confirmado pelo poemas "Navio aéreo" e "Ronda noturna"171 da antologia.

Montenegrinos eu, claro, imaginava inteirinho pretos: negros - eu imaginava, Púchkin eu - imaginava, e os montes, nos quais vivia essa tribo má, - inteirinho pretos: pessoas pretas em montes pretos, para cada dente do monte - como as crianças desenham - um minúsculo montenegrino preto e mau (simplesmente, um diabinho). E Bonaparte deveria ser vermelho. E terrível. E sozinho no topo de uma montanha. (Pois eu nem desconfiava que o Bonaparte era - aquele mesmo Napoleão que está no ar, porque mamãe, espantada com a possibilidade de tal pergunta, esqueceu de me responder).

Nem mamãe nem outra pessoa qualquer. 0 que é Napoleão, quem me respondeu foi o próprio Púchkin.

- Ássia! Mússia! Olha só o que eu vou contar pra vocês! - isso era o comprido, veloz Andriucha ${ }^{172}$ com um sorriso meio lupino - veloz e confuso - que trovejando pela escada, irrompeu no nosso quarto. - Agora está lá

\footnotetext{
${ }^{171}$ Trata-se de poemas de M. I. Liérmontov e V. A. Jukóvski, respectivamente.

172 Meio-irmão de Tsvetáieva, filho mais novo do primeiro casamento de Ivan Tzvetáiev. Andriucha é hipocorístico de Andrei.
} 
com a mamãe o doutor Iarkho ${ }^{173}$, e ele disse que ela está tísica e vai morrer, e vai aparecer pra nós, todinha de branco!

A Ássia pôs-se a chorar, o Andriucha pôs-se a pular e eu - eu não consegui fazer nada, porque atrás do Andriucha vinha entrando a mamãe.

- Crianças! O doutor Iarkho esteve agora comigo e disse que estou tísica, e nós todos iremos ao mar. Vocês estão contentes por que vamos à praia?

- Não - já soluçava Ássia - porque o Andriucha disse que você vai morrer e vai aparecer pra nós...

- Mentira! Mentira! Mentira!

- ...todinha de branco. Não é verdade, Mússia, que ele falou?

- Não é verdade, Mússia, que eu não falei? Que foi ela que disse?

- Não importa quem tenha dito, - mas certamente foi você quem disse, Andriucha, porque a Ássia ainda é muito pequena para uma bobagem dessas, você disse uma bobagem. Então quer dizer que eu vou morrer e aparecer? Eu não vou morrer coisa nenhuma e, pelo contrário, nós todos vamos ao mar.

Ao Mar. ${ }^{174}$

\footnotetext{
${ }^{173}$ Médico domiciliar da família Tzvetáiev.

174 “Ао mar" (“К морю”): poema de Púchkin escrito em 1824.
} 
Passei o verão de 1902 inteiro a copiá-lo da antologia num livrinho que eu mesma fiz. Por que num livrinho se tem na antologia? Para levar sempre comigo no bolso, para passear com o Mar no Patchov e nos cepinhos, para que fosse mais-meu, para que eu mesma escrevesse.

Liberdade geral: eu estou sozinha na gaiola do nosso balcão e, encharcada de suor - por causa de julho, do meio-dia, do cimo do sótão, e, sobretudo, no vestido que vovô tinha trazido de Carlsbard dois anos antes de sua morte, guardado até ficar imprestável - encharcada de suor e rasgando por causa do entusiasmo, e um pouco por causa da gola de piquê que descosturava em todas as partes, eu copio numa letra preta, inclinada, redonda, graúda e ainda assim apertada no livrinho que eu mesma fiz - "Ao mar". Este caderninho é fininho para o amor, mas outros não tenho: mamãe não me dá papel para escrever, ela dá para desenhar. O livrinho é uma mão de papel para escrever dobrado oito vezes, cortado onde necessário e costurado no meio, mas só uma vez, por isso, o livrinho fica amassado, desfeito, rasgado e desencadernado - como eu com minha gola de piquê e casaco de cheviote - apesar de todos os esforços para acertá-lo, passando todo o meu tempo livre a sentar-me nele com todo o meu peso e a minha força, e à noite pondo em cima dele a minha pedra preferida - a rajada. Não em cima dele, mas em cima deles, por que no decorrer do verão - torna-se o quê?

Copio e de repente vejo que as linhas, ao final, inclinam-se um pouquinho, ou, copiando, deixo passar uma palavra, ou faço um borrão, ou sujo com a manga o final da página - e acabou: eu não gostarei mais deste 
livrinho, isso não é um livrinho, mas a mais comum das porcarias das crianças. A folha é arrancada, mas um livro com uma folha arrancada é um livro asqueroso, pega-se um novo papel (da Ássia ou do Andriucha) e - com paciência, mas sem nenhum jeito, com uma enorme agulha de bordar (outra não tenho), costura-se um novo livrinho, em que com novo esforço: "Adeus, elemento livre!"175

Os elementos livres são, de certo - os versos ${ }^{176}$, e em nenhuma outra poesia isso é dito com tanta clareza. E por que adeus? Porque o amor é sempre um adeus. Sem adeus não há amor. E “o marco de todos os desejos que trago n'alma"177 - esse marco é algo duro, de pedra, muito resistente, provavelmente, a pedra preferida dele, na qual ele sempre se sentava.

Mas a palavra e o trecho preferidos deste poema:

Em vão dilacerava-se o espírito meu!178

Em vão - isso é para lá. Para onde? Para lá, para onde também quero ir. Para a outra margem do Ocá, para a qual nunca pude ir, porque entre nós havia o Ocá, ainda em La Chaux de Fonds, na infância da tia ${ }^{179}$, em que à noite caminha [ronda] um guarda com uma lousa e canta: “Gué, bon gué! Il

\footnotetext{
${ }^{175}$ Primeiro verso de "Ao mar”, de Púchkin.

176 Jogo de palavras entre "стихии" (stikhii - plural de “стихия"/stikhía), que significa "elemento", е “стихи" (stikhi), usada tanto para designar "poema" quanto "verso".

177 "Ao mar" (III, v. 1).

178 “Ao mar" (VII, v. 2)

${ }^{179}$ La Chaux de Fonds é uma aldeia suíça. A tia a que se faz referência é a ex-governanta da mãe de Tsvetáieva, proveniente da Suíça e com quem o avô da poeta se casara na velhice.
} 
frappé dix heures!"180 - e todos apagam as luzes, mas se não apagam, então vem o médico ou metem na cadeia; em vão - isso numa outra família, onde sou sozinha, sem Ássia, e a filha mais amada, com outra mãe e com outro nome - quem sabe Kátia, e quem sabe, Rogneda, e quem sabe, o filho Aleksandr ${ }^{181}$.

Tu me esperavas, tu chamavas. Eu não ia.

Em vão dilacerava-se o espírito meu

Escravo de intensa paixão eu me esvaia

Petrificado à beira-mar ficava eu. ${ }^{182}$

Em vão - isso é para lá e a intensa paixão, certamente, é para com o mar. Como se justamente por conta de um tal desejo de ir para lá, Púchkin ficava à beira-mar.

Então, por que é que ele não tinha ido? Ora, porque escravo de uma intensa paixão, de tanto querer - ele fica paralisado! (Isso eu tirava da minha própria experiência de criança, eu queria alguma coisa e ficava paralisada.) E com todo o peso do destino e da renúncia:

Petrificado à beira-mar ficava eu.

\footnotetext{
${ }^{180}$ Em francês, no original.

${ }_{181}$ A mãe de Marina Tsvetáieva sonhava em ter um filho, ao qual daria o nome de Aleksandr. 182 "Ao mar", estrofe VII.
} 
(Meu Deus! Como a pessoa perde ao adquirir um sexo, quando em vão, para lá, aquilo, lá passam a ter um nome, quando o azul da angústia e do rio formam um rosto, com nariz, com olhos, e na infância até de pincenê e bigode... E como nos enganamos cruelmente, chamando isto - de aquilo, e como - naquele tempo não nos enganávamos!)

Mas eis um nome - sem patronímico, um nome ao qual na lápide tumular, os últimos fiéis, com o instinto infalível de suas pequenas forças, recusaram-se a acrescentar o sobrenome (essa pessoa tinha dois nomes, mas não tinha sobrenome) - e a lápide permaneceu vazia.

Rochedo solitário, túmulo de glórias.

Ali, mergulhadas em sono profundo e vão

De grandeza todas as antigas memórias:

Era ali que se extinguia Napoleão. ${ }^{183}$

Ah, se eu tivesse lido esses versos antes, não perguntaria: "Mamãe, o que é Napoleão?" Napoleão é aquele que morreu entre martírios, aquele a quem martirizaram. Será que é pouco - para amar a vida inteira?

E depois dele, qual temporal barulhento

Outro gênio partiu desta para melhor

183 “Ao mar”, estrofe IX. 
Outro soberano do nosso pensamento. ${ }^{184}$

Vejo uma estrelinha e abaixo uma nota de rodapé: Byron.

Mas, já não vejo a estrelinha, vejo: acima de não sei o que fica - o mar, com a cabeça radiosa, com o corpo de nuvens, o gênio está voando. Ele se chama Byron.

Isso era o auge da inspiração. Com “Então, adeus, mar...” as lágrimas rolam. “Então, adeus, mar! Eu não te esquecerei..."185 - é o que ele promete - ao mar, como eu - à minha bétula, à minha aveleira, ao meu pinheiro, quando vou embora de Tarussa. Mas o mar, talvez, não acredite e pense que ele - vai esquecer, então ele promete de novo: "E assim, para sempre um ouvinte serei - do teu bramido cada vez que a noite cai..."186 (Não esquecerei - serei -).

Através de florestas, de desertos ermos

Hei de levar sempre, carregado de ti

Estes teus rochedos e tuas enseadas

O brilho, a sombra, o murmúrios das ondas. ${ }^{187}$

\footnotetext{
184 “Ao mar" (X, vv. 3-5).

185 "Ao mar" (XIV, v. 1).

186 “Ao mar" (XIV, vv. 3 e 4).

${ }^{187}$ Última estrofe de "Ao mar".
} 
É esta - a imagem: Púchkin que leva, que carrega, na cabeça - o mar inteirinho, que também está dentro dele (carregado de ti), assim, também dentro dele tudo é azul - como se ele todo, até o céu, estivesse dentro de um enorme ovo de cristal deitado, que também está dentro dele (Uma Abóbada Marinha). Assim como aquele Púchkin do bulevar Tvier que sustenta nos ombros todo o céu, este também levará consigo - todo o mar através do deserto e lá o derramará - e o mar se fará.

Através de florestas, de desertos ermos

Hei de levar sempre, carregado de ti

Estes teus rochedos e tuas enseadas

O brilho, a sombra, o murmúrios das ondas.

Quando eu dizia ondas, as lágrimas escorriam, todas as vezes, elas escorriam, e também por isso, às vezes, eu tinha que começar uma nova folha.

Desse meu amor, justamente por sua evidência, ninguém sabia, e quando em novembro de 1902, a mamãe ao entrar no nosso quarto disse: 
ao mar - ela não suspeitava que estava pronunciando uma palavra mágica, que estava pronunciando Ao mar, ou seja, estava fazendo uma promessa que não pode cumprir.

Desde então, eu ia $A o$ Mar, todo aquele mês antes da partida, já de férias, interminável e sem ter o que fazer eu, sozinha, incessantemente, ia Ao Mar.

Até hoje ouço o meu insistente e maçante, a todos e a cada um deles: "Vamos sonhar!". Sob o delírio, a tosse e o sufoco de mamãe, sob o rebôo e o ranger da casa sacudida pela partida - o obstinado - sonâmbulo e imperioso, mas também suplicante: "Vamos sonhar!" Pois antes que você entenda que sonho e sozinho é uma coisa - só, que o sonho é a prova cabal da solidão, e fonte dela, e a única compensação, assim como a solidão é a sua - lei draconiana e o seu único campo de ação, até que com isso você se resigne - a vida vai passando, mas eu ainda era uma menina muito pequena.

- Ássia, vamos sonhar! Vamos sonhar um pouquinho! Só um pouquinho!

- Nós já sonhamos hoje, eu estou cansada. Quero desenhar.

- Ássia! Eu dou pra você o ovinho, aquele do Serguei-Semiônitch ${ }^{188}$.

- Ele está rachado.

- Está rachado por dentro, mas por fora ele está inteiro.

\footnotetext{
${ }^{188}$ Trata-se de um brinquedo de madeira em forma de ovo com um boneco pintado, ao qual as irmãs deram o nome de Serguei-Semiônitch.
} 
- Então vamos. Mas vamos sonhar bem rápido, porque eu quero desenhar.

O ovinho foi dado, mas logo em seguida tomado, porque Ássia, além das pedrinhas e das conchinhas, não tinha nada guardado para sonhar com o mar. Às vezes, eu batia nela por causa dessas conchinhas.

Com Ássia, Ao Mar despedaçava-se em cascalho, com Valéria, minha irmã mais velha, que conhecera o mar na Criméia, transformava-se em pantufas tártaras - e em datcha - em glicínias - em rochedo Dieva e em rochedo Monakh, transformava-se em tudo o que se desejar - além de mim mesma e do meu mar, depois daqueles "vamos sonhar" não me restava nada, além do meu saudoso desconhecimento.

O que então eu queria deles - de Ássia, de Valéria, da governanta Maria Guénrikhovna, da camareira Aricha - que também iam?

Talvez - o monumento de Púchkin no bulevar Tvier e embaixo dele o murmúrio das ondas? Mas não - não era nada disso. Não havia nada de visual e material no meu Ao Mar, havia os barulhos daquela concha australiana rosa apertada contra a orelha, e imagens vagas - do tal Byron e do tal Napoleão, cujos rostos eu nem conhecia, e o que é importante, - os sons das palavras, e - o que é mais importante ainda - a saudade: da vocação e da despedida puchkinianas.

E se Ássia, por ter aprendido com alguém, dizia "pedrinhas, conchinhas", se Valéria, fruto de sua experiência na Criméia, nomeava 
glicínias e Simeiz ${ }^{189}$, eu, por mais que desejasse, não podia dizer - não podia nomear - nada.

Mas justamente no último instante chegou a ajuda: a primeira e a única garantia da existência do mar: um postal azul-marinho de Nádia Ilováiskaia daquela mesma Nervi190 para onde nós - íamos. Tudo - azulmarinho: lugares e postais de um azul assim, eu nunca tinha visto, e nem sabia que existiam.

Os pinheiros azul-escuros - a lua azul-clara - as nuvens azul-escuras - saindo da lua qual uma coluna, uma luz azul-clara - e dos dois lados dessa coluna - um azul tão escuro que não se podia ver nada - o mar. Minúsculo, imenso, todo negro, completamente invisível - o mar. E na margem, nas nuvens, nas quais um outro mestre de nossas vidas partiu desta para melhor, barrando de leve o olho da lua - à tinta lilás, em letras cheias de volteios como os cachos de seus próprios cabelos: "Venha o mais rápido. Aqui é maravilhoso".

Desse postal eu tomei posse. Esse postal, logo em seguida, eu roubei de Valéria. Roubei e enterrei por dois dias na minha escrivaninha preta, um pouquinho como as moças que atiram ao poço o rebento do amor - com

\footnotetext{
${ }^{189}$ Balneário situado na Criméia.

${ }^{190}$ Em caracteres latinos no original.
} 
todo o amor! Sempre, furtivamente, eu, segurando com a testa a tampa da escrivaninha, olhava esse postal, literalmente queimava e devorava com os olhos. Com esse postal, eu vivia - como aquela moça com o amado - secreta, perigosa, proibida, venturosamente.

No fundo do caixão e da gruta da escrivaninha preta jazia o meu tesouro. No fundo do caixão e da gruta da escrivaninha preta jazia - o mar. O meu mar, completamente negro por causa do negrume da escrivaninha e do meu ato. Pois eu o tinha roubado - para que outros não vissem, para que os outros que tinham visto - esquecessem. Para que apenas eu visse. Para que fosse -meu.

Assim, com o rosa vivo e profundo da concha australiana na orelha, com o azul-escuro do postal diante dos olhos, eu ia levando o mais longo, o mais vazio, o mais completo mês da minha vida, a minha grande véspera, depois da qual nunca chegou o dia.

- Ássia! Mússia! Olhem! O mar!

- Onde? Onde?

- Está lá! 
Lá: um pedaço de floresta pelada, toda de galho e cordas, e em algum lugar lá embaixo - uma água clara, plana, sem graça, uma aguinha, tão pouca quanto aquela no quadro Aparição de Cristo ao povo.

Isto é o mar? Eu e Ássia trocamos um olhar com um muxoxo de sincero desprezo.

Mas - mamãe explicou e nós acreditamos: isto é o golfo de Gênova, e o golfo de Gênova é sempre assim. $O$ mar fica - pra amanhã.

Mas amanhã, e muitos, muitos amanhãs depois, não havia mar, havia a escarpa de um hotel genovês, um ladeira estreita, com casas tão aglomeradas que se houvesse um mar - ele recuaria. Os passeios com papai no porto não contavam. Para aquele "mar" eu nem olhava, pois sabia que aquilo não passava - de um golfo.

Em suma, eu ainda estava indo $A o$ Mar, e quanto mais perto eu chegava - menos eu acreditava nisso, e no meu último dia em Gênova cheguei a desacreditar completamente e até me alegrei um pouco, quando papai, alegre porque o mercúrio do termômetro de mamãe cedeu um pouco, disse-nos - pela manhã: "Pois bem, crianças! Hoje à tarde vocês vão ver o mar!" Mas o mar só recuava, pois quando nós, finalmente, depois de todos aqueles hotéis, plataformas, vagões, Modans ${ }^{191}$ e Victores-Emanuéis ${ }^{192}$, "hoje a tarde" com todos os nossos baús e trouxas, invadimos a "Pension Russe" de Nervi - era noite e o gás nunca antes visto ardia e piscava com

\footnotetext{
${ }^{191}$ Modan é uma pequena cidade francesa conhecida por abrigar um túnel que liga França e Itália.

${ }^{192}$ Hotéis italianos que levam o nome de Victor Emanuel II (1820-1878), rei da Itália.
} 
seu olho terrível, e mamãe estava de novo ardendo em febre, e eu preferia morrer do que me atrever a pedir para ir "ao mar".

Mas ainda que mamãe estivesse completamente saudável e tão de bem comigo como as outras mães com as outras meninas, mesmo assim, eu não pediria para ir.

O mar estava ali, e eu estava ali, e entre nós - a noite, todo o negrume da noite e do quarto estranho, e este negrume inevitavelmente vai passar e ambos estaremos ali.

0 mar estava ali, e eu estava ali, e entre nós - todo o prazer desse adiamento.

Oh, como eu passei a noite inteirinha - indo para o mar! (Para onde mais senão para lá - quando?) Mas não apenas eu ia para ele e ele vinha para mim nesta noite - através de todo o negrume da noite - ele vinha: para mim ali sozinha - todinho para mim.

0 mar esteve ali, e amanhã vou vê-lo. Ali e amanhã. Tamanha plenitude da posse e tamanha tranqüilidade da posse, eu nunca mais senti. Esse mar era a minha medida.

O mar está ali, mas não sei onde, e como não o vejo - então ele está mesmo em toda parte, não há lugar onde ele não esteja, eu simplesmente estou nele, como aquele postal no caixão preto da escrivaninha.

Essa foi a maior véspera de minha vida.

O mar está ali - e não está. 


\begin{abstract}
Pela manhã, a caminho do mar, a Valéria:
- Sente como cheira? Está cheirando daqui!
\end{abstract}

Não há como não sentir! Está cheirando daqui, e está cheirando por toda parte, mas... é que justamente não reconheço: o elemento livre não cheirava assim, e o postal azul não cheirava assim.

Ponho-me de sobreaviso.

Mar. Olho de olhos bem abertos. (Assim eu, passados dezoito anos, de olhos bem abertos, pela primeira vez, olhei Blok ${ }^{193}$.).

Um rochedo negro com uma estaca de ferro apontando para o alto.

- Esse rochedo se chama rã - apressa-se a apresentá-lo o filho ruivo do proprietário. - Essa é a nossa rã.

De mim até a rã há - um tantinho: um tantinho de água muito limpa, muito clara: no fundo, pedrinhas e vidrinhos (como os de Ássia).

\footnotetext{
193 O fato se passou em 9 de maio de 1920, quando Blok esteve em Moscou para um sarau
} literário no Museu Politécnico. 
- E isto é uma gruta, - esclarece Volódia, olhando para baixo, - a gruta também é nossa, aqui tudo é nosso, se você quiser, podemos escalar! Só que você vai afundar!

Escalo e afundo, nos minhas pesadas botinas russas, com o meu pesado vestido marrom de feltro, em seguida, caio na água (na água, e não no mar), e o ruivo Volódia me puxa e eu tiro a água das botinas, e depois sento perto delas e, vestida, fico secando - para que mamãe não fique sabendo.

Ássia e Volódia, secos e cheios de desdém escalam a "plataforma", a parede lisa do rochedo de ardósia, e de lá, sob os pinheiros, atiram lascas e pinhões.

Fico ali secando e olho: vejo agora que atrás do rochedo Rã há mais água, muita, quanto mais longe, mais pálida, e que vai acabar numa linha reta branca e brilhante - do mesmo prateado que os pontinhos nas marolas. Eu estou completamente salgada - e as minhas botinas também.

O mar é azul - e salgado.

E, de repente, dando-lhe as costas, escrevo com uma lasca de rocha no rochedo.

Adeus, elemento livre! 
Os versos são longos, e eu comecei do alto, o quanto a mão alcançava, mas os versos, por experiência própria eu sei, são tão longos que nenhum rochedo basta, e ali perto não há outro que seja tão liso, mas apesar disso, as letras aperto e aperto, espremo e espremo, e as últimas não passam de conchinhas, e sei que agora virá a onda e não deixará que eu termine, então o desejo não se realizará - qual desejo? ah, Ao Mar! - mas, quer dizer que já não há nenhum desejo? Mas, mesmo assim, até sem desejo! eu preciso acabar de escrever antes da onda, acabar tudo antes da onda, mas a onda já vem vindo, e eu bem que ainda tenho tempo de assinar:

Aleksandr Serguéievitch Púchkin-

E daí tudo é lavado, como que lambido por uma língua, e de novo estou toda molhada, e de novo a ardósia lisa, já preta agora, como aquele granito...

Desde aquele primeiro encontro amar o mar, eu nunca amei. Foi pouco a pouco que eu, como todos, aprendi a usá-lo e a brincar com ele: pegar e atirar-lhe pedrinhas - assim como um jovem que tendo sonhado com o grande amor, pouco a pouco, aprende a aproveitar a ocasião. 
Hoje, mais de trinta e poucos anos depois, eu vejo: meu Ao mar era o peito de Púchkin, pois eu estava indo para dentro do peito de Púchkin, com Napoleão, com Byron, com o barulho, e com a água espirrando, e com o murmúrio das ondas da alma do poeta, e naturalmente nem no mar Mediterrâneo com o rochedo Ranocchia, e depois nem no Negro, e nem depois ainda no Atlântico, esse peito - eu reconheci.

No peito de Púchkin - naquele postal azul que misturava todo o azul do mundo e do mar.

(Mas o mais certo de tudo - naquela concha que murmurava no ouvido).

Ao mar era: o mar + o amor que Púchkin lhe tinha, o mar + o poeta, não! - o poeta + o mar, dois elementos, sobre os quais Boris Pasternak de modo inesquecível escreveu:

O elemento do elemento livre

Com o elemento livre do verso, -194

omitindo ou deixando subentendido o terceiro e único: o elemento lírico.

\footnotetext{
${ }^{194}$ Citação de versos do poema de Boris Pasternak. "Tema e variações. Variante 1. Original" (“Тема и варианциями. Варианция I. Оригинальная."), de 1918, inspirado em "Ao mar”, de Púchkin.
} 
Mas Ao mar era também o amor do mar a Púchkin: o mar - amigo, o mar - que chama e espera, o mar que teme que Púchkin - o esqueça, e para o qual, como para um ser vivo, Púchkin promete e torna a prometer. 0 mar é correspondido, aquele único caso de correspondência - cheia até a borda e transbordando além do mar, e não vazia, como no amor feliz.

Este mar - o meu mar - o mar de Ao mar, o meu e o de Púchkin, só podia existir numa folha de papel - e no íntimo.

E tem mais: o mar de Púchkin era - o mar do adeus. De modo que- os mares e as pessoas - não se encontram assim. Mas - dizem adeus. Como é que eu podia, saudando o mar nesse primeiro encontro, sentir aquilo que sentia Púchkin lhe dizendo adeus para sempre. Pois era essa a última vez que Púchkin o via.

O meu mar - do elemento livre de Púchkin - era o mar da última vez, do último olhar.

Será que é porque eu, bem criança ainda, escrevi tantas vezes com a minha própria mão: “Adeus, elemento livre!" - ou sem qualquer por que todas as coisas da minha vida, eu amei e desamei na despedida, e não no encontro, no rompimento, e não no enlace, não na vida - mas para a morte.

E, já totalmente num outro sentido, meu encontro com o mar resultou, justamente, a despedida dele, uma dupla despedida: do mar de elementos livres, que não se abria diante dos meus olhos e que eu, apenas dando as costas ao mar verdadeiro, reconstruí - branco sobre cinza, ardósia 
sobre ardósia - e a despedida daquele mar verdadeiro, que se abria diante dos meus olhos e que eu, por causa daquele primeiro, já não podia amar.

E - digo mais: a ignorância dos meus tempos de criança que confundia elemento livre com versos era uma - intuição: o "elemento livre" era os versos, mas não o mar, os versos, ou seja, o único elemento ao qual jamais se diz adeus. 


\section{Bibliografia Geral}

\section{Obras de Marina Tsvetáieva:}

ЦВЕТАЕВА, М. И. В завтра речь держу.. (автобиографическая проза: 1925-1937). Издание подготовили А. А. Саякянц и Л. А. Мнухин. Москва: Варгус, 2005.

. Собрание сочинений: В 7 m. Сост., подгот. текста и

коммент. А. А. Саакянц и Л. А. Мнухина. М., 1994-1995.

. Записнсые книжки и дневниковая проза. Москва:

Захаров, 2003.

ЦВЕТАЕВА, М., ПАСТЕРНАК, Б. Дуии начинают видеть (Писма 19221936 годов). Издание подготовили Е. Б. Коркина и И. Д. Шевеленко. Москва: Варгус, 2004.

ЦВЕТАЕВА, М., ГРОНСКИЙ, Н. Несколько ударов сердца (Писма 19281933 годов). Издание подготовили Ю. И. Бродовская и Е. Б. Коркина. Москва: Варгус, 2004.

TSVETÁÏEVA, M., PASTERNAK, B. RILKE, R. M. Correspondance à trois. Eté 1926. Textes russe traduits por Lily Denis. Textes allemands traduits par Philippe Faccottet. Le poèmes de Marina Tsvetáïeva son traduits par Ève Malleret. Coordination du texte français: Lily Denis. Paris, Gallimard, 2005.

TSVETÁIEVA, Marina. Indícios Flutuantes. Prefácio, seleção e tradução de poemas Aurora Fornoni Bernardini. São Paulo: Martins, 2006. 
. Vivendo sob o fogo: confissões. Seleção organização e prefácio: Tzvetan Todorov. Tradução: Aurora Fornoni Bernardini. São Paulo: Martins, 2008.

TSVETAEVA, Marina. Índices Terrestres. Traduit du russe et présenté par Véronique Lossky. Paris : Clémence Hiver Éditeur, 1987.

- Les Flagellantes. Traduit du russe et présenté par Denise Uaccoz-Neugnot. Clémence hiver éditeur.

- Indícios Terrestres. Tradução Nina Guerra e Filipe Guerra. Lisboa: Relógio d’Água, 1995.

- O Diabo. Tradução Nina Guerra e Filipe Guerra. Lisboa: Relógio d’Água, 1994.

. Depois da Rússia. Tradução (1922-1925). Tradução Nina Guerra e Filipe Guerra. Lisboa: Relógio d'Água, 2001.

. Vivre dans le feu. Confessions. Présenté par Tzvetan Todorov. Traduit du russe par Nadine Dubourvieux. Paris: Robert Laffonto, 2005. 


\section{Obras sobre Marina Tsvetáieva}

BELKINA, Maria. Le destin tragique de Marina Tsvetaeva. Traduit du russe par Wladimir Berelowitch. Poèmes traduit par Lydia Epschtein-Diky. Éditions Albin Michel S.A. : Paris, 1992.

BERNARDINI, Aurora F. Indícios flutuantes em Marina Tzvetáieva. Tese de Livre-docência.

KARLINSKY, S. Marina Cvetaeva - her life and art. Berkeley e Los Angeles: University of California Press, 1966.

КУДРОВА, И. В. Путь Комет в 3 m. Санкт-Петербурк: Крига, 2007.

LOSSKY, Véronique. "Preface”. In: TSVETAEVA, Marina. Indices Terrestres. Traduit du russe et présenté par Véronique Lossky. Paris : Clémence Hiver Éditeur, 1987.

МНУХИН, Л. А. Марина Цветаева в критике современиков в 2-х ч. Москва: Аграф, 2003.

YACCOZ-NEUGNOT, Denise. "Posface". In: TSVETAEVA, Marina. Les Flagellantes. Traduit du russe et présenté par Denise Uaccoz-Neugnot. Clémence hiver éditeur.

СААКЯНЦ, Анна. “Проза Марины Цветаевой”. In: Спасибо Вам! . Только ли о Марине Цветаевой. Москва: Аграф, 2002.

ЦВЕТАЕВА, Анастасия. Маринин Дом. Москва: Дом-музей Марины Цветаевой, 2006.

ШВЕЙЦЕР, Викитория. Быт и бытие Марины Цветаевой. Москва: Молодая Гвардия, 2007. 


\section{Obras escolhidas de Púchkin}

Пушкин, А. С. "Цыганы”; “Бесы”; “Зимная Дорого”; "Exegi monumentum (“Я памятник себе воздвиг нерукотворный...”)”; “Вурдалак”; “К няне”; “К морю”; “Евгени Онегин”; “Полтава Песня”. In: Сочинения. Редакция текста и комментарии М. А. Цявловского и С. М. Петрова. Москва: Государственное Издате льство Художесвенной Литературы: 1949.

\section{Bibliografia geral}

ADORNO, Theodor W. "Sinais de pontuação". In: Notas de Literatura I. Tradução e apresentação Jorge M. B. de Almeida. São Paulo: Duas Cidades; Ed. $34,2003$.

ANDRADE, Homero Freitas de. "A vida do senhor Bulgákov". In: O diabo solto em Moscou. São Paulo: Editora da Universidade de São Paulo, 2002. . "Cronologia da vida e da obra de A. S. Púchkin”. Dossiê Púchkin" (org. Homero Freitas de Andrade). In: Cadernos de Literatura e Cultura Russa. Curso de Russo. DLO/FFLCH/USP. São Paulo: Ateliê Editorial, 2004.

• "A literatura que Stálin proibiu". In:

Revista de estudos orientais I. DLO/FFLCH/USP. São Paulo: Humanitas Publicações, 1997.

AUERBACH, Erich. Mimesis. A representação da realidade na literatura ocidental. São Paulo: Ed. Perspectiva, 1971. 
BELOV-ANDRÉEV, Yuri. Revista de literatura sovietica (para ell50 aniversario de la muerte de Pushkin). Moscou: Unión de Escritores de la URSS, 1987.

BERNARDINI, Aurora. "Púchkin e o começo da literatura russa". "Dossiê Púchkin" (org. Homero Freitas de Andrade). In: Cadernos de Literatura e Cultura Russa. Curso de Russo. DLO/FFLCH/USP. São Paulo: Ateliê Editorial, 2004

BRONTË, Charlotte. Jane Eyre. Tradução de Lenita Esteves e Almiro Piseta. São Paulo, Paz e Terra, 1996.

CAMPOS, Haroldo. "Púchkin: a poesia da gramática". Dossiê Púchkin" (org. Homero Freitas de Andrade). In: Cadernos de Literatura e Cultura Russa. Curso de Russo. DLO/FFLCH/USP. São Paulo: Ateliê Editorial, 2004.

EHRENBURG, Ilya. Memórias. Tradução Boris Schnaiderman. Rio de Janeiro: Civilização Brasileira, 1964.

FIGES, Orlando. A tragédia de um povo. A Revolução Russa 1891 - 1924. Tradução Valéria Rodrigues. Rio de Janeiro: Record, 1999.

JAKOBSON, Roman. Diálogos. Tradução do texto francês Elisa Angotti Kossovitch. São Paulo: Cultrix, 1985.

. "Lingüística e Poética". In : Língüistica e Comunicação. Tradução Isidoro Blikstein e José Paulo Paes. São Paulo: Cultrix, 1969.

Russie folie poésie. Paris: Editions du Seul, 1986. 
- A geração que esbanjou seus poetas. Tradução e posfácio Sonia Regina Martins Gonçalves. São Paulo: Cosacnaify, 2006.

. "Notas à margem da lírica de Púchkin". Tradução e notas Homero Freitas de Andrade. "Dossiê Púchkin" (org. Homero Freitas de Andrade). In: Cadernos de Literatura e Cultura Russa. Curso de Russo. DLO/FFLCH/USP. São Paulo: Ateliê Editorial, 2004.

. “Como foi feita uma quadra de Púchkin". Tradução e notas Homero Freitas de Andrade. "Dossiê Púchkin” (org. Homero Freitas de Andrade). In: Cadernos de Literatura e Cultura Russa. Curso de Russo. DLO/FFLCH/USP. São Paulo: Ateliê Editorial, 2004.

. "Notas à margem de Evguéni Oniéguin". Tradução

Homero Freitas de Andrade e Hugo Camargo Rocha; notas de Homero Freitas de Andrade. "Dossiê Púchkin" (org. Homero Freitas de Andrade). In: Cadernos de Literatura e Cultura Russa. Curso de Russo. DLO/FFLCH/USP. São Paulo: Ateliê Editorial, 2004.

MAIAKÓVSKI, Vladímir. Poemas. Apresentação: Boris Schnaiderman. Tradução: Boris Schnaiderman, Augusto de Campos e Haroldo de Campos. São Paulo: Ed. Perspectiva, 1997.

MONTEFIORE, Simon Sebag. Stálin : a corte do czar vermelho. Tradução: Pedro Maia Soares. São Paulo: Companhia das Letras, 2006.

NAZARIO, Helena. "Humor e irreverência na prosa de Púchkin”. Dossiê Púchkin" (org. Homero Freitas de Andrade). In: Cadernos de Literatura e Cultura Russa. Curso de Russo. DLO/FFLCH/USP. São Paulo: Ateliê Editorial, 2004. 
LO GATTO, Ettore. La literatura ruso-sovietica. Traducción Oreste Frattoni. Buenos Aires: Editorial Losada, 1973.

LOTMAN, Iuri. "A Dama de Espadas e o tema das cartas e do carteado na literatura russa do começo do século XIX”. Tradução e notas Helena Nazario. Dossiê Púchkin" (org. Homero Freitas de Andrade). In: Cadernos de Literatura e Cultura Russa. Curso de Russo. DLO/FFLCH/USP. São Paulo: Ateliê Editorial, 2004.

NAZARIO, H. S. A filha do capitão e o jogo das epígrafes. São Paulo: Editora Perspectiva, 1980.

PÚCHKIN, Aleksandr. "Do Evguiéni Oniéguin”. Tradução Haroldo de Campos e Boris Schnaiderman. "Dossiê Púchkin" (org. Homero Freitas de Andrade). In: Cadernos de Literatura e Cultura Russa. Curso de Russo. DLO/FFLCH/USP. São Paulo: Ateliê Editorial, 2004. • "Romance em cartas". Tradução e notas Homero Freitas de Andrade. "Dossiê Púchkin" (org. Homero Freitas de Andrade). In: Cadernos de Literatura e Cultura Russa. Curso de Russo. DLO/FFLCH/USP. São Paulo: Ateliê Editorial, 2004.

. "Sobre a poesia clássica e romântica". Tradução e notas Homero Freitas de Andrade. "Dossiê Púchkin" (org. Homero Freitas de Andrade). In: Cadernos de Literatura e Cultura Russa. Curso de Russo. DLO/FFLCH/USP. São Paulo: Ateliê Editorial, 2004. . "Esboços de um prefácio a Boris Godunov". Tradução e notas Homero Freitas de Andrade. "Dossiê Púchkin" (org. Homero Freitas de 
Andrade). In: Cadernos de Literatura e Cultura Russa. Curso de Russo. DLO/FFLCH/USP. São Paulo: Ateliê Editorial, 2004.

PÚCHKIN, A. S. A dama de espadas: prosa poemas. Tradução de Boris Schnaiderman e Nelson Ascher. São Paulo: Ed. 34, 1999.

SCHAIDERMAN, Boris. Os escombros e o mito - a cultura e o fim da União Soviética. São Paulo: Companhia das Letras, 1997. . A Poética de Maiakóvski através de sua prosa. São

Paulo: Ed. Perspectiva, 1971.

VERNANT, Jean-Pierre. Mito e pensamento entre os gregos: estudos de psicologia histórica. Tradução de Haiganuch Sarian. São Paulo, Difusão Européia do Livro. Ed. Da Universidade de São Paulo, 1973.

VÁRIOS AUTORES. Poesia Russa Moderna. Tradução de Augusto de Campos, Haroldo de Campos e Boris Schnaiderman $-6^{\text {a }}$ ed. rev. e ampl. - São Paulo: Perspectiva, 2001.

VOLKOGONOV, Dmitri Antonovitch. Stálin: triunfo e tragédia. Tradução Joubert de Oliveira Brízida. Rio de Janeiro: Nova Fronteira, 2004. 
Apêndice 


\section{Índice de nomes e referências}

ANTHÉS HEECKEREN, barão Georges-Charles d' (1812-1887): cidadão francês, filho adotivo do embaixador da Holanda na Rússia, barão Heecheren, entrou para o exército russo em 1833. Apaixona-se por Natália Gontcharova, esposa de Púchkin, e passa a cortejá-la. Isso provoca ciúmes no poeta, que desafia d'Anthés para um duelo. Neste duelo, em 1937, d'Anthés acerta um tiro fatal no poeta. Por esse motivo é expulso do exército e da Rússia. Retorna, com o pai adotivo e a esposa, Ekaterina Gontcharova, irmã de Natália, à França, onde entra para a política e logo é nomeado senador de França.

BLOK, Aleksandr Aleksandrovitch (1880-1921): poeta, filósofo, ensaísta e dramaturgo. Considerado um dos mais importantes poetas do Simbolismo russo, também aventurou-se no campo cubo-futurista. Com a saúde frágil, morre de inanição em 1921.

FALCONET, Étienne-Maurice (1716-1791): escultor francês. Sua obra mais famosa é O cavaleiro de bronze, estátua eqüestre de Pedro, o Grande, situada em São Petersburgo (Rússia).

GONTCHAROVA, Natália Nicoláievna, depois N. N. Púchkina (1812-1863): esposa de Aleksandr Púchkin. 
GONTCHAROVA, Natália Sergueiévna (1881-1962): renomada pintora da vanguarda russa. Pintou obras expressionistas, cubistas e futuristas, mas encontrou maior expressividade no primitivismo, escola que ao lado do marido Mikhail Larionov ajudou a criar e desenvolver.

HANNIBAL, Abraham (Ibrahim) Petróvitch (1669-1781): bisavô materno de Púchkin, engenheiro militar e general na época de Pedro, o Grande.

HANNIBAL, Óssip Abrámovtich (1744-1806): avô materno de Púchkin.

HETMAN: título atribuído ao segundo posto do alto comando militar, usado pela Polônia e pelo Grão-Ducado da Lituânia entre os séculos XV e XVI, e por ucranianos e cossacos do século XVI ao XX.

ILOVÁISKAIA, Nadiejda (1882-1905): filha de D. I. Ilováisk e A. A. Kovráiskaia, uma das amigas mais próximas da mãe de Tsvetáieva.

JUKÓVSKI, Vassíli Andrieiévitch (1783-1852): poeta russo e respeitado tradutor, destaca-se por seus poemas românticos inspirados na escola francesa.

KOTCHUBIEI, Vassíli Leontievitch (1640-1708): general do exército tsarista russo na época da Grande Guerra do Norte.

KRONSTADT, João de ou SERGIEV, Ioann Ilitch (1829-1909): padre ortodoxo e conhecido pensador religioso. Hoje é canonizado. 
MEIN, Aleksandr Danílovitch (1836- 1899): avô materno de Tsvetáieva. Foi jornalista e colaborador de diversos jornais moscovitas.

MEIN, Maria Aleksandrovna (1869-1906): mãe de Marina Tsvetáieva. Depois de casada, passa a se chamar M. A. Tsvetáieva.

MÍNIN E POJÁRSKI: foram figuras fundamentais na batalha contra a invasão polonesa de Moscou (1605-1618), pois foi a ação da dupla que, depois de concentrar suas tropas em Níjni-Novgórod, partiu para Moscou e libertou a então capital da Rússia. O feito tem como conseqüência a coroação do tsar Mikhail, dando início à dinastia Romanov no ano de 1613.

NAÚMOV, A. A. (1840-1895): pintor russo, naturalista, suas telas mais famosas são Bielínsky diante da morte (Белинский перед смертью), de 1882, е $O$ duelo de Púchkin com D’Anthès (Дуэл Пушкина с Дантэсом), data de 1884 .

NICOLAU I (1706-1855): imperador da Rússia entre 1825 e 1855. Seu reinado foi um dos mais opressores do século XIX: deu cabo à Revolta Dezembrista de 1825, perseguiu e exilou diversos intelectuais e artistas, entre eles, Púchkin.

NICOLAU II (1868-1918): o último tsar da Rússia. Governou de 1894, quando da morte de seu pai Alexandr III, até 1917, ano em que foi derrubado pela Revolução Russa. 
OPEKÚCHIN, A. M. (1838-1923): escultor russo, cuja obra mais famosa é $O$ monumento de Púchkin, situado em Moscou (Rússia).

PASTERNAK, Boris Leonidovitch (1890-1960): poeta, tradutor e prosador russo bastante conhecido no Ocidente. Ligado a princípio aos grupos simbolista e acmeísta, participou mais tarde do movimento futurista como um dos criadores do grupo Centrífuga. Considerado um dos grandes mestres da literatura russa moderna foi, em 1958, agraciado com o Prêmio Nobel de Literatura, o qual por questões políticas foi obrigado a recusar.

PÚCHKIN, Aleksandr Serguéievitch (1799-1837): nasceu em Moscou em 26 de maio (6 de junho). Filho de Serguéi Lvovitch Púchkin e Nadiejda Ossipovna Hannibal. Considerado o iniciados da literatura russa moderna, imprimiu sua marca em tudo o que se faria depois na Rússia, tanto em verso quanto em prosa. Depois de exílio em Odessa e do confinamento na propriedade da família em Mikháilovskoe volta a viver em São Petersburgo, onde conhece e casa-se com Natália Gontcharova. Púchkin foi morto em duelo com o barão Geroge-Charles D’Anthès em 29 de janeiro de 1837.

PÚCHKINA, Maria Alieksievna (1745-1793): avó materna de Púchkin.

ROGNIEDA E VLADÍMIR: Rognieda foi uma das esposas de Vladímir, fundador do Estado Russo no século X. Princesa de Polatsk (cidade histórica da Bielorrússia), Rognieda rejeita a proposta de casamento de Vladímir, alegando que não se casaria com o filho de uma escrava. Indignado com o insulto, Vladímir invade a cidade e mata o pai e os dois irmãos de Rognieda, 
captura a princesa e se casa com ela. Mais tarde, Rognieda assassina o marido em vingança à morte do pai e, no ano 1000 , suicida-se. 0 casal teve três filhos e uma filha

SKOROPÓDSKI, Pável Petrovitch (1873-1945): general do exército tsarista e hetman contra-revolucionário da Ucrânia de 29 de abril a 14 de dezembro de 1918.

TSVETÁIEV, Andrei Ivanovitch: meio-irmão de Marina Tsvetáieva, segundo filho de Ivan Tsvetáiev com a primeira esposa.

TSVETÁIEVA, Anastassia Ivanovna: irmã mais nova de Marina Tsvetáieva.

TSETÁIEVA, Valiéria Ivanovna: meia-irmã de Marina Tsvetáieva, filha mais velha do pai de Tsvetáieva com a primeira esposa. 


\section{Cronologia da vida e da obra de Marina Tsvetáieva}

1892 - Marina Ivanovna Tsvetáieva nasceu em 26 de setembro (9 de outubro segundo o antigo calendário). Filha de Ivan Vladímirovitch Tsvetáiev e Maria Aleksandrovna Mein, passou os primeiros anos de vida em Moscou.

(Morte de Alexandre III. Ascende ao trono Nicolau II)

1894 - Nasce sua irmã Anastásia Ivanovna Tsvetáieva.

1902 - A mãe contrai tuberculose e a família parte para Nervi, em Gênova.

1903 - Marina Tsvetáieva vai com a irmã para um pensionato em Lausanne. Escreve em francês seus primeiros versos.

1904 - Outro pensionato, dessa vez, em Friburgo, na Alemanha. Tsvetáieva escreve versos em alemão.

(Revolução de 1905)

1905 - A família retorna à Rússia e instala-se primeiro em Ialta, depois em Tarussa, onde a mãe vem a falecer aos 38 anos de idade.

1906 - Na companhia do pai e da irmã, regressa a Moscou, onde matricula-se no liceu. Escreve seu primeiro poema Não ria das novas gerações! (He смейтесь вы над юным поколеньем!)

1908 - Passa o verão na vila de Orlovka. 
1909 - O poeta, tradutor e teórico do simbolismo Ellis ${ }^{195}$ a pede em casamento. Ela recusa. É através dele que Tsvetáieva ingressa nos meios literários moscovitas. Passa as férias em Paris. Na volta, inicia um romance com o tradutor e especialista em Grécia Antiga Vladimir Ottonovitch Nilender, que também a pede em casamento, mas ela novamente declina.

1910 - Marina Tsvetáieva abandona o Liceu. No verão, vai com a irmã para Dresden, na Alemanha. Passa o outono reunindo e organizando seus poemas para um livro. No fim deste ano, publica Álbum da tarde. Os poemas são bem recebidos pela crítica. Conhece o artista e crítico de arte Maksimilian Volóchin, que a introduz nos círculos literários mais renomados de Moscou.

1911 - Viaja para o mar Negro e depois a Koktebel, na Criméia, para a casa de veraneio Volóchin. Lá encontra-se pela primeira vez com Serguéi Efron e reconhece nele o homem de sua vida. Tsvetáieva que é bastante míope deixa de usar óculos.

1912 - Em 27 de janeiro, Marina Tsvetáieva e Serguei Efron se casam. Viajam em lua de mel para Itália, França e Alemanha. Em 5 de setembro, nasce a primeira filha do casal, Ariadna Efron. Tsvetáieva publica o livro de poesias Lanterna Mágica, que ela dedica a Serguei Efron.

1913 - Publica por sua conta Fragmentos de dois livros com poemas que não entraram nas coletâneas anteriores. Em 30 de outubro morre-lhe o pai.

(Primeira Guerra Mundial)

${ }^{195}$ Pseudônimo de Lev Lvovitch Kobylinski. 
1914 - Corresponde-se com Vassíli Rózanov, escritor e estudiosos da obra de Dostoiévski. A leitura dos livros de aforismos de Rózanov influencia o estilo dos diários de Marina Tsvetáieva. A tríade (marido-filha-criação) que equilibrava sua vida não a satisfaz como antes. Assim, a poeta começa a entregar-se a paixões efêmeras, tanto com homens quanto com mulheres. Neste ano, inicia romance com a poeta Sofía Parnok.

1915 - Trabalha no livro Poesia juvenil, que será publicado após a sua morte. Serguei Efron parte para o front como enfermeiro. Marina Tsvetáieva e Sofia Parnok passam a morar juntas.

1916 - Durante uma viagem a São Petersburgo no início do ano, Parnok abandona Tsvetáieva. Novos romances se sucedem, um deles com Ossip Mandelstam, poeta que encontrará no caminho a S. Petersburgo e com o qual se encontrará novamente em fevereiro, já em Moscou. Serguei Efron faz cena de ciúmes, ameaça alistar-se como voluntário no exército. Datam deste ano os ciclos Poesias de Moscou e Poesias a Blok.

(Revolução de Outubro)

1917 - Em 14 de abril, nasce sua segunda filha, Irina. Em setembro vai a Feodóssia [Teodóssia] visitar a irmã, Anastassia Tsvetáieva. Estoura a Revolução e a poeta parte imediatamente para Moscou, a fim de encontrar-se com o marido e as filhas. Tsvetáieva e o marido partem para a Criméia, deixando as filhas aos cuidados das irmãs de Efron. Logo Tsvetáieva retorna a Moscou. Seu marido se alista no Exército Branco e eles perdem totalmente o contato.

(Fim da Primeira Guerra Mundial. Início da Guerra Civil na Rússia) 
1918 - Inicia-se um período de miséria e solidão na vida da poeta. Consegue trabalho no Comissariado Popular da Nacionalidade, mas este dura pouco. Envolve-se com um grupo de atores do teatro Vakhtangov, no interior do qual se estabelece complexas relações hétero e homossexuais. Entre eles, está Sónietchika Holliday, que lhe inspiraria mais tarde o texto em prosa Conto de Sónietchka (1937). Neste ano, escreve a peça teatral O fim de Casanova.

1919 - Marina Tsvetáieva recusa qualquer engajamento, apesar de seu marido lutar ao lado dos brancos. Sozinha com as duas filhas pequenas na Moscou assolada pela fome, a poeta decide deixar as meninas aos cuidados de um abrigo para órfãos. No orfanato, a situação de carência é a mesma. Sua filha mais velha, Ariadna, contrai malária e Tsvetáieva vai buscá-la no orfanato. A doença de Ariadna toma todo o tempo de Tsvetáieva, e ela quase não escreve poemas no período. Escreve a obra em prosa Índices Terrestres.

1920 - No dia 3 de fevereiro, sua filha Irina, que ficara aos cuidados do orfanato, morre de inanição. Contudo, Marina Tsvetáieva só tomara conhecimento da notícia quatro dias depois, ao encontrar, por acaso, um funcionário do abrigo.

1921 - Publica o primeiro volume de Verstas, dedicado a Anna Akhmátova, com quem, aliás, chega a se corresponder. Em julho, recebe a notícia de que seu marido está vivo e dá início às tentativas de deixar a Rússia.

(Fim da Guerra Civil. Criação da URSS)

1922 - Com a ajuda de amigos, consegue o visto de saída. No dia 11 de maio, embarca com a pequena Ariadna no trem para Berlim, cidade à qual chega 
quatro dias depois. Passado um mês, o marido Serguei Eron vai ao encontro da mulher e da filha. A família permanece em Berlim por três meses, depois muda-se para a Tchecoslováquia. Inicia correspondência com Boris Pasternak. Publica quatro obras em versos: em Moscou, o segundo volume da coletânea Verstas e o poema $O$ tzar-donzela; em Berlim, os ciclos Poesias a Blok e Separação.

1923 - Ariadna é matriculada em regime de internato no Gimnasium Ruske, na Morávia. Tsvetáieva escreve neste ano numerosos poemas líricos e os poemas longos Le gars e Egóruchka, publicados nas coletâneas Psiquê e Ofício, que saem em Berlim. Romance com o poeta Konstantin Rodziévitch, considerada uma das relações mais importantes de sua vida.

1924 - Rompimento com Rodziévitch. Ariadna volta a viver com os pais. Tsvetáieva escreve Poema da montanha e Poema do fim, além da primeira peça, intitulada Ariana, da trilogia mitológica A ira de Afrodite.

1925 - Nasce Gueórgui Efron, em 1 de fevereiro. No segundo semestre deste ano, o projeto de mudar-se para a França vai tomando forma. No dia 31 de outubro, parte com os filhos para Paris, onde se hospeda em um cômodo da casa da amiga e confidente Olga Kolbássina-Tchernova. Sua chegada é anunciada pela imprensa russa de emigração. Pouco tempo depois, Efron chega à França.

1926 - Organiza um sarau literário de grande sucesso: todos os bilhetes são vendidos. Serguei Efron engaja-se no movimento eurasiano. Marina Tsvetáieva viaja a Londres para a leitura de seus poemas em sarau organizado por Dmítri Sviatopólis-Mírski. Publica o ensaio O poeta e a crítica. 
Começam os ataques da crítica dos exilados russos contra a poeta. Em abril, aluga uma casa em Saint Gilles Croiz de Vie, na costa atlântica da Vendéia. Data deste período a aventura epistolar entre Tsvetáieva, Boris Pasternak e Heine Maria Rilke, denominada “Correspondências de Verão". Apesar das dificuldades materiais, a escritora segue produzindo.

1927 - Escreve em memória de Rilke, que morrera em 29 de dezembro do ano anterior, o poema Carta de ano novo. Envolve-se em polêmica com alguns setores dos russos emigrados, que acusam Efron, então editor da revista Verstas, de manter relações com os bolcheviques. Em setembro recebe a visita de sua irmã Anastassia, que à época trabalhava para Maksim Górki e fora visitá-lo em Sorrento, na Itália. Escreve Fedra, a segunda peça da trilogia A ira de Afrodite.

1928 - Em Paris sai o último livro de poesia que a escritora publicou em vida: Depois da Rússia (1922-1925). Maiakóvski visita Paris e Tsvetáieva vai assistir ao recital que o poeta soviético tinha feito no café Voltaire. A força de Maiakóvski impressiona a poeta, que declara publicamente sua admiração.

1929 - Trabalha no ensaio em prosa Natália Gontcharova. Breve estada em bruxelas. A partir de então sua produção será marcada pela escritura de ensaios de caráter lírico e subjetivo.

1930 - Na URSS, Maiakóvski suicida-se. Tsvetáieva compõe versos em sua homenagem. Cresce ainda mais a hostilidade dos russos exilados contra ela.

1931 - Escreve texto em prosa dedicado a Ossip Mandelstam, intitulado História de uma dedicatória. Escreve o ciclo Poesias a Puchkin e o poema longo Ode à marcha a pé. 
1932 - Morte do amigo Maksimilian Volóchin. As condições econômicas tornam-se cada vez mais desesperadoras. Escreve os artigos $O$ poeta $e$ o tempo e $A$ arte à luz da consciência.

1933 - Escreve os ensaios Uma palavra viva sobre uma pessoa viva, em homenagem a Volóchin, e Uma tarde terrestre, dedicado a Mikhail Kuzmin.

1934 - Morre Andrei Biéli e Tsvetáieva escreve em sua homenagem o ensaio Um espírito prisioneiro. Compõem um longo poema, intitulado Poema sobre a família do tsar. Dessa vez, será alvo de ataques dos emigrados russos simpatizantes do bolchevismo. Escreve, ainda, a prosa memorialística $A$ casa do velho Pimene.

1935 - Serguei Efron ingressa formalmente no serviço secreto soviético, engaja-se na organização União pelo repatriamento dos emigrados russos e passa a receber honorários pelos serviços prestados à URSS. A situação econômica da família melhora significativamente. Em junho, ocorre em Paris o Congresso Internacional para a Defesa da Cultura. Entre os escritores da delegação soviética está Pasternak. 0 encontro entre os poetas finalmente acontece, mas em vez do êxtase esperado, Tsvetáieva decepciona-se. Passa as férias com o filho na Cote d'Azur. Escreve os textos em prosa $O$ diabo e Mamãe e a música, além do ciclo de poemas Epitáfio.

1936 - Breve viagem à Bélgica.

1937 - Ariadna regressa a URSS. Depois será a vez de Efron, implicado no assassinato Ignace Reiss, abandonar a França. Nesse meio tempo, Marina Tsvetáieva trabalha em seu projeto sobre A. S. Puchkin. Conclui o ensaio Meu 
Púchkin, escrito durante o segundo semestre de 1936, compõe Púchkin e Pugatchov e finaliza suas traduções de poemas de Púchkin para o francês. 1938 - Muda-se com o filho para o Hotel Innova. Em outubro a Alemanha invade a Bohemia. Escreve Poesias a Bohemia.

1939 - Escreve o ciclo Poemas à Tchecoslováquia. Regressa a URSS. Ariadna é detida pela polícia soviética em 28 de agosto. Efron em 10 de outubro. Sua irmã Anastassia é mandada para um campo de concentração.

1940 - Não encontra domicílio estável e depende de favores de amigos para ter onde morar. Seu único rendimento vem de traduções para o russo de poetas de diversas nacionalidades. Encontra com Anna Akhmátova.

1941 - A URSS entra na Segunda Guerra Mundial e Moscou é evacuada. Tsvetáieva é transferida para Elábuga, onde suicida-se por enforcamento em 11 de agosto. 


\section{Poemas de Púchkin citados em Meu Púchkin ${ }^{196}$}

Al mar

¡Adios; libérrimo elemento!

Contemplo por postera vez

tus olas célicas al viento,

tu hermosura y altivez.

Cual que já triste de un amigo,

como su voz de despedida,

tu imperativo, misto ruído

por vez postera se avencina.

¡Limite ansiado de mi alma!

Por tus orillas en tinieblas

tan a menudo yo vagaba,

atormentado por mi Idea.

Y no amé tu eco acaso,

todo el fragor de tus abismos

y el silencio al acaso,

y el arrebato advenedizo!

La barca fiel Del pescador

que gurdas tu, mar, por, amtojo,

roza el oleaje con valor,

mas desnfrenas tu enojo

y se hunde en banda la mejor.

\footnotetext{
${ }^{196}$ Apresentaremos aqui traduções para o espanhol e o inglês dos poemas curtos, bem como indicações de sítios da internet em que se possa encontrar os poemas longos.
} 
No supe, al fin, abandonar

tu orilla inmóvil, aburrida, mi alegre agradecerte, mar, y por tus crestas orientar mi tan poética huida

Oi tu voz, encadenado, nn vano mi alma se partia: de una pasión quedé encantado y no abandone tu orilla.

No lo lamento. A dónde, es cierto, quisera, indolente, ir?

Un solo punto en tu desierto me admiraría en el vivir.

Es el sepulcro de la gloria...

Reposa, fría en el peñon, aún solemne, la memoria: allá moría Napoleón.

Murió sufriendo sin remedio, Y como el trueno a la tormenta, En pos de él se fue otro genio, Amo de nuestros pensamientos.

La libertad lloró su arte, dejó el genio su aureola. Oh, mar, commueve hoy las olas, el poeta siempre fue fue vate.

Tu imagen fue su distintivo, tu alma lo forjó sensible, igual que tú, hondo y sombrío, también potente e invencible. 
Quedó vacío el mundo... A dónde

me llevarías, mas hermano?

El mismo sino al mundo ronda

doquier, al bien vigila oronda

la monarquía o el tirano.

¡Adiós, pues, mar! No he de alvidarme

de tu espléndida belleza,

y oiré al caer la tarde

tu voz, fragor que embelesa.

Al bosque, a la llanura hosca,

Pleno de ti, me llevo ahora

Tus claroscuros, golfos, rocas

Y el murmullo de tus olas.

1824

(Versão de Carlos Sherman) 
Camino invernal

La luna se abre camino

Entre niebla vaporosa

Y sobre el bosque mohino

Vierte su luz cavilosa.

Por invernal carretera

Vuela una troika veloz,

Y la esquila viajera

Suena con tediosa voz.

En el cantar del cochero

Se oye un algo muy afín:

Ya un desenfreno altanero,

Ya una tristeza sin fin.

Ni una luz, ni una chozuela,

Sólo desamparo y frío,

Y los hitos siempre en vela

En el camino vacío.

La trsiteza me espolea...

Manãna te veré, amada,

Y junto a la chimenea

En ti ponder la mirada.

Cuenta el tiempo la saeta, Medianoche nos ampara:

Aleja a gente indiscreta, Pero nunca nos separa. 
Triste yo me siento, Nina,

El cochero se ha callado,

La esquila suena cansina,

Y la luna se ha ocultado.

1826

(Versão de José Vento Molina) 
Me erigi un monumento milagroso y notable,

$\mathrm{T}$ en el camino recto que al pueblo hacia él le lleva,

No ha de crecer la yerba. Su cúspide indomable

Más que la alta columna de Alejandro se eleva

No moriré del todo. Por la lira mi alma

Pervivirá a mi polvo y escapará a la quieta

Podredumbre. Famoso he der ser mientras sin calma,

Bajo la luna quede al menos un poeta.

Recorrerá mi fama toda la inmensa Rus.

Y no habrá, en cada idioma, quien mi nombre no sepa:

El tilandés, el nieto del eslavo, el tungús

Salvaje, y el kalmuco amigo de la estepa.

Y sere por el pueblo querido en toda edad

Por despertar los Buenos sentimientos dormidos,

Porque en mi crel siglo canté a la Libertad,

Porque implore clemencia por todos los caídos.

Sé dócil al mandato de Dios, oh Musa mía,

No pidas la corona nil as injuries temas.

Elogios o calumnies acepta sin portía,

Y no entres con el tanto en discussion de temas.

1836

(Versão de Kelin y Arconada) 
Spinning storm clouds, rushing storm clouds,

Hazy skies, a hazy night,

And a furtive moon that slyly

Sets the flying snow alight.

On we drive... The waste is boundless,

Nameless plains skim past, and hills.

Gripped by fear, I sit unmoving...

Tink-tink-tinkle go the bells.

"Coachman, come, wake up!.." "The horses

They are weary, sir, and slow;

As for me, I'm nearly blinded

By this blasted wind and snow!

There's no road in sight, so help me;

What to do?.. We've lost our way.

It's the demon that has got us

And is leading us astray.

"Look! He's close; he plays and teases,

Blows and spits, and, all unseen,

With a laugh our horses pushes

To the edge of a ravine.

Now he'll rise, a giant milepost,

Straight before me; now, a spark,

Flash and gleam, and, sinking, vanish

Of a sudden in the dark."

Spinning storm clouds, rushing storm clouds,

Hazy skies, a hazy night,

And a furtive moon that slyly

Sets the flying snow alight.

Spent from circling round, the horses

Jerk and stop... The bells go dead. 
"That a stump or wolf?" "Yer Honour,

I don't rightly see ahead."

Loud the snowstorm weeps and rages,

And the horses snort in fright.

O'er the plain the demon prances,

In the murk his eyes glow bright.

Off the horses start a'shudder,

And the bells go ting-a-ling...

Demons, demons without number

Gather round us in a ring.

In the eerie play of moonlight

They grimace, they wail and call,

Whirling, leaping, dancing madly

Like the windswept leaves of fall.

Why are they so wild, so restless?

Why so weird the sounds they make?

Could this be a witch's wedding?

Could this be a goblin's wake?

Spinning storm clouds, rushing storm clouds,

Hazy skies, a hazy night,

And a furtive moon that slyly

Sets the flying snow alight.

Skyward soar the whirling demons,

Shrouded by the falling snow,

And their plaintive, awful howling

Fills my heart with dread and woe.

1830

(Translated by Natacha Bulachova) 
To My Nanny

Dear doting sweetheart of my childhood,

Companion of my austere fate!

In the lone house deep in the wild wood

How patiently for me you wait.

Alone beside your window sitting

You wait for me and blame the clock,

While, in your wrinkled hands, your knitting

Fitfully falters to a stop.

Beyond the crumbling gates the pinetrees

Shadow the road you watch so well.

Nameless forebodings, dark anxieties,

Oppress your heart. You cannot tell

What visions haunt you: Now you seem to see...

1826

(Translated by Avril Pyman) 


\section{Drowned}

Children run into their izba,

Hail their father, drip with sweat:

"Daddy, Daddy! Come - there is a

Deadman caught inside our net."

"Scary, scary fabrication,"

Grumbled back the weary $\mathrm{Pa}$,

"Oh these imps' imagination...

Deadman, really: ya-ha-ha!

Hmm... the court may come to bother;

What'll I say before the judge?..

Hey you brats, go have your mother

Bring my coat; I'd better trudge...

So, where is he?" - "There, Dad, farther!"

On the sand where dragnet ropes

Lay spread out, the children's father

Saw a veritable corpse.

Badly mangled, ugly, frightening,

Blue and swollen on each side -

Has he fished in storm and lightning

Or committed suicide?

Could this be a careless drunkard

Or a mermaid-seeking monk

Or a trusting merchant, conquered

By some bandits, robbed and sunk?

To the peasant, what's it matter?

Quick: he grabs the dead man's hair,

Drags the body to the water,

Looks around: nobody there:

Good; relieved of the concern he

Grabbed a paddle, gave a toss,

And the stiff resumed his journey

Downstream for a grave and cross.

Long the dead man as one living 
Rolled on waves amid the foam.

Having watched his gradual leaving,

Our glum peasant started home.

"Come you pups! let's go, don't scatter.

Each of you will get his bun.

But remember: just you chatter -

And I'll whip you, every one."

Dark and stormy it was turning.

High the river ran in gloom.

Now the torch has finished burning

In the peasant's smoky room.

Kids asleep, the wife aslumber,

He lies listening to the rain...

Bang! he hears a sudden comer

Knocking on the windowpane.

"Yeah?" - "Hey, let me in there, master!"

"Cain, you found the time to roam!

Well, what is it, your disaster?

Let you in? It's dark at home,

Dark and crowded... What a pest you are!

Where'd I put you in my cot?.."

Finally with lazy gesture

He lifts up the pane - and what?

Out of clouds the moon was showing.

Well, a naked man was there,

Water down his beard a-flowing,

Wide the eyes, unmoved the stare.

Wholly numb the dreadful body,

Arms were hanging, feeble, thin;

Crabs and cancers, black and bloody,

Sucked into the swollen skin.

And the peasant slammed the shutter:

Recognized his visitant,

Horror-struck he could but mutter

"May you burst!" and start to pant. 
He was shivering, awful chaos

All night through stirred in his brain,

While the knocking shook the house

By the gates and at the pane.

Folks relate a frightful rumor:

Ever since, each year they say

The poor peasant, out of humor,

Waits a visitor that day.

Early on, the storm's increasing,

Nightfall brings a hurricane,

And the drowned man knocks, unceasing,

By the gates and at the pane.

1835

(Translated by Genia Gurarie) 
- O livro Eugene Onegin, A Novel in verse, uma tradução comentada para o inglês de Vladimir Nabukov do romance em versos de Púchkin, assim como outras obras do poeta, pode ser lido online no endereço:

www.books.google.com.br

- Evguénie Oniéguin, Os ciganos e Poltava em inglês:

http://www.pushkininenglish.com/translate.htm 